\title{
Recent Updates in Experimental Research and Clinical Evaluation on Drugs for COVID-19 Treatment
}

\author{
Houwen Zou ${ }^{1 \dagger}$, Yuqi Yang ${ }^{2 \dagger}$, Huiqiang Dai ${ }^{3}$, Yunchuang Xiong ${ }^{3}$, Jing-Quan Wang ${ }^{2}$, \\ Lusheng Lin $^{3 *}$ and Zhe-Sheng Chen ${ }^{2 *}$ \\ ${ }^{1}$ Ganzhou Cancer Hospital, Ganzhou, China, ${ }^{2}$ Department of Pharmaceutical Sciences, College of Pharmacy and Health \\ Sciences, St. John's University, Queens, NY, United States, ${ }^{3}$ Cell Research Center, Shenzhen Bolun Institute of Biotechnology, \\ Shenzhen, China
}

\section{OPEN ACCESS}

Edited by:

Stephen Rennard,

University of Nebraska Medical

Center, United States

Reviewed by:

Ji-Ye Yin,

Central South University, China

Hongtao Xiao,

University of Electronic Science and

Technology of China, China

Yitao Wang,

University of Macau, China

*Correspondence:

Zhe-Sheng Chen

chenz@stjohns.edu

Lusheng Lin

boluninstitute@hczygroup.com

${ }^{t}$ These authors contribute equally to the work.

Specialty section:

This article was submitted to Respiratory Pharmacology, a section of the journal

Frontiers in Pharmacology

Received: 13 July 2021 Accepted: 13 October 2021 Published: 22 November 2021

Citation:

Zou H, Yang Y, Dai H, Xiong Y, Wang J-Q, Lin L and Chen Z-S (2021)

Recent Updates in Experimental Research and Clinical Evaluation on

Drugs for COVID-19 Treatment.

Front. Pharmacol. 12:732403.

doi: 10.3389/fphar.2021.732403
Since the outbreak of corona virus disease 2019 (COVID-19) in Wuhan (China) in December 2019, the epidemic has rapidly spread to many countries around the world, posing a huge threat to global public health. In response to the pandemic, a number of clinical studies have been initiated to evaluate the effect of various treatments against COVID-19, combining medical strategies and clinical trial data from around the globe. Herein, we summarize the clinical evaluation about the drugs mentioned in this review for COVID-19 treatment. This review discusses the recent data regarding the efficacy of various treatments in COVID-19 patients, to control and prevent the outbreak.

Keywords: corona virus disease 2019, corona virus disease 2019 treatment, severe acute respiratory syndrome corona virus 2 variants, antimicrobials, immunotherapy, traditional Chinese medicine

\section{INTRODUCTION}

The outbreak of corona virus disease 2019 (COVID-19), from Wuhan, Hubei Province, China, in December 2019, has now become the first global pandemic caused by the spread of coronavirus. On February 11, 2020, the World Health Organization (WHO) gave a name for the novel coronavirus as severe acute respiratory syndrome coronavirus 2 (SARS-CoV-2) and the coronavirus disease of 2019 (COVID-19) caused by SARS-CoV-2 (Bevova et al., 2020). Most recently, several predominate SARS-CoV-2 variants, including, but not limited to, B.1.1.7 (alpha) variant, B.1.351 (beta) variant, P.1 (gamma), and B.1.617.2 (delta) variant, were first detected in the United Kingdom, South Africa, Brazil, and India, and became a novel global concern (Ong et al., 2021; Sanches et al., 2021). The SARS-CoV-2 variants have greater ability of virus infectivity and immune escape, suggesting that the SARS-CoV-2 variants may result in poor treatment efficacy and prognosis for COVID-19 patients. In the past few months, many research teams from around the world have been conducting in vitro and in vivo studies of the virus, seeking effective prevention and control measures to prevent its spread. China is relatively fast and effective in the control of epidemic. We are, therefore, able to comprehensively analyze common domestic treatment methods and combined domestic and foreign research to jointly explore effective treatment programs for COVID-19, to provide guidance for the second wave of the epidemic.

Many products including, but not limited to, traditional Chinese medicines (TCMs), antiviral drugs (e.g., chloroquine phosphate and alpha-interferon) (Wang and Zhu, 2020), monoclonal antibodies (e.g., tozumab combined with adamumab) (Sarkar et al., 2020), convalescence plasma, and mesenchymal stem cells (MSCs) (Peng et al., 2020) have become the focus of our communication for COVID-19 treatment. The Chinese Clinical Trial Registry (ChiCTR) shows a large number of TCM-related drugs studied for the treatment and prevention of COVID-19 (e.g., Lianhuaqingwen 

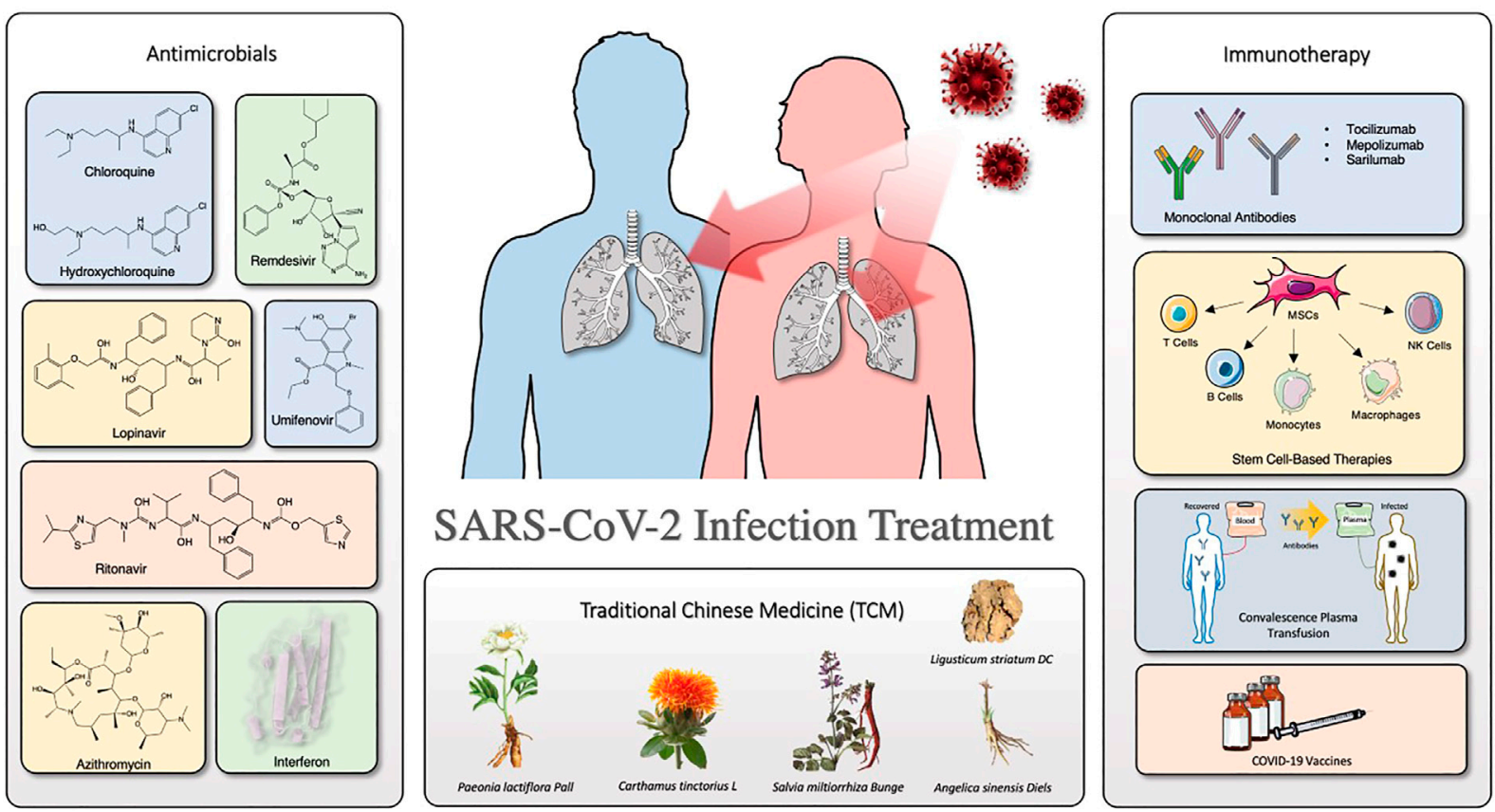

FIGURE 1 | Overview of the organization of this review.

capsule, Shuanghuanglian oral liquid, Xuebijing injection, etc.) (Li H. et al., 2020), while Western drugs focus on antiviral drugs and immunotherapy (e.g., stem cell-based therapy, antibodies, etc.) (Ni et al., 2020a; Gulati et al., 2021). In the Diagnosis and Treatment Protocol for Novel Coronavirus Pneumonia (Trial Version 7), it mentioned several antiviral drugs such as chloroquine (CQ), alpha-interferon (IFN- $\alpha$ ), lopinavir/ ritonavir, and umifenovir, and also mentioned immunotherapy, such as tocilizumab (Wei, 2020a; Zhao et al., 2020a; Wei, 2020b). Notably, as the adage, "old drug, new trick," most of the antiviral drugs used for COVID-19 treatment are existing compounds screened for potential use based on mechanistic similarities to other viruses.

Herein, we summarize the clinical evaluation for COVID-19 treatment about the drugs mentioned in this review. Figure 1 depicts the overview of the organization of this review. Furthermore, we discuss recent representative progresses and considerations in the treatment for COVID-19, especially antimicrobials (antivirals and antibiotics/antibacterial), immunotherapy, and TCMs.

\section{ANTIMICROBIALS}

\section{Chloroquine and hydroxychloroquine}

As a widely used antimalarial and immunomodulatory drug, chloroquine (CQ) shows a broad-spectrum antiviral activity. Table 1 summarizes the clinical trials of CQ and HCQ for the treatment of COVID-19. Some researchers indicated that CQ is effective against SARS-CoV-2 virus in early clinical studies (Huang et al., 2020c). Of note, chloroquine phosphate is undergoing some clinical trials regarding prophylactic use in health personnel (Clinicaltrials.gov, NCT04443270) and against infection by SARS-CoV-2 (Clinicaltrials.gov, NCT04344951). Evidence from a multicenter prospective observational study indicated that patients in CQ treatment group have shorter median time to achieve an undetectable viral RNA and shorter duration of fever; also, more importantly, no severe side effects were found during CQ treatment (Huang et al., 2020b). Hydroxychloroquine (HCQ) is an analog of CQ by replacing an ethyl group in CQ with a hydroxyethyl group (Zhou et al., 1878). Nowadays, ChiCTR conducts many clinical trials in China to examine the effectiveness and safety of CQ or HCQ against COVID-19 (Gao et al., 2020). A team from Renmin Hospital of Wuhan University investigated the effects of HCQ among 62 patients suffering from COVID-19 (www.chictr.org.cn, ChiCTR2000029559). As a result, Chen et al. found that HCQ could significantly shorten time to clinical recovery (TTCR) and improve pneumonia.

However, the high-quality clinical data showing a clear and reliable benefit of CQ or HCQ remains limited. Also, the CQ or HCQ treatment could induce severe cardiac side effects, imped innate and adaptive antiviral immune responses, and cause some uncertain effects (Meyerowitz et al., 2020). Commonly, QT prolongation and torsade de Pointes (TdP) occur on patients who are administered with CQ or HCQ (Blignaut et al., 2019). Hence, before CQ and HCQ treatment, an initial cardiac evaluation is necessary for COVID-19 patients (Zhou W. et al., 2020). Also, several follow-up evaluations, such as regular ophthalmological examination and cardiac monitor, are suggested for patients with short- or long-term treatment (Knox and Owens, 1966). Thus, using CQ or HCQ as a 
TABLE 1 | Summary of clinical trials of chloroquine (CQ) and hydroxychloroquine (HCQ) on COVID-19 treatment.

\begin{tabular}{|c|c|c|c|c|c|c|}
\hline Trial title & Sponsor & $\begin{array}{c}\text { Trial } \\
\text { phase }\end{array}$ & Primary intervention & $\begin{array}{l}\text { Secondary } \\
\text { intervention }\end{array}$ & Status & Identifier \\
\hline $\begin{array}{l}\text { Efficacy of Chloroquine or } \\
\text { Hydroxychloroquine in } \\
\text { COVID-19 Treatment }\end{array}$ & Tanta University & $\|/\| \|$ & $\begin{array}{l}\text { Chloroquine or } \\
\text { hydroxychloroquine }\end{array}$ & $\mathrm{N} / \mathrm{A}$ & Recruiting & NCT04353336 \\
\hline $\begin{array}{l}\text { Chloroquine for Mild } \\
\text { Symptomatic and } \\
\text { Asymptomatic COVID-19 }\end{array}$ & $\begin{array}{l}\text { HaEmek Medical Center, } \\
\text { Israel }\end{array}$ & $\|/\| \|$ & Chloroquine & Standard care & $\begin{array}{l}\text { Terminated (Terminated } \\
\text { due to changes in } \\
\text { treatment guidelines.) }\end{array}$ & NCT04333628 \\
\hline $\begin{array}{l}\text { Zinc With Chloroquine/ } \\
\text { Hydroxychloroquine in } \\
\text { Treatment of COVID-19 }\end{array}$ & Tanta University & III & Chloroquine & Chloroquine + zinc tablets & Recruiting & NCT04447534 \\
\hline $\begin{array}{l}\text { The Vietnam Chloroquine } \\
\text { Treatment on COVID-19 } \\
\text { (VICO) }\end{array}$ & $\begin{array}{l}\text { Oxford University Clinical } \\
\text { Research Unit, Vietnam }\end{array}$ & $\|$ & $\begin{array}{l}\text { Chloroquine } \\
\text { phosphate }\end{array}$ & $\mathrm{N} / \mathrm{A}$ & Recruiting & NCT04328493 \\
\hline $\begin{array}{l}\text { Chloroquine + Losartan } \\
\text { Compared to Chloroquine } \\
\text { Alone for the Treatment of } \\
\text { COVID-19 Pneumonia }\end{array}$ & $\begin{array}{l}\text { Hospital Universitario Dr. } \\
\text { Jose E. Gonzalez }\end{array}$ & $\|$ & $\begin{array}{l}\text { Chloroquine } \\
\text { phosphate }\end{array}$ & Chloroquine + losartan & $\begin{array}{l}\text { Withdrawn (Evidence } \\
\text { showed chloroquine is not } \\
\text { effective against } \\
\text { COVID-19.) }\end{array}$ & NCT04428268 \\
\hline $\begin{array}{l}\text { Chloroquine Phosphate } \\
\text { Prophylactic Use in Health } \\
\text { Personnel Exposed to } \\
\text { COVID-19 Patients }\end{array}$ & CMN "20 de Noviembre" & l & $\begin{array}{l}\text { Chloroquine } \\
\text { phosphate }\end{array}$ & N/A & Not yet recruiting & NCT04443270 \\
\hline Prevention with & Fundacion Clinica Valle & $\|$ & Chloroquine & $\mathrm{N} / \mathrm{A}$ & Active, not recruiting & NCT04627467 \\
\hline
\end{tabular}

Chloroquine in Health

Personnel Exposed to Infection with Coronavirus Disease 2019 (COVID-19) (TS-COVID) (TS-COVID)

Chloroquine Phosphate Against Infection by the Novel Coronavirus SARSCoV-2 (COVID-19): The HOPE Open-Label, NonRandomized Clinical Trial (HOPE)

Chloroquine Outpatient Treatment Evaluation for HIV-COVID-19 (CQOTE)

Chloroquine as Antiviral

Treatment in Coronavirus Infection 2020

Chloroquine,

Hydroxychloroquine or Only Supportive Care in Patients Admitted With Moderate to Severe COVID-19 (ARCHAIC)

Chloroquine Diphosphate in the Prevention of SARS in COVID-19 Infection (CloroCOVID19II) Efficacy of Chloroquine or Hydroxychloroquine in Treating Pneumonia del Lili

Chloroquine

NCT04627467

Uni-Pharma Kleon Tsetis

I Chloroquine

N/A

Recruiting

NCT04344951

Pharmaceutical

Laboratories S.A.

University of Cape Town

Wroclaw Medical

University

UMC Utrecht

Fundação de Medicina

Tropical Dr. Heitor Vieira

Dourado

Centro de Estudos e

Pesquisa em

Emergencias medicase

Terapia Intensiva

Columbia University

Government of Punjab, Specialized Healthcare and Medical Education Department
COVID-19

Saved From COVID-19

Prophylaxis of Exposed COVID-19 Individuals With Mild Symptoms Using Chloroquine Compounds (PRECISE) 
TABLE 1 | (Continued) Summary of clinical trials of chloroquine (CQ) and hydroxychloroquine (HCQ) on COVID-19 treatment.

\begin{tabular}{|c|c|c|c|c|c|c|}
\hline Trial title & Sponsor & $\begin{array}{c}\text { Trial } \\
\text { phase }\end{array}$ & Primary intervention & $\begin{array}{l}\text { Secondary } \\
\text { intervention }\end{array}$ & Status & Identifier \\
\hline $\begin{array}{l}\text { The Clinical Study of } \\
\text { Carrimycin on Treatment } \\
\text { Patients With COVID-19 }\end{array}$ & Beijing YouAn Hospital & IV & Carrimycin & $\begin{array}{l}\text { Chloroquine phosphate or } \\
\text { lopinavir/ritonavir tablets or } \\
\text { arbidol }\end{array}$ & Not yet recruiting & NCT04286503 \\
\hline $\begin{array}{l}\text { Post-Exposure Prophylaxis } \\
\text { for Asymptomatic SARS- } \\
\text { CoV-2 COVID-19 Patients }\end{array}$ & $\begin{array}{l}\text { Government of Punjab, } \\
\text { Specialized Healthcare } \\
\text { and Medical Education }\end{array}$ & IV & $\begin{array}{l}\text { Chloroquine or } \\
\text { hydroxychloroquine }\end{array}$ & Standard of care + placebo & Terminated (Poor accrual.) & NCT04346667 \\
\hline
\end{tabular}

CoV-2 COVID-19 Patients

Department

Compounds (PEA

Immune Monitoring of

Prophylactic Effect of

Hydroxychloroquine in

Healthcare Providers Highly

Exposed to COVID-19

(Chloroquine UN)

Angiotensin Converting

Enzyme Inhibitors in

Treatment of Covid 19

Evaluation of Efficacy of

Levamisole and Formoterol

+ Budesonide in Treatment

of COVID-19

Austrian CoronaVirus

Adaptive Clinical Trial

(COVID-19) (ACOVACT)

An Adaptive Study of

Favipiravir Compared to

Standard of Care in

Hospitalized Patients With

COVID-19

Efficacy of Natural Honey

Treatment in Patients With

Novel Coronavirus

Study of Favipiravir

Compared to Standard of

Care in Hospitalized

Patients With COVID-19

Hydroxychloroquine for

Treatment of Non-Severe

COVID-19 (HONEST)

Efficacy and Safety of Anti

HCV Drugs in the

Treatment of COVID-19

Hydroxychloroquine as

Post Exposure Prophylaxis

for SARS-CoV-2(HOPE

Trial)

PATCH 2 and 3: Prevention

and Treatment of COVID-

19 (Severe Acute

Respiratory Syndrome

Coronavirus 2) With

Hydroxychloroquine

Efficacy of Azithromycin-

Associated

Hydroxychloroquine

Therapy Given in General
Universidad Nacional de

Colombia

Tanta University

Fasa University of

Medical Sciences

Medical University of

Vienna

Chromis LLC

Science and Technology

Promomed, LLC

III Favipiravir

Makerere University

Cairo University

Gangnam Severance

Hospital

United Health Group

II

Hydroxychloroquine

Placebo drug

II

Publique-Hôpitaux de

Paris

III

Captopril or enalapril Chloroquine

budesonide +

formoterol inhaler

Chloroquine or hydroxychloroquine care

Chloroquine,

Chloroquine,

I Hydroxychloroquine tablets

sofosbuvir/daclatasvir

Hydroxychloroquine

N/A

azithromycin
Placebo oral tablet

Withdrawn (The study did not get financed. Never got started.)

Hydroxychloroquine + lopinavir/ritonavir

Lopinavir/ritonavir; Standard Recruiting hydroxychloroquine, lopinavir/ritonavir, etc.

Chloroquine phosphate or hydroxychloroquine or lopinavir/ritonavir tablets or arbidol or oseltamivir with or without azithromycin

hydroxychloroquine,

lopinavir/ritonaviretc.

Standard care only

Hydroxychloroquine

Not yet recruiting

Terminated (As enrollment began, external studies called into question the safety and efficacy of hydroxychloroquine as a treatment, which resulted in controversy. The timing of the controversy significantly impacted our ability to enroll and retain participants.)

Withdrawn (Regulatory approvals have not been obtained.)
NCT04330144

NCT04346329

NCT04345406

NCT04331470

NCT04351724

NCT04434248

NCT04323345

NCT04542694

NCT04860284

NCT04443725

NCT04353037

NCT04371406

(Continued on following page) 
TABLE 1 | (Continued) Summary of clinical trials of chloroquine (CQ) and hydroxychloroquine (HCQ) on COVID-19 treatment.

Trial title

Sponsor

Trial Primary intervention

Secondary

intervention

Status

Identifier

Practice in Early-Stage

Disease in COVID-19

Patients (MG-COVID)

Evaluation of the Efficacy of University Hospital,

the Hydroxychloroquine-

Azithromycin Combination

in the Prevention of COVID-

19 Related Sdra

(Teachcovid)

Safety and Efficacy of

Hydroxychloroquine

Associated With

Azithromycin in SARS-

CoV2 Virus (Coalition

COVID-19 Brasil II)

Hydroxychloroquine for the University Hospital

Treatment of Mild COVID- Tuebingen

19 Disease (COMIHY)

\section{Strasbourg, France}

Hospital Israelita Albert

Einstein
III Hydroxychloroquine and azithromycin

Hydroxychloroquine; IV antibiotics and standard of care

III Hydroxychloroquine + Hydroxychloroquine azithromycin

II Hydroxychloroquine Placebo capsules

III Hydroxychloroquine Placebo capsules sulfate

III Hydroxychloroquine

University Hospital,

Angers

Placebo in COVID-19

Patients at Risk for Severe

Disease (HYCOVID)

Hydroxychloroquine and

Ivermectin for the

Treatment of COVID-19

Infection

Assessing

Hydroxychloroquine in

Patients With SARS-CoV-2

(COVID-19)

Healthcare Worker

Exposure Response and

Outcomes of

Hydroxychloroquine

(HERO-HCQ)

Favipiravir in Hospitalized

COVID-19 Patients (FIC)

Hydroxychloroquine and

lopinavir/ritonavir to

Improve the Health of

People With COVID-19:

"The Hope Coalition - 1"

Chemoprophylaxis of

SARS-CoV-2 Infection

(COVID-19) in Exposed

Healthcare Workers

(COVIDAXIS)

Azithromycin in

Hospitalized COVID-19

Patients (AIC)
Centenario Hospital

Miguel Hidalgo

Oregon Health and

Science University

Adrian Hernandez

Shahid Beheshti

University of Medical

Sciences

Cardresearch

Centre Hospitalier

Universitaire de Saint

Etienne

Shahid Beheshti

University of Medical

Sciences
III Hydroxychloroquine sulfate tablets

III Hydroxychloroquine oral tablet

IV Hydroxychloroquine
IV Favipiravir

Lopinavir/ritonavir oral

(All information in the table are collected from https://clinicaltrials.gov).

Withdrawn (In view of the

notices concerning

hydroxychloroquine issued

by the regulatory

authorities, we withdraw

the protocol.)

Completed
NCT04321278

NCT04347512

NCT04321278

(n)

Placebo

\author{
Terminated (It appeared to \\ be impossible for the study \\ lefts to recruit the targeted \\ number of patients, due to \\ reduced incidence and \\ reduced acceptance \\ to IMP.) \\ Terminated (Reduced \\ acceptance of IMP.) \\ Terminated (Decrease in \\ number of eligible patients.) \\ NCT04325893
}

Completed

NCT04391127

Withdrawn (Discontinued in favor of more promising directions that may benefit patients.)

Completed

NCT04334148

NCT04363866

(Compled

Not yet recruiting

NCT04359615

Hydroxychloroquine

Lopinavir/ritonavir oral

Recruiting

NCT04403100

tablet; placebo

tablet; placebo

Active, not recruiting

NCT04328285

Active, not recriting

Not yet recruiting

NCT04359316
COVID-19 treatment was controversial, which results from their ocular, cardiac, and neuro toxicities (Oren et al., 2020; Zou et al., 2020). Additionally, the certainty of evidence is low.
Together, we would like to recommend monitoring the accumulative effect of long-term and/or high-dose CQ or HCQ in clinical settings. Also, researchers are not supposed 
TABLE 2 | Summary of clinical trials of lopinavir/ritonavir on COVID-19 treatment.

\begin{tabular}{|c|c|c|c|c|c|c|}
\hline Trial title & Sponsor & $\begin{array}{c}\text { Trial } \\
\text { phase }\end{array}$ & Primary intervention & $\begin{array}{l}\text { Secondary } \\
\text { intervention }\end{array}$ & Status & Identifier \\
\hline $\begin{array}{l}\text { Comparison of Lopinavir/ } \\
\text { Ritonavir or } \\
\text { Hydroxychloroquine in Patients } \\
\text { With Mild Coronavirus Disease } \\
\text { (COVID-19) }\end{array}$ & $\begin{array}{l}\text { Asan Medical } \\
\text { Center }\end{array}$ & $\|$ & Lopinavir/ritonavir tablet & $\begin{array}{l}\text { Hydroxychloroquine sulfate } \\
\text { tablet }\end{array}$ & $\begin{array}{l}\text { Terminated } \\
\text { (Terminated early } \\
\text { because no patients } \\
\text { were further enrolled } \\
\text { since mid-Apr 2020.) }\end{array}$ & NCT04307693 \\
\hline $\begin{array}{l}\text { COVID-19 Ring-based } \\
\text { Prevention Trial With Lopinavir/ } \\
\text { Ritonavir (CORIPREV-LR) }\end{array}$ & Darrell Tan & III & Lopinavir/ritonavir & N/A & Recruiting & NCT04321174 \\
\hline $\begin{array}{l}\text { Lopinavir/Ritonavir for the } \\
\text { Treatment of COVID-19 } \\
\text { Positive Patients With Cancer } \\
\text { and Immune Suppression in } \\
\text { the Last Year }\end{array}$ & $\begin{array}{l}\text { OHSU Knight } \\
\text { Cancer Institute }\end{array}$ & $\|$ & Lopinavir/ritonavir & Placebo & $\begin{array}{l}\text { Withdrawn (Limited } \\
\text { resources.) }\end{array}$ & NCT04455958 \\
\hline $\begin{array}{l}\text { FLARE: Favipiravir } \pm \text { Lopinavir: } \\
\text { A RCT of Early Antivirals } \\
\text { (FLARE) }\end{array}$ & $\begin{array}{l}\text { University College, } \\
\text { London }\end{array}$ & $\|$ & Favipiravir & Lopinavir/ritonavir; placebo & Recruiting & NCT04499677 \\
\hline $\begin{array}{l}\text { Trial of Early Therapies During } \\
\text { Non-Hospitalized Outpatient } \\
\text { Window for COVID-19 } \\
\text { (TREATNOW) }\end{array}$ & $\begin{array}{l}\text { Vanderbilt University } \\
\text { Medical Center }\end{array}$ & $\|$ & Lopinavir/ritonavir tablets & Placebo & Recruiting & NCT04372628 \\
\hline $\begin{array}{l}\text { Combination Therapies to } \\
\text { Reduce Carriage of SARS- } \\
\text { Cov-2 and Improve Outcome } \\
\text { of COVID-19 in Ivory Coast: A } \\
\text { phase Randomized Ilb Trial } \\
\text { (INTENSE-COV) }\end{array}$ & $\begin{array}{l}\text { ANRS, Emerging } \\
\text { Infectious Diseases }\end{array}$ & $\|/\| \|$ & Lopinavir/ritonavir & $\begin{array}{l}\text { Lopinavir/ritonavir + telmisartan; } \\
\text { lopinavir/ritonavir + atorvastatin }\end{array}$ & Recruiting & NCT04466241 \\
\hline $\begin{array}{l}\text { Comparative Therapeutic } \\
\text { Efficacy and Safety of Different } \\
\text { Antiviral and Anti-Inflammatory } \\
\text { Drugs in COVID-19 Patients }\end{array}$ & October 6 University & IV & $\begin{array}{l}\text { Remdesivir + tocilizumab + } \\
\text { lopinavir/ritonavir }\end{array}$ & $\begin{array}{l}\text { Hydroxychloroquine + } \\
\text { tocilizumab + ivermectin }\end{array}$ & Recruiting & NCT04779047 \\
\hline $\begin{array}{l}\text { Evaluation of Additional } \\
\text { Treatments for COVID-19: A } \\
\text { Randomized Trial in Niger } \\
\text { (TRASCOV) }\end{array}$ & Epicentre & III & $\begin{array}{l}\text { Standard care + lopinavir/ } \\
\text { ritonavir }\end{array}$ & Standard care & $\begin{array}{l}\text { Withdrawn } \\
\text { (Epidemic } \\
\text { dynamics.) }\end{array}$ & NCT04409483 \\
\hline $\begin{array}{l}\text { Baricitinib Therapy in } \\
\text { COVID-19 }\end{array}$ & Fabrizio Cantini & $\|/\|$ & Lopinavir/ritonavir tablets & N/A & Completed & NCT04358614 \\
\hline $\begin{array}{l}\text { Efficacy of Pragmatic Same- } \\
\text { Day COVID-19 Ring } \\
\text { Prophylaxis for Adult } \\
\text { Individuals Exposed to SARS- } \\
\text { CoV-2 in Switzerland (COPEP) }\end{array}$ & Calmy Alexandra & III & Lopinavir/ritonavir & N/A & Completed & NCT04364022 \\
\hline $\begin{array}{l}\text { Baricitinib in Symptomatic } \\
\text { Patients Infected by COVID-19: } \\
\text { An Open-Label, Pilot Study } \\
\text { (BARI-COVID) }\end{array}$ & Hospital of Prato & $\|/\|$ & Lopinavir/ritonavir & $\begin{array}{l}\text { Antiviral and/or } \\
\text { hydroxychloroquine }\end{array}$ & Not yet recruiting & NCT04320277 \\
\hline $\begin{array}{l}\text { Preventing Pulmonary } \\
\text { Complications in Surgical } \\
\text { Patients at Risk of COVID-19 } \\
\text { (PROTECT-Surg) }\end{array}$ & $\begin{array}{l}\text { University of } \\
\text { Birmingham }\end{array}$ & III & Lopinavir/ritonavir & $\begin{array}{l}\text { Hydroxychloroquine; lopinavir/ } \\
\text { ritonavir + hydroxychloroquine }\end{array}$ & Not yet recruiting & NCT04386070 \\
\hline $\begin{array}{l}\text { Trial of Treatments for COVID- } \\
19 \text { in Hospitalized Adults } \\
\text { (DisCoVeRy) }\end{array}$ & $\begin{array}{l}\text { Institut National de } \\
\text { la Santé Et de la } \\
\text { Recherche } \\
\text { Médicale, France }\end{array}$ & III & Lopinavir/ritonavir & $\begin{array}{l}\text { Lopinavir/ritonavir + interferon } \\
\beta-1 a ; \text { remdesivir; } \\
\text { hydroxychloroquine; standard } \\
\text { care; placebo }\end{array}$ & Active, not recruiting & NCT04315948 \\
\hline $\begin{array}{l}\text { Treatment for COVID-19 in } \\
\text { High-Risk Adult Outpatients }\end{array}$ & $\begin{array}{l}\text { University of } \\
\text { Washington }\end{array}$ & $\|/ I\|$ & Lopinavir/ritonavir & $\begin{array}{l}\text { Hydroxychloroquine + folic } \\
\text { acid; hydroxychloroquine + } \\
\text { azithromycin }\end{array}$ & Active, not recruiting & NCT04354428 \\
\hline $\begin{array}{l}\text { Randomized Evaluation of } \\
\text { COVID-19 Therapy } \\
\text { (RECOVERY) }\end{array}$ & University of Oxford & $\|/\| \|$ & Lopinavir/ritonavir & $\begin{array}{l}\text { Corticosteroid; } \\
\text { hydroxychloroquine; } \\
\text { azithromycin; convalescent } \\
\text { plasma; tocilizumab; } \\
\text { immunoglobulin; synthetic } \\
\text { neutralizing antibodies; aspirin; } \\
\text { colchicine; baricitinib; anakinra; } \\
\text { dimethyl fumarate; infliximab }\end{array}$ & Recruiting & NCT04366089 \\
\hline
\end{tabular}


TABLE 2 | (Continued) Summary of clinical trials of lopinavir/ritonavir on COVID-19 treatment.

\begin{tabular}{|c|c|c|c|c|c|c|}
\hline Trial title & Sponsor & $\begin{array}{c}\text { Trial } \\
\text { phase }\end{array}$ & Primary intervention & $\begin{array}{l}\text { Secondary } \\
\text { intervention }\end{array}$ & Status & Identifier \\
\hline $\begin{array}{l}\text { A Study of Combination } \\
\text { Therapies to Treat COVID-19 } \\
\text { Infection }\end{array}$ & ProgenaBiome & $\|$ & $\begin{array}{l}\text { Hydroxychloroquine + } \\
\text { lopinavir/ritonavir, + } \\
\text { azithromycin }\end{array}$ & $\begin{array}{l}\text { Hydroxychloroquine + } \\
\text { azithromycin }\end{array}$ & $\begin{array}{l}\text { Withdrawn (Was } \\
\text { never started.) }\end{array}$ & NCT04459702 \\
\hline $\begin{array}{l}\text { Isotretinoin in Treatment of } \\
\text { COVID-19 (Randomized) }\end{array}$ & Tanta University & III & Isotretinoin & $\begin{array}{l}\text { Paracetamol, } \\
\text { hydroxychloroquine, } \\
\text { oseltamivir, azithromycin or } \\
\text { clarithromycin ascorbic acid } \\
\text { and cyanocobalamin plus } \\
\text { lopinavir/ritonavir with or } \\
\text { without isotretinoin }\end{array}$ & Not yet recruiting & NCT04361422 \\
\hline $\begin{array}{l}\text { P2Et Extract in the } \\
\text { Symptomatic Treatment of } \\
\text { Subjects With COVID-19 }\end{array}$ & $\begin{array}{l}\text { Hospital } \\
\text { Universitario San } \\
\text { lgnacio }\end{array}$ & $\|/\| \|$ & $\begin{array}{l}\text { Lopinavir/ritonavir, } \\
\text { hydroxychloroquine, } \\
\text { Caesalpinia spinosa } \\
\text { extract capsule }\end{array}$ & Placebo & Recruiting & NCT04410510 \\
\hline
\end{tabular}

(All information in the table are collected from https://clinicaltrials.gov).

to overstate or understate the clinical efficacy of CQ and HCQ on COVID-19 treatment.

\section{Lopinavir/ritonavir}

Lopinavir/ritonavir tablets (brand name: Kaletra) are two structurally related protease inhibitors and works as antiretroviral agents (Cvetkovic and Goa, 2003). Table 2 summarizes the clinical trials of lopinavir/ritonavir on COVID-19 treatment. The mechanism of action of protease inhibitors is block cleavage in Gag and Gag-Pol, and result in producing immature and noninfectious virus particles (Adamson, 2012). Similar to CQ, lopinavir/ritonavir could act as potential antiviral agents against SARS in vitro and in patients with SARS infection (Chu et al., 2004). Also, lopinavir/ritonavir has favorable clinical outcome with the Middle East respiratory syndrome coronavirus (MERS-CoV) after MERS reported in 2012 (Mo and Fisher, 2016; Arabi et al., 2018). Evidence from randomized trials indicated that lopinavir/ritonavir might improve outcomes in severe and critical COVID-19 patients, but it may induce mortality (Verdugo-Paiva et al., 2020). Moreover, it is reported that lopinavir/ritonavir could only improve a minority of throat-swab nucleic acid results in hospitals (Liu et al., 2020). Also, Cao et al. revealed that no beneficial response or clinical improvement was observed after treatment with lopinavir/ritonavir in a randomized, controlled, open-label trial with 199 in hospital patients suffering from severe SARS-CoV-2 infection, even though improvement was found for some secondary endpoints (Cao et al., 2020; Stower, 2020). Together, the response of COVID-19 patients with lopinavir/ ritonavir is not ideal and unfavorable. As the previous study showed, CQ had more potent effects to patients with COVID-19 than the use of lopinavir/ritonavir; hence, an ongoing clinical trial in China would like to access the effectiveness and safety of CQ and lopinavir/ritonavir for patients suffering from mild or general SARS-CoV-2 infection (www.chictr.org.cn, ChiCTR2000029741). Overall, available data on the anti-SARS-
CoV-2 activity of lopinavir/ritonavir are still limited and investigational, thereby the clinical application of lopinavir/ ritonavir should be considered and monitored carefully.

\section{Remdesivir}

Remdesivir (GS-5734, brand name: Veklury), as a nucleotide analog prodrug, is a broad-spectrum antiviral drug that acts on RNA-dependent RNA polymerase (RdRp) and results in premature termination (Tchesnokov et al., 2019; Lamb, 2020). Table 3 shows the summary of clinical trials of remdesivir on COVID-19 treatment. As previously mentioned, Wang et al. showed that the $\mathrm{EC}_{50}$ value of remdesivir is $1.76 \mu \mathrm{M}$ in Vero E6 cells, which suggests that remdesivir has high effectiveness in the control of SARS-CoV-2 infection in vitro (Wang M. et al., 2020). More importantly, the intravenous remdesivir was administrated to the patient who was the first case diagnosed as SARS-CoV-2 infection in the United States (Holshue et al., 2020). No adverse effects were observed in association with the infusion; also, clinical benefits were found in patients. Another case demonstrated that remdesivir could accelerate recovery time by 4 days, which is a meaningful and optimistic progress for patients and medical systems (Jorgensen et al., 2020). Notably, remdesivir is FDA approved specifically for the treatment of COVID-19. However, as more and more clinical cases were reported, the outcome of remdesivir treatment sometimes cannot achieve the expected effects on COVID-19 patients. Many researchers (Wang Y. et al., 2020) carried out a randomized, double-blind, placebo-controlled, multicenter trial; as a result, Wang et al. found that remdesivir is not associated with statistically significant clinical improvement, even though some patients in the remdesivir treatment group had numerically faster time to improve than those in the placebo group. More importantly, remdesivir treatment was discontinued early due to the adverse events, including, but not limited to, nausea, constipation, and respiratory failure or acute respiratory distress. Overall, the certainty of evidence remains less. Since 
TABLE 3 | Summary of clinical trials of remdesivir on COVID-19 treatment.

\begin{tabular}{|c|c|c|c|c|c|c|}
\hline Trial title & Sponsor & $\begin{array}{c}\text { Trial } \\
\text { phase }\end{array}$ & $\begin{array}{c}\text { Primary } \\
\text { intervention }\end{array}$ & $\begin{array}{l}\text { Secondary } \\
\text { intervention }\end{array}$ & Status & Identifier \\
\hline $\begin{array}{l}\text { Study to Evaluate the Safety, } \\
\text { Tolerability, } \\
\text { Pharmacokinetics, and } \\
\text { Efficacy of Remdesivir (GS- } \\
5734^{\mathrm{TM}} \text { ) in Participants From } \\
\text { Birth to <18 Years of Age With } \\
\text { Coronavirus Disease } 2019 \\
\text { (COVID-19) (CARAVAN) }\end{array}$ & Gilead Sciences & $\|/\| \|$ & Remdesivir & $\mathrm{N} / \mathrm{A}$ & Recruiting & NCT04431453 \\
\hline $\begin{array}{l}\text { Remdesivir Efficacy in } \\
\text { Coronavirus Disease }\end{array}$ & Tanta University & $\|/\| I$ & Remdesivir & Standard of care & Recruiting & NCT04345419 \\
\hline Study in Participants With & Gilead Sciences & I/II & Remdesivir & Placebo & Completed & NCT04539262 \\
\hline
\end{tabular}

Early-Stage Coronavirus

Disease 2019 (COVID-19) to

Evaluate the Safety, Efficacy, and Pharmacokinetics of Remdesivir Administered by Inhalation

A Trial of Remdesivir in Adults With Severe COVID-19

Capital Medical

University

A Trial of Remdesivir in Adults With Mild and Moderate

COVID-19

Comparison of Remdesivir

Versus Lopinavir/Ritonavir

and Remdesivir Combination

in COVID-19 Patients

Efficacy and Safety of

DWJ1248 With remdesivir in

Severe COVID-19 Patients

Efficacy and Safety of

Remdesivir and Tociluzumab

for the Management of Severe

COVID-19: A Randomized

Controlled Trial

REMdesivir-HU Clinical Study and Severe Covid-19 Patients

Study to Evaluate the Safety and Antiviral Activity of

Remdesivir (GS-5734 ${ }^{\mathrm{TM}}$ ) in

Participants With Severe

Coronavirus Disease

(COVID-19)

Study to Evaluate the Safety

and Antiviral Activity of

Remdesivir (GS-5734 ${ }^{\mathrm{TM}}$ ) in

Participants With Moderate

Coronavirus Disease (COVID-

19) Compared to Standard of

Care Treatment

Study to Evaluate the Efficacy and Safety of remdesivir in

Participants With Severely

Reduced Kidney Function

Who Are Hospitalized for

Coronavirus Disease 2019

(COVID-19) (REDPINE)

Study of Merimepodib in

Combination With Remdesivir

University

Ahmed Essam

Daewoong

Pharmaceutical

Co. LTD.

Hospital
Capital Medical

IV

M Abdur Rahim

Medical College and

\section{University of Pecs}

Gilead Sciences

Gilead Sciences

Remdesivir

Standard of care

Placebo

Recruiting
Remdesivir

NCT04257656 of COVID-19 has been controlled well in China; no eligible patients can be enrolled at present.)

Suspended (The epidemic NCT04252664 of COVID-19 has been controlled well at present; no eligible patients can be recruited.)

Lopinavir/ritonavir + remdesivir Recruiting

NCT04738045

Recruiting

NCT04713176

DWJ1248

Remdesivir + tocilizumab

N/A

Completed

NCT04678739

Active, not recruiting

NCT04610541

Completed

NCT04292899
ViralClear

Pharmaceuticals, Inc Merimepodib +
remdesivir
Placebo + remdesivir
Terminated (Failure to meet primary endpoint)
NCT04292730

(Continued on following page) 
TABLE 3 | (Continued) Summary of clinical trials of remdesivir on COVID-19 treatment.

\begin{tabular}{|c|c|c|c|c|c|c|}
\hline Trial title & Sponsor & $\begin{array}{c}\text { Trial } \\
\text { phase }\end{array}$ & $\begin{array}{c}\text { Primary } \\
\text { intervention }\end{array}$ & $\begin{array}{l}\text { Secondary } \\
\text { intervention }\end{array}$ & Status & Identifier \\
\hline
\end{tabular}

in Adult Patients With

Advanced COVID-19

Remdesivir Efficacy in

Management of COVID-19

Patients

A Study to Evaluate the

Efficacy and Safety of

Remdesivir Plus tocilizumab

Compared With remdesivir

Plus Placebo in Hospitalized

Participants With Severe

COVID-19 Pneumonia

(REMDACTA)

Study to Evaluate the Efficacy and Safety of remdesivir (GS-

$5734^{\mathrm{TM}}$ ) Treatment of

Coronavirus Disease 2019

(COVID-19) in an Outpatient

Setting

Safety, Tolerability and

Pharmacokinetics of Inhaled

Nanoparticle Formulation of

Remdesivir (GS-5734) and

NA-831 (Neurosivir)

GS-5734 to Assess the

Antiviral Activity, Longer-Term

Clearance of Ebola Virus, and

Safety in Male Ebola Survivors

With Evidence of Ebola Virus

Persistence in Semen

Factorial Randomized Trial of

Rendesivir and Baricitinib Plus

Dexamethasone for COVID-

19 (the AMMURAVID Trial)

(AMMURAVID)

Treatments for COVID-19:

Canadian Arm of the

SOLIDARITY Trial (CATCO)

Efficacy of Ramdicivir and

Baricitinib for the Treatment of

Severe COVID 19 Patients

Adaptive COVID-19

Treatment Trial 2 (ACTT-2)

The Efficacy of Different Anti-

Viral Drugs in COVID 19

Infected Patients

World Health Organization

(WHO) COVID-19 Solidarity

Trial for COVID-19

Treatments (SOLIDARITY)

ACTIV-5/Big Effect Trial (BET-

A) for the Treatment of

COVID-19

Ain Shams University

III Remdesivir

Hoffmann-La Roche

Remdesivir + tocilizumab

Gilead Sciences

III Remdesivir

Placebo

Active, not recruiting

NCT04501952

NeuroActiva, Inc

I Remdesivir

NA-831; NA-831 + remdesivir Recruiting

NCT04480333

National Institute of

॥ Remdesivir

Placebo

Completed

NCT02818582

Allergy and Infectious

Diseases (NIAID)

ASST Fatebenefratelli

Sunnybrook Health

M Abdur Rahim

Medical College and

Hospital

National Institute of

Allergy and Infectious

Diseases (NIAID)

Oslo University

Hospital

The University of The

West Indies

II/III Remdesivir

National Institute of

Allergy and Infectious

Diseases (NIAID)

ACTIV-5/Big Effect Trial (BET- National Institute of

B) for the Treatment of

COVID-19

Adaptive COVID-19

Treatment Trial 4 (ACTT-4)

National Institute of Allergy

and Infectious Diseases

(NIAID)
Allergy and Infectious Diseases (NIAID)

National Institute of

Allergy and Infectious

Diseases (NIAID)

Adaptive COVID-19

Treatment Trial (ACTT)
III

Remdesivir +

dexamethasone

II

Remdesivir +

standard supportive

care

III

Remdesivir +

baricitinib

III Remdesivir + baricitinib

III Remdesivir

Baricitinib + dexamethasone; Not yet recruiting

NCT04832880 remdesivir + baricitinib + dexamethasone

Interferon $\beta-1 \mathrm{a}+$ standard

Recruiting

NCT04330690

supportive care

Remdesivir + tocilizumab

Recruiting

NCT04693026

Remdesivir + placebo

Completed

NCT04401579

Hydroxychloroquine

Recruiting

NCT04321616

Acalabrutinib; interferon $\beta$-1a Not yet recruiting

NCT04647669

II Remdesivir + risankizumab

॥ Remdesivir + lenzilumab

III Remdesivir + baricitinib

III Remdesivir
Remdesivir + placebo

Remdesivir + placebo

Remdesivir + dexamethasone

Placebo
Recruiting

Recruiting

Active, not recruiting

Completed
NCT04583956

NCT04583969

NCT04640168

NCT04280705

(Continued on following page) 
TABLE 3 | (Continued) Summary of clinical trials of remdesivir on COVID-19 treatment.

\begin{tabular}{|c|c|c|c|c|c|c|}
\hline Trial title & Sponsor & $\begin{array}{c}\text { Trial } \\
\text { phase }\end{array}$ & $\begin{array}{c}\text { Primary } \\
\text { intervention }\end{array}$ & $\begin{array}{l}\text { Secondary } \\
\text { intervention }\end{array}$ & Status & Identifier \\
\hline $\begin{array}{l}\text { An International Randomized } \\
\text { Trial of Additional Treatments } \\
\text { for COVID-19 in Hospitalized } \\
\text { Patients Who Are All } \\
\text { Receiving the Local Standard } \\
\text { of Care-WHO- } \\
\text { SOLIDARITY-GERMANY }\end{array}$ & $\begin{array}{l}\text { Professor Dr. Bernd } \\
\text { Mühlbauer }\end{array}$ & $\|/\| \|$ & $\begin{array}{l}\text { Remdesivir }+ \\
\text { standard of care }\end{array}$ & Standard of care & Active, not recruiting & NCT04575064 \\
\hline $\begin{array}{l}\text { Efficacy of favipiravir in } \\
\text { Treatment of Mild and } \\
\text { Moderate COVID-19 Infection } \\
\text { in Nepal }\end{array}$ & $\begin{array}{l}\text { Nepal Health } \\
\text { Research Council }\end{array}$ & III & Favipiravir + placebo & Remdesivir & Recruiting & NCT04694612 \\
\hline $\begin{array}{l}\text { Inpatient Treatment With Anti- } \\
\text { Coronavirus Immunoglobulin } \\
\text { (ITAC) }\end{array}$ & $\begin{array}{l}\text { University of } \\
\text { Minnesota }\end{array}$ & III & $\begin{array}{l}\text { Hyperimmune } \\
\text { immunoglobulin to } \\
\text { SARS-CoV-2 (hIVIG) } \\
\text { + remdesivir }\end{array}$ & Placebo + remdesivir & Active, not recruiting & NCT04546581 \\
\hline $\begin{array}{l}\text { Immune Modulators for } \\
\text { Treating COVID-19 (ACTIV- } \\
1 \text { IM) }\end{array}$ & Daniel Benjamin & III & $\begin{array}{l}\text { Remdesivir }+ \\
\text { infliximab or matching } \\
\text { placebo }\end{array}$ & $\begin{array}{l}\text { Remdesivir + abatacept or } \\
\text { matching placebo; remdesivir } \\
\text { + cenicriviroc or matching } \\
\text { placebo }\end{array}$ & Recruiting & NCT04593940 \\
\hline $\begin{array}{l}\text { COVID-19 and Anti-CD14 } \\
\text { Treatment Trial (CaTT) }\end{array}$ & $\begin{array}{l}\text { National Institute of } \\
\text { Allergy and Infectious } \\
\text { Diseases (NIAID) }\end{array}$ & $\|$ & $\begin{array}{l}\text { Remdesivir + anti- } \\
\text { CD14 }\end{array}$ & Remdesivir + placebo & Recruiting & NCT04391309 \\
\hline $\begin{array}{l}\text { Aralast NP With Antiviral } \\
\text { Treatment and Standard of } \\
\text { Care Versus Antiviral } \\
\text { Treatment With Standard of } \\
\text { Care in Hospitalized Patients } \\
\text { With Pneumonia and COVID- } \\
19 \text { Infection }\end{array}$ & $\begin{array}{l}\text { Blessing Corporate } \\
\text { Services, Inc. }\end{array}$ & III & $\begin{array}{l}\text { Remdesivir + alpha1- } \\
\text { proteinase inhibitor }\end{array}$ & Remdesivir & $\begin{array}{l}\text { Withdrawn (Administrative } \\
\text { Decision) }\end{array}$ & NCT04675086 \\
\hline $\begin{array}{l}\text { First-in-Human Study of Orally } \\
\text { Administered GS-441524 for } \\
\text { COVID-19 }\end{array}$ & $\begin{array}{l}\text { Copycat } \\
\text { Sciences LLC }\end{array}$ & 1 & Remdesivir & N/A & Active, not recruiting & NCT04859244 \\
\hline $\begin{array}{l}\text { Trial to Determine the } \\
\text { Efficacy/Safety of Plitidepsin } \\
\text { vs Control in Patients With } \\
\text { Moderate COVID-19 Infection } \\
\text { (Neptuno) }\end{array}$ & PharmaMar & III & $\begin{array}{l}\text { Plitidepsin + } \\
\text { dexamethasone }\end{array}$ & Remdesivir + dexamethasone & Not yet recruiting & NCT04784559 \\
\hline $\begin{array}{l}\text { I-SPY COVID-19 TRIAL: An } \\
\text { Adaptive Platform Trial for } \\
\text { Critically III Patients } \\
\text { (I-SPY_COVID) }\end{array}$ & $\begin{array}{l}\text { QuantumLeap } \\
\text { Healthcare } \\
\text { Collaborative }\end{array}$ & $\|$ & Remdesivir & $\begin{array}{l}\text { Remdesivir + cenicriviroc; } \\
\text { remdesivir + icatibant; } \\
\text { remdesivir + pulmozyme; } \\
\text { remdesivir + IC14; remdesivir } \\
\text { + celecoxib and famotidine; } \\
\text { remdesivir + narsoplimab }\end{array}$ & Recruiting & NCT04488081 \\
\hline $\begin{array}{l}\text { ACTIV-3b: Therapeutics for } \\
\text { Severely III Inpatients With } \\
\text { COVID-19 (TESICO) }\end{array}$ & $\begin{array}{l}\text { National Institute of } \\
\text { Allergy and Infectious } \\
\text { Diseases (NIAID) }\end{array}$ & III & Aviptadil + remdesivir & $\begin{array}{l}\text { Aviptadil + placebo; placebo + } \\
\text { remdesivir; placebo }\end{array}$ & Recruiting & NCT04843761 \\
\hline $\begin{array}{l}\text { ACTIV-3: Therapeutics for } \\
\text { Inpatients With COVID-19 } \\
\text { (TICO) }\end{array}$ & $\begin{array}{l}\text { National Institute of } \\
\text { Allergy and Infectious } \\
\text { Diseases (NIAID) }\end{array}$ & III & Remdesivir & $\begin{array}{l}\text { LY3819253; VIR-7831; BRII- } \\
\text { 196/BRII-198; AZD7442; } \\
\text { placebo }\end{array}$ & Recruiting & NCT04501978 \\
\hline
\end{tabular}

(All information in the table are collected from https://clinicaltrials.gov).

Nov. 2020, the WHO has issued a conditional recommendation against the use of remdesivir in COVID-19 patients.

\section{Interferons}

The interferons (IFNs) as glycoproteins have broad-spectrum antiviral effects (Lin and Young, 2014). The IFNs can be divided into three types based on the differences in the structures of their respective receptors. In detail, the IFNs are classified into type I IFNs (IFN- $\alpha / \beta$ ), type II IFNs (IFN- $\gamma$ ), and type III IFNs (IFN- $\lambda$ ). Table 4 shows the summary of clinical trials of IFNs on COVID-19 treatment. Mantlo et al. (2020) demonstrated that IFN- $\alpha$ $\left(\mathrm{EC}_{50}=1.35 \mathrm{IU} / \mathrm{ml}\right)$ and IFN $\beta\left(\mathrm{EC}_{50}=0.76 \mathrm{IU} / \mathrm{ml}\right)$ at clinically achievable concentrations could suppress the replication of SARC-CoV-2 in Vero cells. These findings provide a valuable fundamental for the potential use of IFN- $\alpha / \beta$ to against COVID19. Zhou et al. accessed the efficacy of IFN- $\alpha 2 b$ and arbidol involving 77 hospitalized patients; as a result, researchers revealed that IFN$a 2 b$ with or without arbidol could significantly reduce the duration for detectable virus as well as the inflammatory markers (Zhou Q. et al., 2020). Usually, the IFNs are used in combination with other 
TABLE 4 | Summary of clinical trials of interferons (IFNs) on COVID-19 treatment.

\begin{tabular}{|c|c|c|c|c|c|c|}
\hline Trial title & Sponsor & $\begin{array}{c}\text { Trial } \\
\text { phase }\end{array}$ & Primary intervention & $\begin{array}{l}\text { Secondary } \\
\text { intervention }\end{array}$ & Status & Identifier \\
\hline $\begin{array}{l}\text { Double Therapy With IFN-beta } \\
1 \mathrm{~b} \text { and Hydroxychloroquine }\end{array}$ & $\begin{array}{l}\text { The University of } \\
\text { Hong Kong }\end{array}$ & $\|$ & $\begin{array}{l}\text { Interferon } \beta-1 b+ \\
\text { hydroxychloroquine }\end{array}$ & Hydroxychloroquine & Completed & NCT04350281 \\
\hline $\begin{array}{l}\text { Pegylated Interferon Lambda } \\
\text { Treatment for COVID-19 }\end{array}$ & Raymond Chung & $\|$ & Interferon $\lambda$ & Placebo & Enrolling by invitation & NCT04343976 \\
\hline $\begin{array}{l}\text { Pegylated Interferon - a2b With } \\
\text { SARSCoV- } 2 \text { (COVID-19) }\end{array}$ & $\begin{array}{l}\text { Cadila Healthcare } \\
\text { Limited }\end{array}$ & $\|$ & Interferon $a-2 b$ & Standard of Care & Recruiting & NCT04480138 \\
\hline $\begin{array}{l}\text { Interferon Beta 1a in } \\
\text { Hospitalized COVID-19 } \\
\text { Patients (IB1alC) }\end{array}$ & $\begin{array}{l}\text { Shahid Beheshti } \\
\text { University of Medical } \\
\text { Sciences }\end{array}$ & IV & $\begin{array}{l}\text { Interferon } \beta \text {-1a + lopinavir/ } \\
\text { ritonavir }+ \text { single dose of } \\
\text { hydroxychloroquine }\end{array}$ & $\begin{array}{l}\text { Lopinavir/ritonavir + single } \\
\text { dose of hydroxychloroquine }\end{array}$ & Enrolling by invitation & NCT04350671 \\
\hline $\begin{array}{l}\text { Dual Therapy With Interferon } \\
\text { Beta-1b and Clofazimine for } \\
\text { COVID-19 }\end{array}$ & $\begin{array}{l}\text { The University of } \\
\text { Hong Kong }\end{array}$ & $\|$ & $\begin{array}{l}\text { Interferon } \beta-1 b+ \\
\text { clofazimine }\end{array}$ & Clofazimine & Recruiting & NCT04465695 \\
\hline $\begin{array}{l}\text { The Investigation Into } \\
\text { Beneficial Effects of High-Dose } \\
\text { Interferon Beta 1-a, Compared } \\
\text { to Low-dose Interferon Beta 1- } \\
\text { a in Moderate to Severe } \\
\text { Covid-19 }\end{array}$ & $\begin{array}{l}\text { Shahid Beheshti } \\
\text { University of Medical } \\
\text { Sciences }\end{array}$ & $\|$ & $\begin{array}{l}\text { Lopinavir/ritonavir }+ \text { high } \\
\text { dose interferon } \beta-1 a\end{array}$ & $\begin{array}{l}\text { Lopinavir/ritonavir }+ \text { low } \\
\text { dose interferon } \beta \text {-1a }\end{array}$ & Not yet recruiting & NCT04521400 \\
\hline $\begin{array}{l}\text { An Investigation into Beneficial } \\
\text { Effects of Interferon Beta 1a, } \\
\text { Compared to Interferon Beta } \\
1 \mathrm{~b} \text { and the base Therapeutic } \\
\text { Regiment in Moderate to } \\
\text { Severe COVID-19: A } \\
\text { Randomized Clinical Trial } \\
\text { (COVIFERON) }\end{array}$ & $\begin{array}{l}\text { Shahid Beheshti } \\
\text { University of Medical } \\
\text { Sciences }\end{array}$ & $\|$ & $\begin{array}{l}\text { Hydroxychloroquine }+ \\
\text { lopinavir/ritonavir }+ \\
\text { interferon } \beta \text {-1a }\end{array}$ & $\begin{array}{l}\text { Hydroxychloroquine + } \\
\text { lopinavir/ritonavir + interferon } \\
\beta-1 b ; \text { hydroxychloroquine + } \\
\text { lopinavir/ritonavir }\end{array}$ & Completed & NCT04343768 \\
\hline $\begin{array}{l}\text { Clinical Study for the } \\
\text { Treatment With Interferon-ß- } \\
\text { 1a (IFNß-1a) of COVID-19 } \\
\text { Patients (INTERCOP) }\end{array}$ & Emanuele Bosi & $\|$ & Interferon $\beta$-1a & Standard care & Terminated (Futility.) & NCT04449380 \\
\hline $\begin{array}{l}\text { Treatment of COVID-19 by } \\
\text { Nebulization of Interferon Beta } \\
1 \text { b Efficiency and Safety Study } \\
\text { (COV-NI) }\end{array}$ & $\begin{array}{l}\text { Centre Hospitalier } \\
\text { Universitaire, Amiens }\end{array}$ & $\|$ & $\begin{array}{l}\text { Type I interferon + routine } \\
\text { care }\end{array}$ & Routine care & Recruiting & NCT04469491 \\
\hline $\begin{array}{l}\text { Interferon Lambda for } \\
\text { Immediate Antiviral Therapy at } \\
\text { Diagnosis in COVID-19 (ILIAD) }\end{array}$ & $\begin{array}{l}\text { University Health } \\
\text { Network, Toronto }\end{array}$ & $\|$ & Interferon $\lambda-1 a$ & Placebo & Recruiting & NCT04354259 \\
\hline $\begin{array}{l}\text { Pegylated Interferon Lambda } \\
\text { for Treatment of COVID-19 } \\
\text { Infection }\end{array}$ & $\begin{array}{l}\text { Soroka University } \\
\text { Medical Center }\end{array}$ & $\|$ & $\begin{array}{l}\text { Interferon } \lambda+\text { standard of } \\
\text { care treatment }\end{array}$ & Standard of care treatment & Recruiting & NCT04534673 \\
\hline $\begin{array}{l}\text { IFN-Beta } 1 \mathrm{~b} \text { and Remdesivir } \\
\text { for COVID19 }\end{array}$ & $\begin{array}{l}\text { The University of } \\
\text { Hong Kong }\end{array}$ & $\|$ & $\begin{array}{l}\text { Interferon } \beta-1 b+ \\
\text { remdesivir }\end{array}$ & Remdesivir & Recruiting & NCT04647695 \\
\hline $\begin{array}{l}\text { The Containing Coronavirus } \\
\text { Disease } 19 \text { (COVID-19) Trial } \\
\text { (ConCorD-19) }\end{array}$ & $\begin{array}{l}\text { Pontificia Universidad } \\
\text { Catolica de Chile }\end{array}$ & III & Interferon $\beta$-1a & Standard of care & Recruiting & NCT04552379 \\
\hline $\begin{array}{l}\text { Human Intravenous Interferon } \\
\text { Beta-la Safety and Preliminary } \\
\text { Efficacy in Hospitalized } \\
\text { Subjects With CoronavirUS } \\
\text { (HIBISCUS) }\end{array}$ & $\begin{array}{l}\text { Faron } \\
\text { Pharmaceuticals Ltd. }\end{array}$ & $\|$ & Interferon $\beta$-1a & Placebo & Not yet recruiting & NCT04860518 \\
\hline $\begin{array}{l}\text { Rintatolimod and IFN Alpha-2b } \\
\text { for the Treatment of Mild or } \\
\text { Moderate COVID-19 Infection } \\
\text { in Cancer Patients }\end{array}$ & $\begin{array}{l}\text { Roswell Park Cancer } \\
\text { Institute }\end{array}$ & $|/| \mid$ & $\begin{array}{l}\text { Recombinant interferon } \\
a-2 b+\text { rintatolimod }\end{array}$ & Rintatolimod & Recruiting & NCT04379518 \\
\hline $\begin{array}{l}\text { IFN Beta-1b and Ribavirin for } \\
\text { Covid-19 }\end{array}$ & $\begin{array}{l}\text { The University of } \\
\text { Hong Kong }\end{array}$ & $\|$ & $\begin{array}{l}\text { Interferon } \beta-1 \mathrm{~b}+\text { ribavirin } \\
+ \text { standard care }\end{array}$ & Standard care & Recruiting & NCT04494399 \\
\hline $\begin{array}{l}\text { Adaptive COVID-19 Treatment } \\
\text { Trial } 3 \text { (ACTT-3) }\end{array}$ & $\begin{array}{l}\text { National Institute of } \\
\text { Allergy and Infectious } \\
\text { Diseases (NIAID) }\end{array}$ & III & $\begin{array}{l}\text { Remdesivir }+ \\
\text { interferon } \beta \text {-1a }\end{array}$ & Remdesivir + placebo & Completed & NCT04492475 \\
\hline $\begin{array}{l}\text { Interferon Lambda Therapy for } \\
\text { COVID-19 }\end{array}$ & $\begin{array}{l}\text { Icahn School of } \\
\text { Medicine at Mount } \\
\text { Sinai }\end{array}$ & $\|$ & Interferon $\lambda$-1a & Supportive care & $\begin{array}{l}\text { Withdrawn (Due to the } \\
\text { number of competing } \\
\text { trials at their site, the } \\
\text { study team has closed } \\
\text { enrollment and } \\
\text { withdrawn this trial.) } \\
\text { (Continued on } 1\end{array}$ & lowing page) \\
\hline
\end{tabular}


TABLE 4 | (Continued) Summary of clinical trials of interferons (IFNs) on COVID-19 treatment.

\begin{tabular}{|c|c|c|c|c|c|c|}
\hline Trial title & Sponsor & $\begin{array}{c}\text { Trial } \\
\text { phase }\end{array}$ & Primary intervention & $\begin{array}{l}\text { Secondary } \\
\text { intervention }\end{array}$ & Status & Identifier \\
\hline $\begin{array}{l}\text { Evaluation of Ganovo } \\
\text { (Danoprevir) Combined With } \\
\text { Ritonavir in the Treatment of } \\
\text { SARS-CoV-2 Infection }\end{array}$ & $\begin{array}{l}\text { The Ninth Hospital of } \\
\text { Nanchang }\end{array}$ & IV & $\begin{array}{l}\text { Ganovo + ritonavir + } \\
\text { interferon nebulization }\end{array}$ & Ganovo + ritonavir & Completed & NCT04291729 \\
\hline $\begin{array}{l}\text { COVID-19 Prevention and } \\
\text { Treatment in Cancer; a } \\
\text { Sequential Multiple } \\
\text { Assignment Randomized Trial; } \\
\text { (C-SMART) }\end{array}$ & $\begin{array}{l}\text { Peter MacCallum } \\
\text { Cancer Centre, } \\
\text { Australia }\end{array}$ & III & Interferon a & Selinexor; lenzilumab & Recruiting & NCT04534725 \\
\hline $\begin{array}{l}\text { An Open-Label Study to } \\
\text { Assess Response to COVID- } \\
19 \text { Vaccine in Multiple } \\
\text { Sclerosis Participants Treated } \\
\text { With ofatumumab }\end{array}$ & $\begin{array}{l}\text { Novartis } \\
\text { Pharmaceuticals }\end{array}$ & IV & $\begin{array}{l}\text { Ofatumumab + mRNA } \\
\text { COVID-19 vaccine }\end{array}$ & $\begin{array}{l}\text { Interferon or glatiramer } \\
\text { acetate + mRNA COVID-19 } \\
\text { vaccine }\end{array}$ & Not yet recruiting & NCT04878211 \\
\hline $\begin{array}{l}\text { Trial of COVID-19 Outpatient } \\
\text { Treatment in Individuals With } \\
\text { Risk Factors for Aggravation } \\
\text { (COVERAGEFrance) }\end{array}$ & $\begin{array}{l}\text { University Hospital, } \\
\text { Bordeaux }\end{array}$ & $\|/\| \|$ & Interferon $\beta-1 b$ & $\begin{array}{l}\text { Telmisartan; ciclesonide; } \\
\text { vitamins }\end{array}$ & Recruiting & NCT04356495 \\
\hline $\begin{array}{l}\text { Anti-Coronavirus Therapies to } \\
\text { Prevent Progression of } \\
\text { Coronavirus Disease } 2019 \\
\text { (COVID-19) Trial } \\
\text { (ACTCOVID19) }\end{array}$ & $\begin{array}{l}\text { Population Health } \\
\text { Research Institute }\end{array}$ & III & Interferon $\beta$ & $\begin{array}{l}\text { Colchicine; aspirin; } \\
\text { rivaroxaban; usual care }\end{array}$ & Recruiting & NCT04324463 \\
\hline $\begin{array}{l}\text { Peginterferon Lambda-1a for } \\
\text { the Prevention and Treatment } \\
\text { of SARS-CoV-2 (COVID-19) } \\
\text { Infection (PROTECT) }\end{array}$ & $\begin{array}{l}\text { Johns Hopkins } \\
\text { University }\end{array}$ & $\|$ & Interferon $\lambda$-1a & Placebo & $\begin{array}{l}\text { Terminated (Single left } \\
\text { study with low } \\
\text { enrollment) }\end{array}$ & NCT04344600 \\
\hline
\end{tabular}

(All information in the table are collected from https://clinicaltrials.gov).

antiviral therapies (Mantlo et al., 2020). Of note, a group from China examined the effectiveness and safety profile of a triple antiviral therapy including IFN- $\beta 1$ b, lopinavir/ritonavir, and ribavirin with 86 patients suffering from mild to moderate SARS-CoV-2 infection (Hung et al., 2020). Their results showed that the triple combination treatment is superior to lopinavir/ritonavir treatment alone with shorter viral shedding duration and hospital stay period.

However, some reports indicated that the application of IFN- $\lambda$ have more advantages in COVID-19 treatment. The most outstanding profile of IFN- $\lambda$ over IFN- $\alpha / \beta$ is the absence of proinflammatory effects (Prokunina-Olsson et al., 2020). This is because the response to IFN- $\lambda$ administration localizes to epithelial cells, which could reduce side effects and inflammatory effects related to the systemic action from IFN- $\alpha / \beta$ treatment. Also, researchers showed that IFN $-\lambda$ reduces the presence of virus in the lungs and prevents the induction of cytokine storm; hence, the application of IFN- $\lambda$ could avoid pneumonia and acute respiratory distress syndrome (ARDS) (Andreakos and Tsiodras, 2020). Overall, IFN- $\lambda$ is a promising and potential therapeutic agent for patients suffering from COVID-19. Notably, more clinical study is necessary in the future.

\section{Umifenovir}

Umifenovir (brand name: Arbidol, ARB) is an antiviral drug, which has the ability to inhibit the replication of influenza $A$ and $B$ virus through impeding the early membrane fusion event
(Leneva et al., 2009). Table 5 indicates the summary of clinical trials of umifenovir for the treatment of COVID-19. Zhu et al. (2020) accessed the efficacy and safety of lopinavir/ ritonavir and umifenovir involving 50 COVID-19 patients, 34 cases with lopinavir/ritonavir treatment, and 16 cases with umifenovir treatment. From the results, no side effects and developed pneumonia or ARDS were observed in both groups. More importantly, patients with umifenovir treatment have shorter duration of positive RNA test compared with those with lopinavir/ritonavir treatment; thus, the authors indicated that umifenovir may be superior to lopinavir/ritonavir against COVID-19. Similarly, Deng et al. (2020) demonstrated that lopinavir/ritonavir combined with umifenovir had more favorable clinical outcomes compared with lopinavir/ritonavir only in a retrospective cohort study. Furthermore, Nojomi et al. (2020) evaluated HCQ followed by lopinavir/ritonavir or HCQ followed by umifenovir among 100 patients with COVID-19. As a result, the researchers found that patients in the umifenovir group had shorter hospitalized duration and higher peripheral oxygen saturation rate, also had improvements in requiring ICU admissions, and chest CT involvement. Moreover, some studies showed that umifenovir was well-tolerated with mild gastrointestinal tract reaction and related to the lower mortality in COVID-19 cases (Jomah et al., 2020).

However, Lian et al. (2020) indicated that umifenovir is not relative to the improved response in non-ICU COVID-19 
TABLE 5 | Summary of clinical trials of umifenovir on COVID-19 treatment.

\begin{tabular}{|c|c|c|c|c|c|c|}
\hline Trial title & Sponsor & $\begin{array}{c}\text { Trial } \\
\text { phase }\end{array}$ & Primary intervention & $\begin{array}{l}\text { Secondary } \\
\text { intervention }\end{array}$ & Status & Identifier \\
\hline $\begin{array}{l}\text { Study of Efficacy and Safety } \\
\text { of TL-FVP-t vs. SOC in } \\
\text { Patients With Mild to } \\
\text { Moderate COVID-19 }\end{array}$ & R-Pharm & III & Favipiravir + stand of care & $\begin{array}{l}\text { Umifenovir + intranasal recombinant } \\
\text { interferon } \alpha \text {, or hydroxychloroquine, or } \\
\text { chloroquine, or mefloquine in } \\
\text { recommended regimen }\end{array}$ & $\begin{array}{l}\text { Active, not } \\
\text { recruiting }\end{array}$ & NCT04501783 \\
\hline $\begin{array}{l}\text { Umifenovir in Hospitalized } \\
\text { COVID-19 Patients (UAIIC) }\end{array}$ & $\begin{array}{l}\text { Shahid Beheshti } \\
\text { University of } \\
\text { Medical } \\
\text { Sciences }\end{array}$ & IV & $\begin{array}{l}\text { Umifenovir }+ \text { interferon } \beta-1 a+ \\
\text { lopinavir/ritonavir }+ \text { single dose of } \\
\text { hydroxychloroquine }+ \text { standards of } \\
\text { care }\end{array}$ & $\begin{array}{l}\text { Interferon } \beta-1 a+\text { lopinavir/ritonavir }+ \\
\text { single dose of hydroxychloroquine }+ \\
\text { standards of care }\end{array}$ & $\begin{array}{l}\text { Enrolling } \\
\text { by } \\
\text { invitation }\end{array}$ & NCT04350684 \\
\hline
\end{tabular}

(All information in the table are collected from https://clinicaltrials.gov).

patients in a retrospective study. In detail, the study included 81 patients suffering from COVID-19, and evaluated several baseline clinical and laboratory factors. Of note, the patients with umifenovir treatment even had longer hospital stay duration than those patients in the control group. Hence, the authors indicated that umifenovir might not improve prognosis or accelerate SARS-CoV-2 clearance in non-ICU patients with COVID-19.

\section{Azithromycin}

Azithromycin is a macrolide antibiotic medication. Azithromycin binds to the $50 \mathrm{~S}$ subunit of ribosome, and thereby prevents the mRNA translation and interferes with protein synthesis (Bakheit et al., 2014). Table 6 summarizes the clinical trials of azithromycin on COVID-19 treatment. Gautret et al. (2020) showed that azithromycin could reinforce the effectiveness of HCQ to clear the COVID-19 virus. Of note, the sample size was small, which only involved 20 cases. Also, researchers revealed that azithromycin combined with HCQ, or with lopinavir/ ritonavir, could improve the clinical response and accelerate the COVID-19 virus clearance (Purwati et al., 2021). By contrast, Cavalcanti et al. (2020) reported that no improved clinical outcomes were observed in COVID-19 patients, suffering from mild to moderate COVID-19, treated with HCQ alone or with azithromycin compared with those with standard care in a multicenter, randomized, open-label, threegroup, controlled trial involving 667 patients. Also, evidence from retrospective observational studies demonstrated that azithromycin in combination with HCQ did not induce favorable clinical outcomes for COVID-19 patients (Echeverría-Esnal et al., 2021).

\section{Antibacterial/antibiotic drugs}

It has been reported that bacterial coinfection happened in $3.5 \%$ of COVID-19 patients (Sieswerda et al., 2021). In other words, the hospitalized patients with COVID-19 have risk of bacterial infections. Sieswerda et al. (2021) recommended that the 5-day antibiotic therapy is required for the COVID-19 patients suffering with suspected bacterial respiratory infection after clinical improvements. However, their recommendation needs to be confirmed because unnecessary antibiotic treatment should be prevented. Also, some studies revealed that bacterial and fungal coinfection would occur in patients with SARS-CoV-2 infection, thereby the antimicrobial treatment regimen and stewardship interventions are necessary to control the exacerbating COVID-19 pandemic (Rawson et al., 2020). More importantly, antimicrobial resistance should be considered as the collateral effect of SARS-CoV-2 infection, and thus, proper trend for antibiotic stewardship interventions should be analyzed and prescribed in the emergency department (Pulia et al., 2020).

\section{IMMUNOTHERAPY}

\section{Monoclonal antibody Tocilizumab}

Tocilizumab (TCZ, trade name: Actemra) is a recombinant humanized monoclonal antibody (Sheppard et al., 2017). TCZ is well-tolerated without significant abnormalities after long-term toxicity tests on animals (Gabay et al., 2013). For the mechanism of action, TCZ specially binds membrane-bound interleukin-6 receptor (mIL-6R) and soluble interleukin-6 receptor (sIL-6R) and inhibits signal transduction (Ibrahim et al., 2020). It has been reported that COVID-19 induces higher plasma levels of cytokines including, but not limited to, IL-6, IL-2, IL-7, IL-10, tumor necrosis factor- $\alpha$ (TNF- $\alpha$ ), IFN- $\gamma$-inducible protein, etc., in ICU patients with SARS-CoV-2 infection (Chen N. et al., 2020; Huang C. et al., 2020), which refers to a cytokine storm in patients. Furthermore, several studies indicated that TCZ treatment could return the temperature to normal quickly and improve the respiratory function through blocking IL-6 receptors (Fu et al., 2020; Zhang et al., 2020). Table 7 shows the clinical trials of TCZ on COVID-19 treatment. Luo et al. (2020) examined the efficacy of TCZ, as a recombinant humanized antihuman IL-6 receptor monoclonal antibody, and found that the serum IL-6 level decreased in 10 patients, while the persistent and dramatic increase in IL-6 was found in four patients who failed in the treatment. In contrast, Xu et al. (2020) recorded the clinical manifestation, computerized tomography (CT) scan image, and laboratory examinations to assess the effectiveness of TCZ in severe COVID-19 patients. Their results showed that TCZ has critical roles in pathogenesis and clinical improvement in patients. Moreover, Klopfenstein et al. (2020) performed a retrospective case-control study involving 20 patients with severe SARS-CoV-2 infection and found that TCZ could reduce the number of ICU admissions and/or mortality 
TABLE 6 | Summary of clinical trials of azithromycin on COVID-19 treatment.

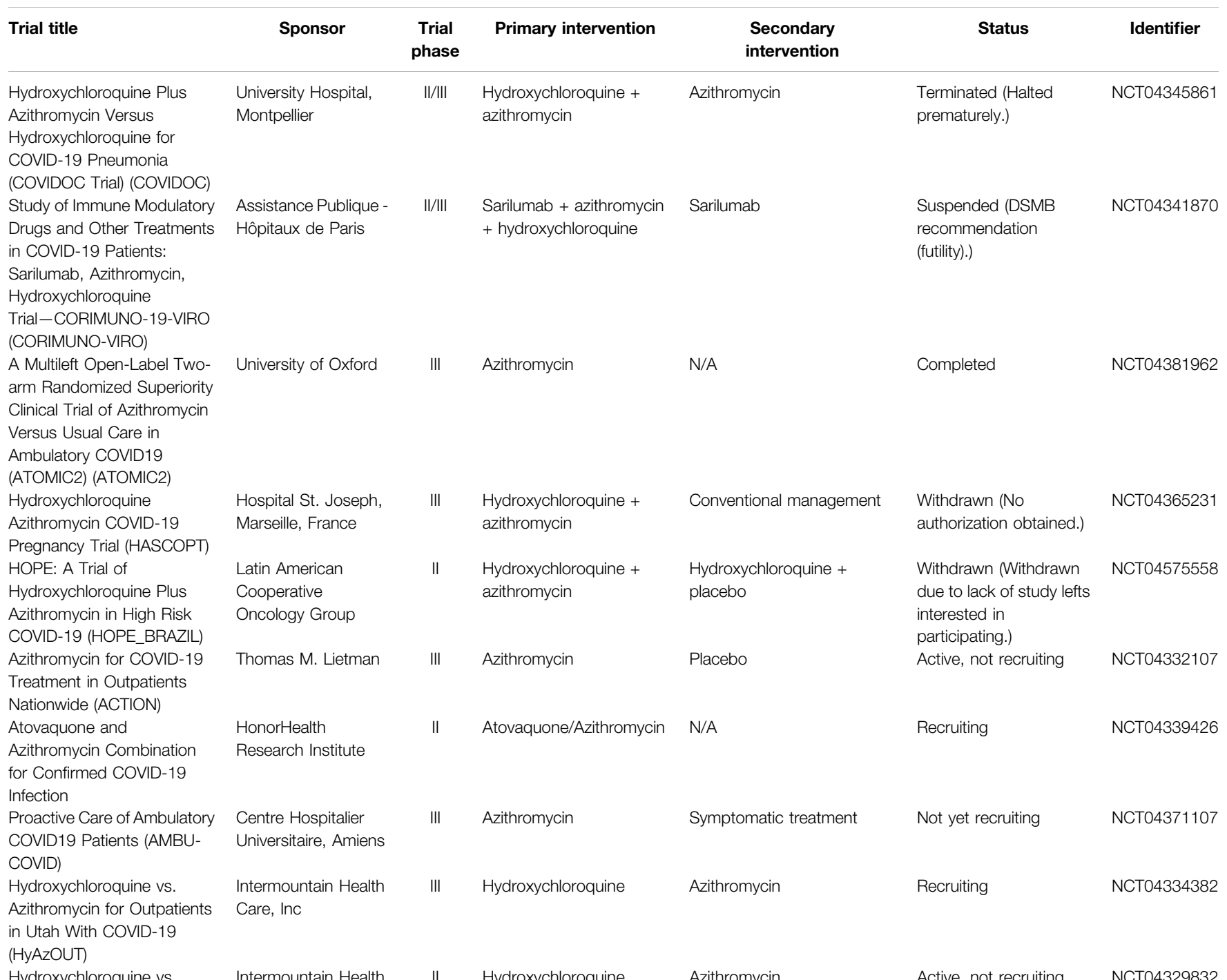

Hydroxychloroquine vs.
Azithromycin for Hospitalized

Patients With Suspected or

Confirmed COVID-19

(HAHPS)

Open Label Non-

Comparative Trial of the

Combination of

Care, Inc

Azithromycin

NCT04329832

Hydroxychloroquine and

Azithromycin in the

Treatment of Hospitalized

Patients

Randomized Comparison of

Combination Azithromycin

and Hydroxychloroquine vs.

Hydroxychloroquine Alone

for the Treatment of

Confirmed COVID-19

Azithromycin + Amoxicillin/

Nantes University

Hospital

Clavulanate in COVID19

Patients with Pneumonia in

Non-intensive Unit (AziA)
University of New

Mexico

Rutgers, The State

University of New

Jersey
III Hydroxychloroquine
Active, not recruiting NCT04322123 (Continued on following page) 
TABLE 6 | (Continued) Summary of clinical trials of azithromycin on COVID-19 treatment.

\begin{tabular}{|c|c|c|c|c|c|c|}
\hline Trial title & Sponsor & $\begin{array}{c}\text { Trial } \\
\text { phase }\end{array}$ & Primary intervention & $\begin{array}{l}\text { Secondary } \\
\text { intervention }\end{array}$ & Status & Identifier \\
\hline $\begin{array}{l}\text { Safety and Efficacy of } \\
\text { Hydroxychloroquine } \\
\text { Associated with Azithromycin } \\
\text { in SARS-Cov-2 Virus } \\
\text { (COVID-19) (Coalition-I) }\end{array}$ & & & & $\begin{array}{l}\text { Hydroxychloroquine + } \\
\text { azithromycin }\end{array}$ & & \\
\hline $\begin{array}{l}\text { Hydroxychloroquine, } \\
\text { Azithromycin in the } \\
\text { Treatment of Covid-19 } \\
\text { (PACTT) }\end{array}$ & $\begin{array}{l}\text { Centre Hôpital } \\
\text { Universitaire Farhat } \\
\text { Hached }\end{array}$ & III & $\begin{array}{l}\text { Hydroxychloroquine + } \\
\text { azithromycin }\end{array}$ & $\begin{array}{l}\text { Hydroxychloroquine + } \\
\text { placebo }\end{array}$ & Not yet recruiting & NCT04405921 \\
\hline $\begin{array}{l}\text { Evaluation of Prognostic } \\
\text { Modification in COVID-19 } \\
\text { Patients in Early Intervention } \\
\text { Treatment }\end{array}$ & Gilberto Cruz arteaga & III & $\begin{array}{l}\text { Azithromycin + ivermectin } \\
+ \text { ribaroxaban + } \\
\text { paracetamol }\end{array}$ & $\begin{array}{l}\text { Azithromycin + ribaroxaban + } \\
\text { paracetamol }\end{array}$ & Recruiting & NCT04673214 \\
\hline $\begin{array}{l}\text { Evaluating the Efficacy of } \\
\text { Hydroxychloroquine and } \\
\text { Azithromycin to Prevent } \\
\text { Hospitalization or Death in } \\
\text { Persons With COVID-19 }\end{array}$ & $\begin{array}{l}\text { National Institute of } \\
\text { Allergy and Infectious } \\
\text { Diseases (NIAID) }\end{array}$ & $\|$ & $\begin{array}{l}\text { Hydroxychloroquine + } \\
\text { azithromycin }\end{array}$ & Placebo & $\begin{array}{l}\text { Terminated (Slow } \\
\text { enrollment and lack of } \\
\text { community enthusiasm.) }\end{array}$ & NCT04358068 \\
\hline $\begin{array}{l}\text { Hydroxychloroquine } \\
\text { Monotherapy and in }\end{array}$ & $\begin{array}{l}\text { Novartis } \\
\text { Pharmaceuticals }\end{array}$ & III & Hydroxychloroquine & $\begin{array}{l}\text { Hydroxychloroquine + } \\
\text { azithromycin }\end{array}$ & Completed & NCT04358081 \\
\hline
\end{tabular}

Combination with

Azithromycin in Patients With

Moderate and Severe

COVID-19 Disease

A Single-blinded,

Randomized, Placebo

Controlled phase II Trial of

Prophylactic Treatment With

Oral Azithromycin Versus

Placebo in Cancer Patients

Undergoing Antineoplastic

Treatment During the Corona

Virus Disease 19 (COVID-19)

Pandemic

Efficacy of

Hydroxychloroquine,

Telmisartan and Azithromycin

on the Survival of

Hospitalized Elderly Patients

With COVID-19 (COVID-

Aging)

Proactive Protection With

Azithromycin and

Hydroxychloroquine in

Hospitalized Patients With

COVID-19 (ProPAC-COVID)

Azithromycin Added to

Hydroxychloroquine in

Patients Admitted to

Intensive Care With COVID-

19: Randomized Controlled

Trial (AZIQUINE-ICU)

Open Label Study to

Compare Efficacy, Safety

and Tolerability of

Hydroxychloroquine

Combined With Azithromycin

Compared to

Hydroxychloroquine

Combined With Camostat

Mesylate and to "No

Treatment" in SARS CoV 2

Virus (COSTA)
University Hospital,

Strasbourg, France

Prof. Dr. Matthias

Preusser

Chronic Obstructive Pulmonary Disease

Trial Network,

Denmark

Frantisek Duska,

$\mathrm{MD}, \mathrm{PhD}$

Sheba Medical

Center
II Azithromycin

III

Hydroxychloroquine

II

Hydroxychloroquine + azithromycin

III Hydroxychloroquine + azithromycin

III Hydroxychloroquine + azithromycin
Hydroxychloroquine + camostat mesylate
Terminated (Steering

Committee decision in accordance with stopping rule 1: Emergence of new data.)

Recruiting
NCT04369365 
TABLE 6 | (Continued) Summary of clinical trials of azithromycin on COVID-19 treatment.

\begin{tabular}{|c|c|c|c|c|c|c|}
\hline Trial title & Sponsor & $\begin{array}{c}\text { Trial } \\
\text { phase }\end{array}$ & Primary intervention & $\begin{array}{l}\text { Secondary } \\
\text { intervention }\end{array}$ & Status & Identifier \\
\hline $\begin{array}{l}\text { Asymptomatic COVID-19 } \\
\text { Trial (ACT) }\end{array}$ & $\begin{array}{l}\text { Rutgers, The State } \\
\text { University of New } \\
\text { Jersey }\end{array}$ & $\|$ & $\begin{array}{l}\text { Hydroxychloroquine + } \\
\text { azithromycin }\end{array}$ & Placebo & $\begin{array}{l}\text { Withdrawn (The } \\
\text { investigators have } \\
\text { decided not to go } \\
\text { forward with this } \\
\text { protocol.) }\end{array}$ & NCT04374552 \\
\hline
\end{tabular}

Hydroxychloroquine and Zinc With Either Azithromycin or Doxycycline for Treatment of COVID-19 in Outpatient

\section{Setting}

Epidemiology of SARS-CoV-

2 and Mortality to Covid19

Disease in French Cancer

Patients (ONCOVID)

Use of Hydroxychloroquine

Alone or Associated for

Inpatients With SARS-CoV2

Virus (COVID-19)

Phytomedicines Versus

Hydroxychloroquine as an

Add On Therapy to

Azithromycin in

Asymptomatic Covid-19

Patients (PHYTCOVID-19)

Study Evaluating the Efficacy

of Hydroxychloroquine and

Azithromycin in Patients With

COVID-19 and

Hematological Malignancies

(HYACINTHE) (HYACINTHE)

Hydroxychloroquine,

Oseltamivir and Azithromycin

for the Treatment of COVID-

19 Infection: An RCT

(PROTECT)

Efficacy of Sofosbuvir Plus

Ledipasvir in Egyptian

Patients With COVID-19

Compared to Standard

Treatment

International ALLIANCE

Study of Therapies to Prevent

Progression of COVID-19

VA Remote and Equitable

Access to COVID-19

Healthcare Delivery (VA-

REACH TRIAL) (VA-REACH)

Evaluate the Efficacy and

Safety of Oral

Hydroxychloroquine,

Indomethacin and Zithromax

in Subjects With Mild

Symptoms of COVID-19

(COVID-19)

Effectiveness of

Hydroxychloroquine in

COVID-19 Patients (COVID)
Ft. Francis Hospital, New York

IV Hydroxychloroquine + azithromycin + zinc sulfate

Hydroxychloroquine + protocol.)

Completed

NCT04370782

Gustave Roussy,

Cancer Campus,

Grand Paris

Apsen

Farmaceutica S.A.

Hydroxychloroquine

sulfate

Hydroxychloroquine sulfate + azithromycin

Institute for Research and Development of Medicinal and Food

Plants of Guinea

Institut de

cancérologie

Strasbourg Europe

Shehnoor Azhar

Almaza Military Fever

Hospital

National Institute of

Integrative Medicine,

Australia

Salomeh Keyhani MD

Perseverance

Research

Center, LLC

Prof. Dr. Umar

Farooq
III Azithromycin

\section{Hydroxychloroquine + \\ Quinine + azithromycin} azithromycin

I Hydroxychloroquine + azithromycin

Placebo

Hydroxychloroquine;

oseltamivir;

hydroxychloroquine +

azithromycin;

hydroxychloroquine +

oseltamivir; oseltamivir +

azithromycin;

hydroxychloroquine +

oseltamivir + azithromycin

Oseltamivir +

hydroxychloroquine and

azithromycin

Hydroxychloroquine +

azithromycin + zinc citrate +

vitamin D3 + vitamin B12

hydroxychloroquine +

azithromycin + zinc citrate

+ vitamin D3 + vitamin B12

III Hydroxychloroquine

Azithromycin

Azithromycin; indomethacin
Withdrawn (Competent authority decision.)

Recruiting

Completed

Recruiting

NCT04344457

NCT04341207

NCT04361461 was canceled before

enrollment due to

Sponsor.)

Enrolling by invitation

NCT04501965

NCT04392128

NCT04338698

Recruiting

NCT04395768

Suspended (Concerns

NCT04363203 related to study drug)

Not yet recruiting

NCT04328272 
TABLE 6 | (Continued) Summary of clinical trials of azithromycin on COVID-19 treatment.

\begin{tabular}{|c|c|c|c|c|c|c|}
\hline Trial title & Sponsor & $\begin{array}{c}\text { Trial } \\
\text { phase }\end{array}$ & Primary intervention & $\begin{array}{l}\text { Secondary } \\
\text { intervention }\end{array}$ & Status & Identifier \\
\hline $\begin{array}{l}\text { Levamisole and Isoprinosine } \\
\text { in the Treatment of COVID19: } \\
\text { A Proposed Therapeutic Trial }\end{array}$ & Cairo University & III & Levamisole + isoprinosine & $\begin{array}{l}\text { Azithromycin + } \\
\text { hydroxychloroquine }\end{array}$ & Not yet recruiting & NCT04383717 \\
\hline $\begin{array}{l}\text { Efficacy and Safety of } \\
\text { Favipiravir in COVID-19 } \\
\text { Patients in Indonesia (FVR) }\end{array}$ & Ina-Respond & III & Favipiravir + azithromycin & Favipiravir & $\begin{array}{l}\text { Suspended (Study } \\
\text { halted prematurely but } \\
\text { potentially will resume, } \\
\text { the protocol will be } \\
\text { amended.) }\end{array}$ & NCT04613271 \\
\hline $\begin{array}{l}\text { Treatment in Patients With } \\
\text { Suspected or Confirmed } \\
\text { COVID-19 With Early } \\
\text { Moderate or Severe } \\
\text { Disease (RCT) }\end{array}$ & LCMC Health & III & Hydroxychloroquine & Azithromycin & Active, not recruiting & NCT04344444 \\
\hline $\begin{array}{l}\text { Safety and Efficacy of } \\
\text { Doxycycline and Rivaroxaban } \\
\text { in COVID-19 (DOXYCOV) }\end{array}$ & $\begin{array}{l}\text { Yaounde Central } \\
\text { Hospital }\end{array}$ & IV & $\begin{array}{l}\text { Doxycycline + } \\
\text { Rivaroxaban }\end{array}$ & $\begin{array}{l}\text { Hydroxychloroquine + } \\
\text { azithromycin }\end{array}$ & Recruiting & NCT04715295 \\
\hline $\begin{array}{l}\text { A Study of Quintuple Therapy } \\
\text { to Treat COVID-19 Infection } \\
\text { (HAZDpaC) }\end{array}$ & ProgenaBiome & $\|$ & $\begin{array}{l}\text { Hydroxychloroquine + } \\
\text { azithromycin + vitamin C + } \\
\text { vitamin D + zinc }\end{array}$ & Vitamin $C+$ vitamin $D+$ zinc & Recruiting & NCT04334512 \\
\hline $\begin{array}{l}\text { Safety and Efficacy of } \\
\text { Hydroxychloroquine for the } \\
\text { Treatment and Prevention of } \\
\text { Coronavirus Disease } 2019 \\
\text { (COVID-19) Caused by } \\
\text { Severe Acute Respiratory } \\
\text { Syndrome Coronavirus } 2 \\
\text { (SARS-CoV-2) }\end{array}$ & $\begin{array}{l}\text { International Brain } \\
\text { Research Foundation }\end{array}$ & 1 & $\begin{array}{l}\text { Hydroxychloroquine + } \\
\text { azithromycin + vitamins } \\
\text { and minerals }\end{array}$ & N/A & Not yet recruiting & NCT04590274 \\
\hline $\begin{array}{l}\text { Effectiveness of Ivermectin as } \\
\text { Add-On Therapy in COVID- } \\
19 \text { Management }\end{array}$ & $\begin{array}{l}\text { University of } \\
\text { Baghdad }\end{array}$ & 1 & $\begin{array}{l}\text { Ivermectin + } \\
\text { hydroxychloroquine + } \\
\text { azithromycin }\end{array}$ & N/A & Completed & NCT04343092 \\
\hline $\begin{array}{l}\text { Ivermectin for Severe COVID- } \\
19 \text { Management }\end{array}$ & $\begin{array}{l}\text { Afyonkarahisar } \\
\text { Health Sciences } \\
\text { University }\end{array}$ & III & Ivermectin & $\begin{array}{l}\text { Hydroxychloroquine, } \\
\text { favipiravir and azithromycin }\end{array}$ & Completed & NCT04646109 \\
\hline $\begin{array}{l}\text { Assessment of Efficacy and } \\
\text { Safety of HCQ and } \\
\text { Antibiotics Administrated to } \\
\text { Patients COVID19(+) (COVID } \\
+ \text { PA) }\end{array}$ & $\begin{array}{l}\text { Abderrahmane Mami } \\
\text { Hospital }\end{array}$ & IV & $\begin{array}{l}\text { Hydroxychloroquine + } \\
\text { azithromycin }\end{array}$ & $\mathrm{N} / \mathrm{A}$ & $\begin{array}{l}\text { Withdrawn (- Interest in } \\
\text { the use of } \mathrm{HCQ} \text { is } \\
\text { controversial.) }\end{array}$ & NCT04351919 \\
\hline $\begin{array}{l}\text { Evaluation of the Efficacy and } \\
\text { Safety of Treatments for } \\
\text { Patients Hospitalized for } \\
\text { COVID-19 Infection Without } \\
\text { Signs of Acute Respiratory } \\
\text { Failure, in Tunisia (THINC) }\end{array}$ & $\begin{array}{l}\text { Abderrahmane Mami } \\
\text { Hospital }\end{array}$ & III & $\begin{array}{l}\text { Hydroxychloroquine + } \\
\text { azithromycin }\end{array}$ & $\begin{array}{l}\text { Hydroxychloroquine + } \\
\text { azithromycin + zinc; } \\
\text { azithromycin + doxycycline }\end{array}$ & $\begin{array}{l}\text { Withdrawn (- Interest in } \\
\text { the use of } \mathrm{HCQ} \text { is } \\
\text { controversial.) }\end{array}$ & NCT04528927 \\
\hline $\begin{array}{l}\text { Administration of Allogenic } \\
\text { UC-MSCs as Adjuvant } \\
\text { Therapy for Critically III } \\
\text { COVID-19 Patients }\end{array}$ & Indonesia University & 1 & Oseltamivir + azithromycin & $\begin{array}{l}\text { Oseltamivir + azithromycin + } \\
\text { umbilical-cord derived } \\
\text { mesenchymal stem cells }\end{array}$ & Recruiting & NCT04457609 \\
\hline $\begin{array}{l}\text { OUTpatient Treatment of } \\
\text { COVID-19 in Patients With } \\
\text { Risk Factor for Poor } \\
\text { Outcome (OUTCOV) }\end{array}$ & $\begin{array}{l}\text { Groupe Hospitalier } \\
\text { Paris Saint Joseph }\end{array}$ & III & Azithromycin & $\begin{array}{l}\text { Hydroxychloroquine; } \\
\text { lopinavir/ritonavir }\end{array}$ & $\begin{array}{l}\text { Withdrawn (The PI } \\
\text { decided.) }\end{array}$ & NCT04365582 \\
\hline $\begin{array}{l}\text { A Study of the Effectiveness } \\
\text { of an Off Label Mefloquine } \\
\text { Use for the Treatment of } \\
\text { Patients With COVID19 }\end{array}$ & $\begin{array}{l}\text { Burnasyan Federal } \\
\text { Medical Biophysical } \\
\text { Center }\end{array}$ & $\|/\| \|$ & Mefloquine & $\begin{array}{l}\text { Hydroxychloroquine; } \\
\text { mefloquine + azithromycin } \pm \\
\text { tocilizumab; } \\
\text { hydroxychloroquine }+ \\
\text { azithromycin } \pm \text { tocilizumab }\end{array}$ & Completed & NCT04347031 \\
\hline $\begin{array}{l}\text { Add on to Azithromycin, } \\
\text { Phytomedicine and/or } \\
\text { Antimalarial Drug vs } \\
\text { Hydroxychloroquine in }\end{array}$ & $\begin{array}{l}\text { Institute for Research } \\
\text { and Development of } \\
\text { Medicinal and Food } \\
\text { Plants of Guinea }\end{array}$ & $\|$ & $\begin{array}{l}\text { Hydroxychloroquine + } \\
\text { azithromycin }\end{array}$ & $\begin{array}{l}\text { Cospherunate + } \\
\text { azithromycin; cospherunate } \\
+ \text { phytomedicine + } \\
\text { azithromycin }\end{array}$ & Enrolling by invitation & NCT04502342 \\
\hline
\end{tabular}


TABLE 6 | (Continued) Summary of clinical trials of azithromycin on COVID-19 treatment.

\begin{tabular}{|c|c|c|c|c|c|c|}
\hline Trial title & Sponsor & $\begin{array}{c}\text { Trial } \\
\text { phase }\end{array}$ & Primary intervention & $\begin{array}{l}\text { Secondary } \\
\text { intervention }\end{array}$ & Status & Identifier \\
\hline $\begin{array}{l}\text { Efficacy and Safety of } \\
\text { Hydroxychloroquine and } \\
\text { Favipiravir in the Treatment of } \\
\text { Mild to Moderate COVID-19 }\end{array}$ & $\begin{array}{l}\text { Ministry of Health, } \\
\text { Turkey }\end{array}$ & III & Favipiravir & $\begin{array}{l}\text { Favipiravir + } \\
\text { hydroxychloroquine; } \\
\text { favipiravir + azithromycin; } \\
\text { hydroxychloroquine + } \\
\text { azithromycin }\end{array}$ & Active, not recruiting & NCT04411433 \\
\hline $\begin{array}{l}\text { Efficacy and Safety } \\
\text { Evaluation of Treatment } \\
\text { Regimens in Adult COVID-19 } \\
\text { Patients in Senegal (SEN- } \\
\text { CoV-Fadj) }\end{array}$ & $\begin{array}{l}\text { Institut Pasteur de } \\
\text { Dakar }\end{array}$ & III & $\begin{array}{l}\text { Hydroxychloroquine + } \\
\text { azithromycin }\end{array}$ & $\begin{array}{l}\text { Hydroxychloroquine + } \\
\text { azithromycin + nafamostat } \\
\text { mesilate }\end{array}$ & Recruiting & NCT04390594 \\
\hline
\end{tabular}

(All information in the table are collected from https://clinicaltrials.gov).

compared with the patients without TCZ therapy. It should be noticed that the study performed by Klopfenstein et al. has some limitations, such as the small sample size and the retrospective nature of their work.

Interestingly, Stone et al. (2020) conducted a randomized, double-blind, placebo-controlled study (ClinicalTrials.gov, NCT04356937) with a larger sample size (243 patients with severe SARS-CoV-2 infection). The results from the study of Stone et al. demonstrated that TCZ is not effective in preventing intubation or death. However, some benefits, such as fewer serious infections in patients receiving TCZ therapy, cannot be ignored. Most recently, Salama et al. (2021) performed a trial enrolled with 389 COVID-19 patients (ClinicalTrials.gov, NCT04372186). The results showed that TCZ cannot improve survival rate; it only reduced the possibility of progression to the composite outcome of mechanical ventilation or death for the patients who were not receiving mechanical ventilation. Currently, TCZ undergoes several phase III clinical trials (Clinicaltrials.gov, NCT04423042, NCT04356937, NCT04403685, etc.) to further understand the TCZ treatment as a supportive care option in alleviating the severe respiratory symptoms correlated with SARS-CoV-2 infection (Alzghari and Acuña, 2020). Overall, TCZ appears to be an effective treatment for COVID-19 patients to calm the inflammatory storm and to reduce mortality. Notably, the efficacy of TCZ is controversial and remains to be further determined.

\section{Mepolizumab}

Mepolizumab (brand name: Nucala) is a human monoclonal antibody medication used for the treatment of severe eosinophilic asthma, eosinophilic granulomatosis, and hypereosinophilic syndrome (HES) (Mukherjee et al., 2014; Ennis et al., 2019). Mepolizumab binds to IL-5 and prevents it from binding to its receptor on the surface of eosinophil white blood cells. Notably, some experts recommended to continue the mepolizumab therapy in COVID-19 patients with severe eosinophilic asthma, but the concern is that eosinopenia, which may serve as a diagnostic indicator for COVID-19 disease, may be a risk factor for worse disease outcomes (Li Q. et al., 2020; Du et al.,
2020; Bousquet et al., 2021). In other words, it is a challenge to manage patients with severe eosinophilic asthma infected by SARS-CoV-2. Aksu et al. (2021) reported that no evidence of loss of asthma control was observed during mepolizumab therapy in a woman patient with asthma infected by SARS-CoV-2. In addition, Azim et al. (2021) observed the outcomes from four patients receiving mepolizumab treatment. The researchers found that all four patients had a further reduction in their eosinophil counts within the reference range at the presentation with SARS-CoV-2 infection, but the underlying mechanism is not fully investigated, and subsequently recovered without any immediate evidence of long-term respiratory outcomes. Of note, one of four patients required hospitalization and ventilatory support. They thereby suggested that the mepolizumab therapy should be continued without any changed outcomes in the COVID-19 course. However, evidence from Eger et al. (2020) involved 634 severe asthma patients diagnosed with COVID-19 showed that patients with severe asthma receiving mepolizumab therapy have a more severe course of COVID-19 and an increasing risk of severity of COVID-19 compared with the general population. Overall, because the relevant data are limited, and the guideline is currently absent, maintaining or postponing mepolizumab treatment until the patient recovers from SARS-CoV-2 infection should be a case-by-case based decision for COVID19 patients with severe asthma.

\section{Sarilumab}

Sarilumab (brand name: Kevzara) is a humanized monoclonal antibody against IL-6 receptor. In 2017, FDA approved sarilumab for rheumatoid arthritis treatment (Khiali et al., 2021). It has reported that severe COVID-19 disease is characterized by elevated serum levels of $\mathrm{C}$ reactive protein (CRP) and cytokines, including, but not limited to, IFN- $\gamma$, IL-8, and IL-6 (Conti et al., 2020; Mo et al., 2020; Qin et al., 2020). Hence, this result provides a clue that anti-IL-6 agents have the possibility against SARS-CoV-2 infection. In a retrospective case report involving 15 COVID-19 patients, early intervention with sarilumab could have clinical improvement with decreased 
TABLE 7 | Summary of clinical trials of tocilizumab (TCZ) on COVID-19 treatment.

\begin{tabular}{|c|c|c|c|c|c|c|}
\hline Trial title & Sponsor & $\begin{array}{c}\text { Trial } \\
\text { phase }\end{array}$ & Primary intervention & $\begin{array}{l}\text { Secondary } \\
\text { intervention }\end{array}$ & Status & Identifier \\
\hline $\begin{array}{l}\text { Tocilizumab in Coronavirus-19 } \\
\text { Positive Patients }\end{array}$ & University of Calgary & III & Tocilizumab & $\mathrm{N} / \mathrm{A}$ & Not yet recruiting & NCT04423042 \\
\hline $\begin{array}{l}\text { Efficacy of Tocilizumab on } \\
\text { Patients With COVID-19 }\end{array}$ & $\begin{array}{l}\text { Massachusetts } \\
\text { General Hospital }\end{array}$ & III & Tocilizumab & Placebo & Completed & NCT04356937 \\
\hline $\begin{array}{l}\text { Tocilizumab in COVID-19 } \\
\text { Lahore General Hospital } \\
\text { (TC19LGH) }\end{array}$ & $\begin{array}{l}\text { Lahore General } \\
\text { Hospital }\end{array}$ & I & Tocilizumab & $\mathrm{N} / \mathrm{A}$ & Recruiting & NCT04560205 \\
\hline $\begin{array}{l}\text { Clinical Trial to Evaluate the } \\
\text { Effectiveness and Safety of } \\
\text { Tocilizumab for Treating } \\
\text { Patients With COVID-19 } \\
\text { Pneumonia }\end{array}$ & $\begin{array}{l}\text { Fundacion SEIMC- } \\
\text { GESIDA }\end{array}$ & $\|$ & Tocilizumab & $\mathrm{N} / \mathrm{A}$ & Completed & NCT04445272 \\
\hline $\begin{array}{l}\text { Tocilizumab - An Option for } \\
\text { Patients With COVID-19 } \\
\text { Associated Cytokine Release } \\
\text { Syndrome; A Single Center } \\
\text { Experience }\end{array}$ & $\begin{array}{l}\text { FMH College of } \\
\text { Medicine and } \\
\text { Dentistry }\end{array}$ & IV & Tocilizumab & Methylprednisolone & Completed & NCT04730323 \\
\hline $\begin{array}{l}\text { Safety and Efficacy of } \\
\text { tocilizumab in Moderate to } \\
\text { Severe COVID-19 With } \\
\text { Inflammatory Markers } \\
\text { (TOCIBRAS) }\end{array}$ & $\begin{array}{l}\text { Beneficência } \\
\text { Portuguesa de São } \\
\text { Paulo }\end{array}$ & III & $\begin{array}{l}\text { Tocilizumab + } \\
\text { supportive care }\end{array}$ & Supportive care & Terminated (Safety) & NCT04403685 \\
\hline $\begin{array}{l}\text { Low-Dose Tocilizumab Versus } \\
\text { Standard of Care in } \\
\text { Hospitalized Patients With } \\
\text { COVID-19 (COVIDOSE-2) }\end{array}$ & University of Chicago & $\|$ & Tocilizumab & Standard of care & Recruiting & NCT04479358 \\
\hline $\begin{array}{l}\text { Tocilizumab for SARS-CoV2 } \\
\text { (COVID-19) Severe } \\
\text { Pneumonitis }\end{array}$ & $\begin{array}{l}\text { Università Politecnica } \\
\text { delle Marche }\end{array}$ & $\|$ & Tocilizumab & $\mathrm{N} / \mathrm{A}$ & Active, not recruiting & NCT04315480 \\
\hline $\begin{array}{l}\text { Efficacy of Tocilizumab in } \\
\text { Modifying the Inflammatory } \\
\text { Parameters of Patients With } \\
\text { COVID-19 (COVITOZ-01) } \\
\text { (COVITOZ-01) }\end{array}$ & $\begin{array}{l}\text { Hospital Universitario } \\
\text { Ramon y Cajal }\end{array}$ & $\|$ & Tocilizumab & Standard care & Recruiting & NCT04435717 \\
\hline $\begin{array}{l}\text { Tocilizumab in the Treatment } \\
\text { of Coronavirus Induced } \\
\text { Disease (COVID-19) } \\
\text { (CORON-ACT) }\end{array}$ & $\begin{array}{l}\text { University Hospital } \\
\text { Inselspital, Berne }\end{array}$ & $\|$ & Tocilizumab & Placebo & $\begin{array}{l}\text { Terminated (1.) Not possible } \\
\text { to recruit the planned number } \\
\text { of patients during the planned } \\
\text { study period; 2.) } \\
\text { "Dexamethasone" was } \\
\text { included in the standard of } \\
\text { care for the study population } \\
\text { during the course of the study } \\
\text { and inclusion criteria could no } \\
\text { longer be met.) }\end{array}$ & NCT04335071 \\
\hline $\begin{array}{l}\text { Tocilizumab for Patients With } \\
\text { Cancer and COVID-19 } \\
\text { Disease }\end{array}$ & $\begin{array}{l}\text { National Cancer } \\
\text { Institute (NCl) }\end{array}$ & $\|$ & Tocilizumab & $\mathrm{N} / \mathrm{A}$ & $\begin{array}{l}\text { Terminated (Other - } \\
\text { Randomized data no longer } \\
\text { support continuation.) }\end{array}$ & NCT04370834 \\
\hline $\begin{array}{l}\text { Evaluating Tocilizumab for } \\
\text { Severe COVID-19 Infection in } \\
\text { Breast Cancer vs. Non-Cancer } \\
\text { Pateints }\end{array}$ & Beni-Suef University & $\|$ & Tocilizumab & $\mathrm{N} / \mathrm{A}$ & Recruiting & NCT04871854 \\
\hline $\begin{array}{l}\text { Tocilizumab in COVID-19 } \\
\text { Pneumonia (TOCIVID-19) } \\
\text { (TOCIVID-19) }\end{array}$ & $\begin{array}{l}\text { National Cancer } \\
\text { Institute, Naples }\end{array}$ & $\|$ & Tocilizumab & N/A & Active, not recruiting & NCT04317092 \\
\hline $\begin{array}{l}\text { Tocilizumab Treatment in } \\
\text { Patients With COVID-19 }\end{array}$ & $\begin{array}{l}\text { Instituto Nacional de } \\
\text { Cancerologia de } \\
\text { Mexico }\end{array}$ & $\|$ & Tocilizumab & $\mathrm{N} / \mathrm{A}$ & Active, not recruiting & NCT04363853 \\
\hline $\begin{array}{l}\text { Trial of Tocilizumab for } \\
\text { Treatment of Severe COVID- } \\
\text { 19: ARCHITECTS } \\
\text { (ARCHITECTS) }\end{array}$ & $\begin{array}{l}\text { Queen's Medical } \\
\text { Centre }\end{array}$ & III & Tocilizumab & Placebo & Recruiting & NCT04412772 \\
\hline $\begin{array}{l}\text { Tocilizumab to Prevent Clinical } \\
\text { Decompensation in }\end{array}$ & University of Chicago & $\|$ & Tocilizumab & $\mathrm{N} / \mathrm{A}$ & Completed & NCT04331795 \\
\hline
\end{tabular}


TABLE 7 | (Continued) Summary of clinical trials of tocilizumab (TCZ) on COVID-19 treatment.

Trial title Sponsor $\quad \begin{gathered}\text { Trial } \\ \text { phase }\end{gathered}$ Primary intervention $\quad \begin{gathered}\text { Secondary } \\ \text { intervention }\end{gathered}$

Hospitalized, Non-Critically III

Patients With COVID-19

Pneumonitis (COVIDOSE)

Assessment of Efficacy and

Safety of Tocilizumab

Compared to DefeROxamine,

Associated With Standards

Treatments in COVID-19 (+)

Patients Hospitalized in

Intensive Care in Tunisia

(TRONCHER)

Comparison of Tocilizumab

Plus Dexamethasone vs.

Dexamethasone for Patients

With Covid-19 (TOCIDEX)

Tocilizumab Versus

Methylprednisolone in the

Cytokine Release Syndrome of

Patients With COVID-19

Clinical Trial of the Use of

tocilizumab for Treatment of

SARS-CoV-2 Infection

(COVID-19) (TOCOVID)

Tocilizumab for Prevention of

Respiratory Failure in Patients

With Severe COVID-19

Infection

Clinical Efficacy of Heparin and

Tocilizumab in Patients With

Severe COVID-19 Infection

(hepmab)

Study to Evaluate the Efficacy and Safety of Tocilizumab

Versus Corticosteroids in

Hospitalized COVID-19

Patients With High Risk of

Progression

Efficacy of Early Administration

of Tocilizumab in COVID-19

Patients

The Use of Tocilizumab in the

Management of Patients Who

Have Severe COVID-19 With

Suspected Pulmonary

Hyperinflammation

A Study in Patients With

COVID-19 and Respiratory

Distress Not Requiring

Mechanical Ventilation, to

Compare Standard-of-Care

With Anakinra and Tocilizumab

Treatment the

Immunomodulation-CoV

Assessment (ImmCoVA) Study

A Study to Evaluate the Safety

and Efficacy of Tocilizumab in

Patients With Severe COVID-

19 Pneumonia (COVACTA)

A Study to Investigate

Intravenous Tocilizumab in

Participants With Moderate to

Severe COVID-19 Pneumonia (MARIPOSA)

$\begin{array}{lllll}\begin{array}{l}\text { Abderrahmane Mami N II } \\ \text { Hospital }\end{array} & \text { Tocilizumab } & \text { Deferoxamine } & \text { Not yet recruiting } & \text { NCT04361032 }\end{array}$

Assistance Publique - $\quad$ II Dexamethasone + Dexamethasone Recruiting

NCT04476979

Hôpitaux de Paris tocilizumab

Hospital Sao

॥ Tocilizumab

Methylprednisolone

Not yet recruiting

NCT04377503

Domingos

Fundació Institut de

II Tocilizumab +

Hydroxychloroquine +

Recruiting

NCT04332094

Recerca de l'Hospital

de la Santa Creu i

Sant Pau

Memorial Sloan

Kettering Cancer

Center

University of Sao

Paulo

hydroxychloroquine + azithromycin

azithromycin

II Tocilizumab

N/A

Active, not recruiting

NCT04377659

University of Malaya

III Tocilizumab

Methylprednisolone

Not yet recruiting

NCT04345445

Azienda Unità

Sanitaria Locale

Reggio Emilia

Hadassah Medical

Organization

Karolinska University

Hospital

Tocilizumab + standard

Anakinra + standard of

Recruiting

NCT04412291

Terminated (Based on interim analysis for futility and given an enrollment rate almost nil.)

Recruiting

NCT04346355

NCT04377750

care

Completed

NCT04320615

Hoffmann-La Roche $\quad \| \quad$ Tocilizumab N/A

Completed

NCT04363736 
TABLE 7 | (Continued) Summary of clinical trials of tocilizumab (TCZ) on COVID-19 treatment.

\begin{tabular}{|c|c|c|c|c|c|c|}
\hline Trial title & Sponsor & $\begin{array}{c}\text { Trial } \\
\text { phase }\end{array}$ & Primary intervention & $\begin{array}{l}\text { Secondary } \\
\text { intervention }\end{array}$ & Status & Identifier \\
\hline $\begin{array}{l}\text { A Study to Evaluate the } \\
\text { Efficacy and Safety of } \\
\text { Tocilizumab in Hospitalized } \\
\text { Participants With COVID-19 } \\
\text { Pneumonia (EMPACTA) }\end{array}$ & Genentech, Inc & III & Tocilizumab & Placebo & Recruiting & NCT04372186 \\
\hline $\begin{array}{l}\text { COVID-19: Salvage } \\
\text { Tocilizumab as a Rescue } \\
\text { Measure (COVIDSTORM) }\end{array}$ & Jarmo Oksi & III & Tocilizumab & Standard of care & Recruiting & NCT04577534 \\
\hline $\begin{array}{l}\text { A Trial Using Anakinra, } \\
\text { Tocilizumab Alone or in } \\
\text { Association With Ruxolitinib in } \\
\text { Severe Stage } 2 b \text { and } 3 \text { of } \\
\text { COVID19-Associated Disease } \\
\text { (INFLAMMACOV) }\end{array}$ & $\begin{array}{l}\text { Assistance Publique } \\
\text { Hopitaux De Marseille }\end{array}$ & III & $\begin{array}{l}\text { Tocilizumab } \pm \\
\text { ruxolitinib }\end{array}$ & Anakinra \pm ruxolitinib & Not yet recruiting & NCT04424056 \\
\hline $\begin{array}{l}\text { Tocilizumab for the Treatment } \\
\text { of Cytokine Release Syndrome } \\
\text { in Patients With COVID-19 } \\
\text { (SARS-CoV-2 Infection) }\end{array}$ & Emory University & III & $\begin{array}{l}\text { Tocilizumab + standard } \\
\text { of care }\end{array}$ & Standard of care & $\begin{array}{l}\text { Withdrawn (Study } \\
\text { abandoned due to drug } \\
\text { billing issues.) }\end{array}$ & NCT04361552 \\
\hline $\begin{array}{l}\text { Checkpoint Blockade in } \\
\text { COVID-19 Pandemic } \\
\text { (COPERNICO) }\end{array}$ & MedSIR & $\|$ & $\begin{array}{l}\text { Tocilizumab + } \\
\text { pembrolizumab }\end{array}$ & Standard of care & Recruiting & NCT04335305 \\
\hline $\begin{array}{l}\text { Personalized Immunotherapy } \\
\text { for SARS-CoV-2 (COVID-19) } \\
\text { Associated With Organ } \\
\text { Dysfunction (ESCAPE) }\end{array}$ & $\begin{array}{l}\text { Hellenic Institute for } \\
\text { the Study of Sepsis }\end{array}$ & $\|$ & Tocilizumab & Anakinra & Completed & NCT04339712 \\
\hline $\begin{array}{l}\text { Treatment of COVID-19 } \\
\text { Patients With Anti-Interleukin } \\
\text { Drugs (COV-AID) }\end{array}$ & $\begin{array}{l}\text { University Hospital, } \\
\text { Ghent }\end{array}$ & III & Tocilizumab & $\begin{array}{l}\text { Anakinra + tocilizumab; } \\
\text { anakinra; anakinra + } \\
\text { siltuximab; usual care }\end{array}$ & Active, not recruiting & NCT04330638 \\
\hline
\end{tabular}

(All information in the table are collected from https://clinicaltrials.gov).

CRP level to patients with COVID-19 disease. More importantly, serum levels of CRP could be a potential biomarker for treatment response (Montesarchio et al., 2020). An open-label cohort study assessed the clinical outcome of sarilumab among 28 patients infected by SARS-CoV-2 compared with 28 contemporary patients receiving standard of care alone (Della-Torre et al., 2020). The results indicated that no significant difference was observed between sarilumab and standard of care. Of note, the clinical improvement suggested that sarilumab is relative to faster recovery in a subset of patients showing minor lung consolidation at baseline. In addition, there are several ongoing clinical trials to evaluate the effectiveness of sarilumab either plus standard of care (Caballero Bermejo et al., 2020) or combined with corticosteroids (ClinicalTrials.gov, NCT04357808) (Garcia-Vicuña et al., 2020) on COVID-19 disease. To date, the overall evaluation toward sarilumab on COVID-19 disease is much positive, which needs further tracking in the future.

\section{Stem cell-based therapy}

To date, most studies regarding stem-based therapy to SARSCoV-2 infection have focused on mesenchymal stem cells (MSCs) (Choudhery and Harris, 2020). MSC-based therapy has the ability to suppress the cytokine storm by secreting anti-inflammatory, anti-apoptosis, and antifibrosis cytokines. Also, MSCs contribute to antibacterial activity, as well as tissue repair and regeneration
(Sadeghi et al., 2020). Table 8 shows clinical trials of MSCs on COVID-19 treatment. For patients suffering from COVID-19, MSCs would repair damaged alveolar epithelial cells and blood vessels, and also prevent pulmonary fibrosis (Chen et al., 2018; Leeman et al., 2019; Zanoni et al., 2019; Afra and Matin, 2020; Li Z. et al., 2020; Golchin et al., 2020). Seven COVID-19 patients who received intravenous transplantation of MSCs had significantly improved pulmonary function in 2 days after transplantation (Leng et al., 2020). Notably, the increased peripheral lymphocytes and IL-10 level, decreased C-reactive protein (CRP) and TNF-a level, and disappeared overactivated cytokine-secreting immune cells were observed within 14 days after MSC injection. Interestingly, Jayaramayya et al. reported that MSC-derived exosomes (MSC-Exo) may be an option to improve the clinical response to COVID-19 patients (Jayaramayya et al., 2020). A phase I clinical trial investigated the use of MSC-Exo inhalation to alleviate COVID-19-induced symptoms (clinicaltrials.gov, NCT04276987). Moreover, MSClike derivatives have acceptable safety and efficacy for COVID-19 treatment in preclinical and clinical studies (Li Z. et al., 2020).

However, some limitations remain to be considered (Sadeghi et al., 2020). First, some patients with, including, but not limited to, a history of malignant tumor, coinfections of other respiratory viruses, and pregnant woman are not eligible to evolve in clinical trials. Most clinical trials worldwide remain in phase I and II, and 
TABLE 8 | Summary of clinical trials of mesenchymal stem cells (MSCs) on COVID-19 treatment.

\begin{tabular}{|c|c|c|c|c|c|c|}
\hline Trial title & Sponsor & $\begin{array}{c}\text { Trial } \\
\text { phase }\end{array}$ & Primary intervention & $\begin{array}{l}\text { Secondary } \\
\text { intervention }\end{array}$ & Status & Identifier \\
\hline $\begin{array}{l}\text { Mesenchymal Stem Cell } \\
\text { Infusion for COVID-19 Infection }\end{array}$ & Dr. Zaineb Akram & $\|$ & Mesenchymal stem cells & Placebo & Recruiting & NCT04444271 \\
\hline $\begin{array}{l}\text { Treatment of COVID-19 } \\
\text { Associated Pneumonia With } \\
\text { Allogenic Pooled Olfactory } \\
\text { Mucosa-Derived Mesenchymal } \\
\text { Stem Cells }\end{array}$ & $\begin{array}{l}\text { Institute of Biophysics } \\
\text { and Cell Engineering of } \\
\text { National Academy of } \\
\text { Sciences of Belarus }\end{array}$ & $|/| \mid$ & $\begin{array}{l}\text { Allogenic pooled olfactory } \\
\text { mucosa-derived mesenchymal } \\
\text { stem cells }\end{array}$ & Standard treatment & $\begin{array}{l}\text { Enrolling by } \\
\text { invitation }\end{array}$ & NCT04382547 \\
\hline $\begin{array}{l}\text { Safety and Efficacy of } \\
\text { Intravenous Wharton's Jelly } \\
\text { Derived Mesenchymal Stem } \\
\text { Cells in Acute Respiratory } \\
\text { Distress Syndrome Due to } \\
\text { COVID } 19\end{array}$ & BioXcellerator & $\mid / I I$ & $\begin{array}{l}\text { Wharton's Jelly derived } \\
\text { mesenchymal stem cells }\end{array}$ & $\begin{array}{l}\text { Hydroxychloroquine, } \\
\text { lopinavir/ritonavir or } \\
\text { azithromycin and placebo }\end{array}$ & Recruiting & NCT04390152 \\
\hline $\begin{array}{l}\text { Cord Blood-Derived } \\
\text { Mesenchymal Stem Cells for } \\
\text { the Treatment of COVID-19 } \\
\text { Related Acute Respiratory } \\
\text { Distress Syndrome }\end{array}$ & $\begin{array}{l}\text { M.D. Anderson Cancer } \\
\text { Center }\end{array}$ & $\mid / I I$ & Mesenchymal stem cells & Standard of care & Recruiting & NCT04565665 \\
\hline $\begin{array}{l}\text { Mesenchymal Stem Cell for } \\
\text { Acute Respiratory Distress } \\
\text { Syndrome Due for COVID-19 } \\
\text { (COVID-19) }\end{array}$ & $\begin{array}{l}\text { Instituto Nacional de } \\
\text { Ciencias Medicas y } \\
\text { Nutricion Salvador } \\
\text { Zubiran }\end{array}$ & $\|$ & Mesenchymal stem cells & $\mathrm{N} / \mathrm{A}$ & Recruiting & NCT04416139 \\
\hline $\begin{array}{l}\text { Bone Marrow-Derived } \\
\text { Mesenchymal Stem Cell } \\
\text { Treatment for Severe Patients } \\
\text { With Coronavirus Disease } 2019 \\
\text { (COVID-19) }\end{array}$ & $\begin{array}{l}\text { Guangzhou Institute of } \\
\text { Respiratory Disease }\end{array}$ & $\|$ & $\begin{array}{l}\text { Bone marrow-derived } \\
\text { mesenchymal stem cells }\end{array}$ & Placebo & $\begin{array}{l}\text { Not yet } \\
\text { recruiting }\end{array}$ & NCT04346368 \\
\hline $\begin{array}{l}\text { Safety and Efficacy of } \\
\text { Mesenchymal Stem Cells in the } \\
\text { Management of Severe COVID- } \\
19 \text { Pneumonia (CELMA) }\end{array}$ & Trustem & $\|$ & $\begin{array}{l}\text { Umbilical cord derived } \\
\text { mesenchymal stem cells }\end{array}$ & Placebo & $\begin{array}{l}\text { Not yet } \\
\text { recruiting }\end{array}$ & NCT04429763 \\
\hline $\begin{array}{l}\text { NestaCell }{ }^{\circledast} \text { Mesenchymal Stem } \\
\text { Cell to Treat Patients With } \\
\text { Severe COVID-19 Pneumonia } \\
\text { (HOPE) }\end{array}$ & Azidus Brasil & $\|$ & $\begin{array}{l}\text { NestaCell }{ }^{\circledast} \text { mesenchymal stem } \\
\text { cells }\end{array}$ & Placebo & $\begin{array}{l}\text { Not yet } \\
\text { recruiting }\end{array}$ & NCT04315987 \\
\hline $\begin{array}{l}\text { Safety and Efficacy Study of } \\
\text { Allogeneic Human Dental Pulp } \\
\text { Mesenchymal Stem Cells to } \\
\text { Treat Severe COVID-19 } \\
\text { Patients }\end{array}$ & $\begin{array}{l}\text { Renmin Hospital of } \\
\text { Wuhan University }\end{array}$ & $\mid / I I$ & $\begin{array}{l}\text { Allogeneic human dental pulp } \\
\text { stem cells }\end{array}$ & Placebo & Recruiting & NCT04336254 \\
\hline $\begin{array}{l}\text { Clinical Trial of Allogeneic } \\
\text { Mesenchymal Cells From } \\
\text { Umbilical Cord Tissue in } \\
\text { Patients With COVID-19 } \\
\text { (MESCEL-COVID19) }\end{array}$ & $\begin{array}{l}\text { Hospital Infantil } \\
\text { Universitario Niño } \\
\text { Jesús, Madrid, Spain }\end{array}$ & $\|$ & $\begin{array}{l}\text { Undifferentiated allogeneic } \\
\text { mesenchymal cells derived } \\
\text { from umbilical cord tissue }\end{array}$ & Standard of care & Recruiting & NCT04366271 \\
\hline $\begin{array}{l}\text { Regenerative Medicine for } \\
\text { COVID-19 and Flu-Elicited } \\
\text { ARDS Using Longeveron } \\
\text { Mesenchymal Stem Cells } \\
\text { (LMSCs) (RECOVER) } \\
\text { (RECOVER) }\end{array}$ & Longeveron LLC & I & $\begin{array}{l}\text { Longeveron mesenchymal } \\
\text { stem cells }\end{array}$ & Placebo & Recruiting & NCT04629105 \\
\hline $\begin{array}{l}\text { Efficacy of Infusions of MSC } \\
\text { From Wharton Jelly in the } \\
\text { SARS-Cov-2 (COVID-19) } \\
\text { Related Acute Respiratory } \\
\text { Distress Syndrome (MSC- } \\
\text { COVID19) }\end{array}$ & $\begin{array}{l}\text { Central Hospital, Nancy, } \\
\text { France }\end{array}$ & $\|$ & $\begin{array}{l}\text { Ex vivo expanded Wharton's } \\
\text { Jelly mesenchymal stem cells }\end{array}$ & Placebo & $\begin{array}{l}\text { Not yet } \\
\text { recruiting }\end{array}$ & NCT04625738 \\
\hline $\begin{array}{l}\text { Study to Evaluate the Efficacy } \\
\text { and Safety of AstroStem-V in } \\
\text { Treatment of COVID-19 } \\
\text { Pneumonia }\end{array}$ & Nature Cell Co. Ltd & $\|$ & $\begin{array}{l}\text { Allogenic adipose tissue- } \\
\text { derived mesenchymal stem } \\
\text { cells }\end{array}$ & N/A & $\begin{array}{l}\text { Not yet } \\
\text { recruiting }\end{array}$ & NCT04527224 \\
\hline $\begin{array}{l}\text { Treatment With Human } \\
\text { Umbilical Cord-Derived }\end{array}$ & Beijing 302 Hospital & $\|$ & $\begin{array}{l}\text { Human umbilical cord- } \\
\text { mesenchymal stem cells }\end{array}$ & Placebo & $\begin{array}{l}\text { Completed } \\
\text { (Continued }\end{array}$ & $\begin{array}{l}\text { NCT04288102 } \\
\text { ollowing page) }\end{array}$ \\
\hline
\end{tabular}


TABLE 8 | (Continued) Summary of clinical trials of mesenchymal stem cells (MSCs) on COVID-19 treatment.

\begin{tabular}{|c|c|c|c|c|c|c|}
\hline Trial title & Sponsor & $\begin{array}{c}\text { Trial } \\
\text { phase }\end{array}$ & Primary intervention & $\begin{array}{l}\text { Secondary } \\
\text { intervention }\end{array}$ & Status & Identifier \\
\hline
\end{tabular}

Mesenchymal Stem Cells for

Severe Corona Virus Disease

2019 (COVID-19)

Treatment of Severe COVID-19

Patients Using Secretome of

Hypoxia-Mesenchymal Stem

Cells in Indonesia

Mesenchymal Stem Cells in

Patients Diagnosed With

COVID-19

Use of UC-MSCs for COVID-19 Camillo Ricordi

Patients

Treatment of COVID-19

Patients Using Wharton's Jelly-

Mesenchymal Stem Cells

Mesenchymal Stem Cell

Treatment for Pneumonia

Patients Infected With

COVID-19

A Clinical Trial to Determine the Hope Biosciences

Safety and Efficacy of Hope

Biosciences Autologous

Mesenchymal Stem Cell

Therapy (HB-adMSCs) to

Provide Protection Against

COVID-19

Umbilical Cord Tissue (UC)

Derived Mesenchymal Stem

Cells (MSCs) Versus Placebo to

Treat Acute Pulmonary

Inflammation Due to COVID-19

(COVID-19)

Clinical Research of Human

Mesenchymal Stem Cells in the

Treatment of COVID-19

Pneumonia

Study of Intravenous

Administration of Allogeneic

Adipose-Derived Mesenchymal

Stem Cells for COVID-19-

Induced Acute Respiratory

Distress

Adipose Mesenchymal Cells for Abatement of SARS-CoV-2

Respiratory Compromise in

COVID-19 Disease

A Randomized, Double-Blind, Hope Biosciences

Placebo-Controlled Clinical

Trial to Determine the Safety

and Efficacy of Hope

Biosciences Allogeneic

Mesenchymal Stem Cell

Therapy (HB-adMSCs) to

Provide Protection Against

COVID-19

Mesenchymal Stem Cells for

the Treatment of COVID-19

Autologous Adipose-derived

Stem Cells (AdMSCs) for

COVID-19

Regeneris Medical
Stem Cell and Cancer

Research Indonesia

Hospital Reg. Lic.

Adolfo Lopez Mateos

Stem Cells Arabia

Beijing 302 Hospital

Joshua M Hare

Puren Hospital Affiliated

to Wuhan University of

Science and

Technology

Sorrento

Therapeutics, Inc

Thomas Advanced

Medical LLC

Celltex Therapeutics

Corporation

Instituto de

Investigación Sanitaria
II

Secretome-mesenchymal stem Standard treatment

Recruiting

NCT04753476 cells + standard care

I Mesenchymal stem cells

$\mathrm{N} / \mathrm{A}$

Recruiting

NCT04611256

I/II Umbilical cord mesenchymal

Vehicle + heparin along with Completed best supportive care

stem cells + heparin alor
best supportive care

I Wharton's Jelly derived

mesenchymal stem cells

N/A

Recruiting

NCT04313322

I Mesenchymal stem cells +

Conventional treatment

Recruiting

NCT04252118 conventional treatment

I $\quad$ Autologous adipose-derived

N/A mesenchymal stem cells$$
\text { A }
$$

I/

Not yet

NCT04490486

mesenchymal stem cells
meal cord tissue-de

II Autologous adipose-derived
Placebo

Placebo

Placebo
Active, not recruiting
NCT04349631
Umbilical cord tissue-derived mesenchymal stem cells

Allogeneic adipose-derived

Not yet recruiting

mesenchymal stem cells

I Autologous adipose-derived mesenchymal stem cells

Allogeneic adipose-derived mesenchymal stem cells

PrimePro $^{\mathrm{TM}}$ mesenchymal stem cells stem cells

Recruiting

NCT04339660

NCT04728698

R

Not yet NCT04352803 recruiting

Active, not

NCT04348435 recruiting

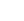

$\begin{array}{lll}\text { Placebo } & \begin{array}{l}\text { Completed } \\ \text { Placebo }\end{array} & \begin{array}{l}\text { Not yet } \\ \text { recruiting }\end{array} \\ & \text { NCT04428801 } \\ \text { Regular treatment } & \begin{array}{l}\text { Suspended } \\ \text { (Lack of } \\ \text { (Continued on following page) }\end{array}\end{array}$


TABLE 8 | (Continued) Summary of clinical trials of mesenchymal stem cells (MSCs) on COVID-19 treatment.

\begin{tabular}{|c|c|c|c|c|c|c|}
\hline Trial title & Sponsor & $\begin{array}{c}\text { Trial } \\
\text { phase }\end{array}$ & Primary intervention & $\begin{array}{l}\text { Secondary } \\
\text { intervention }\end{array}$ & Status & Identifier \\
\hline $\begin{array}{l}\text { BAttLe Against COVID-19 } \\
\text { Using MesenchYmal Stromal } \\
\text { Cells }\end{array}$ & $\begin{array}{l}\text { de la Fundación } \\
\text { Jiménez Díaz }\end{array}$ & & $\begin{array}{l}\text { Allogeneic and expanded } \\
\text { adipose tissue-derived } \\
\text { mesenchymal stromal cells }\end{array}$ & & $\begin{array}{l}\text { financial } \\
\text { support.) }\end{array}$ & \\
\hline $\begin{array}{l}\text { Treatment of Coronavirus } \\
\text { COVID-19 Pneumonia } \\
\text { (Pathogen SARS-CoV-2) With } \\
\text { Cryopreserved Allogeneic } \\
\text { P_MMSCs and UC-MMSCs }\end{array}$ & Institute of Cell Therapy & $\mid / I I$ & $\begin{array}{l}\text { Placenta-derived multipotent } \\
\text { mesenchymal stromal cells + } \\
\text { antibacterial (ceftriaxone, } \\
\text { azithromycin), anticoagulants, } \\
\text { hormones, oxygen therapy }\end{array}$ & $\begin{array}{l}\text { Antibacterial (ceftriaxone, } \\
\text { azithromycin), } \\
\text { anticoagulants, hormones, } \\
\text { oxygen therapy }\end{array}$ & Recruiting & NCT04461925 \\
\hline $\begin{array}{l}\text { A Study of ADR-001 in Patients } \\
\text { With Severe Pneumonia } \\
\text { Caused by SARS-CoV-2 } \\
\text { Infection (COVID-19) }\end{array}$ & $\begin{array}{l}\text { Rohto Pharmaceutical } \\
\text { Co., Ltd }\end{array}$ & $\|$ & Mesenchymal stem cells & Placebo & $\begin{array}{l}\text { Not yet } \\
\text { recruiting }\end{array}$ & NCT04888949 \\
\hline $\begin{array}{l}\text { Umbilical Cord Lining Stem } \\
\text { Cells (ULSC) in Patients With } \\
\text { COVID-19 ARDS (ULSC) }\end{array}$ & Restem, LLC. & $|/| \mid$ & Umbilical cord lining stem cells & Placebo & Recruiting & NCT04494386 \\
\hline $\begin{array}{l}\text { Therapeutic Study to Evaluate } \\
\text { the Safety and Efficacy of DW- } \\
\text { MSC in COVID-19 Patients } \\
\text { (DW-MSC) }\end{array}$ & Ina-Respond & 1 & $\begin{array}{l}\text { Allogeneic mesenchymal stem } \\
\text { cells }\end{array}$ & Placebo & Completed & NCT04535856 \\
\hline $\begin{array}{l}\text { Use of hUC-MSC Product (BX- } \\
\text { U001) for the Treatment of } \\
\text { COVID-19 With ARDS }\end{array}$ & Baylx Inc & $|/| \mid$ & $\begin{array}{l}\text { Human umbilical cord } \\
\text { mesenchymal stem cells }+ \\
\text { supportive care }\end{array}$ & $\begin{array}{l}\text { Placebo control + } \\
\text { supportive care }\end{array}$ & $\begin{array}{l}\text { Not yet } \\
\text { recruiting }\end{array}$ & NCT04452097 \\
\hline $\begin{array}{l}\text { Efficacy and Safety Study of } \\
\text { Allogeneic HB-adMSCs for the } \\
\text { Treatment of COVID-19 }\end{array}$ & Hope Biosciences & $\|$ & $\begin{array}{l}\text { Allogeneic adipose-derived } \\
\text { mesenchymal stem cells }\end{array}$ & Placebo & $\begin{array}{l}\text { Active, not } \\
\text { recruiting }\end{array}$ & NCT04362189 \\
\hline $\begin{array}{l}\text { Clinical Use of Stem Cells for } \\
\text { the Treatment of COVID-19 }\end{array}$ & $\begin{array}{l}\text { SBÜ Dr. Sadi Konuk } \\
\text { Eğitim ve Araştırma } \\
\text { Hastanesi }\end{array}$ & 1 & Mesenchymal stem cells & Placebo & Recruiting & NCT04392778 \\
\hline $\begin{array}{l}\text { Mesenchymal Stromal Cells for } \\
\text { the Treatment of SARS-CoV-2 } \\
\text { Induced Acute Respiratory } \\
\text { Failure (COVID-19 Disease) }\end{array}$ & $\begin{array}{l}\text { Baylor College of } \\
\text { Medicine }\end{array}$ & $|/| \mid$ & Mesenchymal stem cells & Supportive care & Recruiting & NCT04345601 \\
\hline $\begin{array}{l}\text { Efficacy and Safety Evaluation } \\
\text { of Mesenchymal Stem Cells for } \\
\text { the Treatment of Patients with } \\
\text { Respiratory Distress Due to } \\
\text { COVID-19 (COVIDMES) }\end{array}$ & Banc de Sang i Teixits & $|/| \mid$ & $\begin{array}{l}\text { Wharton's Jelly derived } \\
\text { mesenchymal stem cells }\end{array}$ & Placebo & Recruiting & NCT04390139 \\
\hline $\begin{array}{l}\text { Mesenchymal Stem Cells } \\
\text { (MSCs) in Inflammation- }\end{array}$ & $\begin{array}{l}\text { University Hospital } \\
\text { Tuebingen }\end{array}$ & $\|$ & Mesenchymal stem cells & N/A & $\begin{array}{l}\text { Not yet } \\
\text { recruiting }\end{array}$ & NCT04377334 \\
\hline
\end{tabular}

Resolution Programs of

Coronavirus Disease 2019

(COVID-19) Induced Acute

Respiratory Distress Syndrome (ARDS)

Study of the Safety of

Therapeutic Tx With

Immunomodulatory MSC in

Adults With COVID-19 Infection

Requiring Mechanical

Ventilation

The Use of Exosomes for the

Treatment of Acute Respiratory

Distress Syndrome or Novel

Coronavirus Pneumonia

Caused by COVID-19

(ARDOXSO)

A phase II Study in Patients Stemedica Cell

With Moderate to Severe ARDS Technologies, Inc

Due to COVID-19

Repair of Acute Respiratory Belfast Health and

Distress Syndrome by Stromal Social Care Trust

Cell Administration (REALIST)

(COVID-19) (REALIST)

\author{
ImmunityBio, Inc \\ AVEM HealthCare
}

I/II Mesenchymal stem

II Allogeneic mesenchymal stem

I/II Human umbilical cord-derived CD362-enriched mesenchymal stem cells cell-exosomes cells

Immunomodulatory

mesenchymal stem cells

Placebo

N/A

Placebo

Placebo
Recruiting

NCT04397796

Recruiting

Not yet recruiting

NCT04798716

Recruiting

NCT04780685

NCT03042143 
TABLE 8 | (Continued) Summary of clinical trials of mesenchymal stem cells (MSCs) on COVID-19 treatment.

\begin{tabular}{|c|c|c|c|c|c|c|}
\hline Trial title & Sponsor & $\begin{array}{c}\text { Trial } \\
\text { phase }\end{array}$ & Primary intervention & $\begin{array}{l}\text { Secondary } \\
\text { intervention }\end{array}$ & Status & Identifier \\
\hline $\begin{array}{l}\text { Safety and Feasibility of } \\
\text { Allogenic MSC in the Treatment } \\
\text { of COVID-19 (COVID19) }\end{array}$ & $\begin{array}{l}\text { Hospital de Clinicas de } \\
\text { Porto Alegre }\end{array}$ & 1 & Mesenchymal stem cells & $\mathrm{N} / \mathrm{A}$ & $\begin{array}{l}\text { Not yet } \\
\text { recruiting }\end{array}$ & NCT04467047 \\
\hline $\begin{array}{l}\text { Efficacy of Intravenous } \\
\text { Infusions of Stem Cells in the } \\
\text { Treatment of COVID-19 } \\
\text { Patients }\end{array}$ & Jinnah Hospital & $\|$ & $\begin{array}{l}\text { Umbilical cord-derived } \\
\text { mesenchymal stem cells }+ \\
\text { standard care }\end{array}$ & Standard care & Recruiting & NCT04437823 \\
\hline $\begin{array}{l}\text { Treatment of Severe COVID-19 } \\
\text { Pneumonia With Allogeneic } \\
\text { Mesenchymal Stromal Cells } \\
\text { (COVID_MSV) (COVID_MSV) }\end{array}$ & Red de Terapia Celular & $\|$ & Mesenchymal stromal cells & Placebo & Recruiting & NCT04361942 \\
\hline $\begin{array}{l}\text { Multiple Dosing of } \\
\text { Mesenchymal Stromal Cells in } \\
\text { Patients With ARDS } \\
\text { (COVID-19) }\end{array}$ & $\begin{array}{l}\text { Masonic Cancer Center, } \\
\text { University of Minnesota }\end{array}$ & $\|$ & Mesenchymal stromal cells & Placebo & $\begin{array}{l}\text { Active, not } \\
\text { recruiting }\end{array}$ & NCT04466098 \\
\hline $\begin{array}{l}\text { Cellular Immuno-Therapy for } \\
\text { COVID-19 Acute Respiratory } \\
\text { Distress Syndrome (CIRCA-19) }\end{array}$ & $\begin{array}{l}\text { Ottawa Hospital } \\
\text { Research Institute }\end{array}$ & $|/| \mid$ & Mesenchymal Stromal Cells & $\mathrm{N} / \mathrm{A}$ & Completed & NCT04400032 \\
\hline
\end{tabular}

(All information in the table are collected from https://clinicaltrials.gov).

comprehensive results are not clear. Furthermore, it is difficult to evaluate the effectiveness of MSC therapy alone when coadministration with other conventional drugs, such as remdesivir or dexamethasone, in many cases. Importantly, the standard therapeutic protocol, such as administration route, dosage, and transplantation frequency, needs to be determined. Nevertheless, the MSC profile on the immune system provides researchers evidence that it may be a good candidate as a combination therapy of infectious diseases such as COVID-19. Overall, MSC-based therapy appears to be a potential and promising therapeutic method to overcome SARS-CoV-2 infection.

\section{Convalescence plasma transfusion}

Convalescent plasma treatment provides immediate immunity by passive polyclonal antibody administration (Mair-Jenkins et al., 2015). The efficacy of convalescent plasma transfusion may result from viremia suppression (Chen L. et al., 2020). It has reported that convalescent plasma treatment can be used to improve the survival rate on patients with severe acute respiratory syndromes of viral etiology (Mair-Jenkins et al., 2015). Several studies indicated that SARS patients who were treated with convalescent plasma had a shorter hospital stay and lower mortality than those who were not treated with convalescent plasma (Soo et al., 2004; Cheng et al., 2005; Lai, 2005). Table 9 shows the clinical trials of convalescent plasma transfusion on COVID-19 treatment. Based on the findings from recent studies, initiating treatment no later than 5 days may be the most appropriate (Woelfel et al., 2020; Zhao et al., 2020b). Tiberghien et al. (2020) recommend that convalescent plasma administration at the early phases of the disease in patients at high risk of deleterious evolution may reduce the frequency of patient deterioration and, thereby, COVID-19 mortality. Also, close monitoring is necessary to detect any unintended side effects. However, a randomized trial (clinicaltrials.gov, NCT04383535) evolved in 228 COVID-19 patients to evaluate the clinical status after convalescent plasma intervention was added to standard treatment (Simonovich et al., 2021). Unfortunately, no significant differences were found in clinical outcomes or overall mortality between patients infused with convalescent plasma added to standard treatment and those who received standard treatment alone within 30 days. Similarly, an open-label, multicenter, randomized clinical trial (www.chictr.org.cn, ChiCTR2000029757) was performed in seven medical centers with 103 COVID-19 patients (Li L. et al., 2020). The results showed that convalescent plasma therapy in addition to standard treatment, compared with standard treatment alone, did not result in a significant improvement in time to clinical improvement within 28 days. Of note, it is known that other treatments, including antiviral drugs, steroids, and intravenous immunoglobulin, have the possibility to affect the relationship between convalescent plasma and antibody level (Luke et al., 2006). Thus, it is controversial whether it is worthwhile to examine the safety and efficacy of convalescent plasma intervention against SARS-CoV-2 infection in further randomized clinical trials.

\section{Vaccines}

An efficacious vaccine is critical to prevent morbidity and mortality caused by COVID-19. There are four categories of COVID-19 vaccines under clinical evaluation, including wholepathogen vaccines (inactivated vaccines), subunit vaccines, and nucleic acid (DNA and mRNA) vaccines. However, defining and assessing an efficacious vaccine is complex. In the case of SARSCoV-2 infection, an efficacious vaccine could reduce the likelihood of an infection in an individual, severity of a disease 
TABLE 9 | Summary of clinical trials of convalescence plasma on COVID-19 treatment.

\begin{tabular}{|c|c|c|c|c|c|c|}
\hline Trial title & Sponsor & $\begin{array}{c}\text { Trial } \\
\text { phase }\end{array}$ & Primary intervention & $\begin{array}{c}\text { Secondary } \\
\text { intervention }\end{array}$ & Status & Identifier \\
\hline $\begin{array}{l}\text { Safety in Convalescent } \\
\text { Plasma Transfusion to } \\
\text { COVID-19 }\end{array}$ & $\begin{array}{l}\text { Hospital San Jose } \\
\text { Tec de Monterrey }\end{array}$ & I & Convalescent plasma & $\mathrm{N} / \mathrm{A}$ & $\begin{array}{l}\text { Terminated (Other } \\
\text { clinical trials probed that } \\
\text { the use of convalescent } \\
\text { plasma for patients with } \\
\text { COVID-19 is safe.) }\end{array}$ & NCT04333355 \\
\hline $\begin{array}{l}\text { Convalescent Plasma (PC) } \\
\text { and Human Intravenous } \\
\text { Anti-COVID-19 } \\
\text { Immunoglobulin (IV Anti } \\
\text { COVID-19 IgG) in Patients } \\
\text { Hospitalized for COVID-19 }\end{array}$ & $\begin{array}{l}\text { Lifefactors Zona } \\
\text { Franca, SAS }\end{array}$ & $\|/\| \|$ & Convalescent plasma & $\begin{array}{l}\text { Anti-COVID-19 human } \\
\text { immunoglobulin; standard } \\
\text { therapy (remdesivir, } \\
\text { chloroquine, } \\
\text { hydroxychloroquine, } \\
\text { azithromycin) }\end{array}$ & Not yet recruiting & NCT04395170 \\
\hline $\begin{array}{l}\text { Convalescent Plasma of } \\
\text { COVID-19 to Treat SARS- } \\
\text { COV-2 a Randomized } \\
\text { Doble Blind } 2 \text { Center Trial } \\
\text { (CPC-SARS) }\end{array}$ & $\begin{array}{l}\text { Grupo Mexicano } \\
\text { para el Estudio de la } \\
\text { Medicina Intensiva }\end{array}$ & $\|$ & $\begin{array}{l}\text { Convalescent plasma + } \\
\text { conventional therapy } \\
\text { (azithromycin and } \\
\text { hydroxychloroquine) }\end{array}$ & $\begin{array}{l}\text { Conventional therapy } \\
\text { (azithromycin and } \\
\text { hydroxychloroquine) and 20\% } \\
\text { albumin }\end{array}$ & Completed & NCT04405310 \\
\hline $\begin{array}{l}\text { Convalescent Plasma } \\
\text { Therapy in Severe COVID- } \\
19 \text { Infection }\end{array}$ & $\begin{array}{l}\text { Bangabandhu } \\
\text { Sheikh Mujib Medical } \\
\text { University, Dhaka, } \\
\text { Bangladesh }\end{array}$ & $\|$ & $\begin{array}{l}\text { Standard supportive } \\
\text { treatment }\end{array}$ & $\begin{array}{l}\text { Standard treatment + } \\
\text { convalescent plasma }\end{array}$ & Recruiting & NCT04403477 \\
\hline $\begin{array}{l}\text { Convalescent Plasma } \\
\text { Therapy in Patients With } \\
\text { COVID-19 }\end{array}$ & Biofarma & I & Convalescent plasma & $\mathrm{N} / \mathrm{A}$ & Completed & NCT04407208 \\
\hline $\begin{array}{l}\text { Convalescent Plasma for III } \\
\text { Patients by COVID-19 } \\
\text { (COPLASCOV19) }\end{array}$ & $\begin{array}{l}\text { Instituto de } \\
\text { Seguridad y } \\
\text { Servicios Sociales de } \\
\text { los Trabajadores del } \\
\text { Estado }\end{array}$ & $|/| \mid$ & Convalescent plasma & $\mathrm{N} / \mathrm{A}$ & Recruiting & NCT04356482 \\
\hline $\begin{array}{l}\text { COVID19-Convalescent } \\
\text { Plasma for Treating Patients } \\
\text { With Active Symptomatic } \\
\text { COVID } 19 \text { Infection (FALP- } \\
\text { COVID) (FALP-COVID) }\end{array}$ & $\begin{array}{l}\text { Fundacion Arturo } \\
\text { Lopez Perez }\end{array}$ & $\|/\|$ & Convalescent plasma & $\mathrm{N} / \mathrm{A}$ & Recruiting & NCT04384588 \\
\hline
\end{tabular}

(All information in the table are collected from https://clinicaltrials.gov).

in an individual, or the degree of transmission within a population (Hodgson et al., 2021). The comprehensive understanding of SARS-Cov-2 is unclear and evolving, thereby the outcomes for a COVID-19 vaccine are critically appraised with scientific rigor to understand their generalizability and clinical significance.

Currently, three vaccines are authorized in the United States: Pfizer-BioNTech (Name: BNT162b2), Moderna (Name: mRNA1273), and Johnson and Johnson/Janssen (Name: JNJ-78436735).

Tables 10-12 summarize the clinical trials of these vaccines for the treatment of COVID-19. Of note, people under 12 years old are not eligible to receive vaccine produced by Pfizer-BioNTech, and people under 18 years old are not eligible to receive vaccines produced by Moderna and Johnson and Johnson/Janssen. Kamidani et al. (2021) indicated that children are supposed to have the opportunity to be included in clinical trials in parallel to ongoing adult phase III clinical trials. It is because the development of a pediatric COVID-19 vaccine could prevent disease and alleviate downstream effects including social isolation and interruption in education, thereby enabling children to reengage in their world. Considering the SARS-CoV-2 variants, evidence from Polack et al. (2020) proved that BNT162b2 is $95 \%$ effective against SARS-CoV-2 infection. A 6 months of follow-up evaluation from Thomas et al. (2021) indicated that BNT162b2 has a favorable safety profile and effectively prevents COVID-19 for up to 6 months including the beta variant even though there is a gradual decline in effectiveness. Bernal et al. (Lopez Bernal et al., 2021) reported that the efficacy of the one-shot BNT162b2 vaccine is $30.7 \%$ among individuals with the delta variant, while the efficacy is $48.7 \%$ among individuals with the alpha variant. The efficacy of two shots of BNT162b2 vaccine is $88.0 \%$ among individuals with the delta variant, while the efficacy is $93.7 \%$ among individuals with the alpha variant. In other words, as CDC recommendation, vaccination against COVID-19 is the best way to stop the spread of these predominate COVID-19 strains.

Most recently, a COVID-19 vaccine booster emerged to help individuals build enough protection after vaccination. According to the information from Centers for Disease Control and Prevention (CDC, https://www.cdc.gov), individuals who have received their second dose of an mRNA COVID-19 vaccine (produced by either Pfizer-BioNTech or Moderna) for 8 months are eligible to get a booster shot. Currently, for individuals who got Johnson and Johnson/Janssen vaccine, there is not enough data to support getting an mRNA vaccine dose. 
TABLE 10 | Summary of clinical trials of BNT162b2 vaccine (produced by Pfizer-BioNTech) on COVID-19 treatment.

\begin{tabular}{|c|c|c|c|c|c|c|}
\hline Trial title & Sponsor & $\begin{array}{c}\text { Trial } \\
\text { phase }\end{array}$ & Primary intervention & $\begin{array}{l}\text { Secondary } \\
\text { intervention }\end{array}$ & Status & Identifier \\
\hline $\begin{array}{l}\text { Safety and Immunogenicity Study of } \\
\text { 20vPnC When Coadministered With } \\
\text { a Booster Dose of BNT162b2 }\end{array}$ & Pfizer & III & $\begin{array}{l}\text { An injection of } \\
\text { pneumococcal vaccine } \\
\text { (20vPnC) and of COVID-19 } \\
\text { vaccine (BNT162b2) at the } \\
\text { same visit }\end{array}$ & $\begin{array}{l}\text { An injection of pneumococcal } \\
\text { vaccine (20vPnC) alone; an } \\
\text { injection of COVID-19 } \\
\text { vaccine (BNT162b2) alone }\end{array}$ & $\begin{array}{l}\text { Active, not } \\
\text { recruiting }\end{array}$ & NCT04887948 \\
\hline $\begin{array}{l}\text { Study to Evaluate the Safety, } \\
\text { Tolerability, and Immunogenicity of } \\
\text { Multiple Formulations of BNT162b2 } \\
\text { Against COVID-19 in Healthy Adults }\end{array}$ & BioNTech SE & III & BNT162b2 & $\mathrm{N} / \mathrm{A}$ & $\begin{array}{l}\text { Active, not } \\
\text { recruiting }\end{array}$ & NCT04816669 \\
\hline $\begin{array}{l}\text { A Trial Investigating the Safety and } \\
\text { Effects of One or Two Additional } \\
\text { Doses of Comirnaty or One Dose of } \\
\text { BNT162b2s01 in BNT162-01 or } \\
\text { BNT162-04 Trial Subjects }\end{array}$ & BioNTech SE & $\|$ & BNT162b2 & N/A & Recruiting & NCT04949490 \\
\hline $\begin{array}{l}\text { Study to Evaluate the Safety and } \\
\text { Efficacy of a Booster Dose of } \\
\text { BNT162b2 Against COVID-19 in } \\
\text { Participants } \geq 16 \text { Years of Age }\end{array}$ & BioNTech SE & III & BNT162b2 & Placebo & Recruiting & NCT04955626 \\
\hline $\begin{array}{l}\text { Study to Evaluate Safety, Tolerability } \\
\text { and Immunogenicity of BNT162b2 in } \\
\text { Immunocompromised Participants } \\
\geq 2 \text { Years }\end{array}$ & BioNTech SE & $\|$ & BNT162b2 & N/A & $\begin{array}{l}\text { Not yet } \\
\text { recruiting }\end{array}$ & NCT04895982 \\
\hline Study to Evaluate the Safety, & BioNTech SE & III & BNT162b2 & Placebo & Recruiting & NCT04754594 \\
\hline
\end{tabular}

Tolerability, and Immunogenicity of

SARS CoV-2 RNA Vaccine

Candidate (BNT162b2) Against

COVID-19 in Healthy Pregnant

Women 18 Years of Age and Older

A phase 3 Study to Evaluate the

Safety, Tolerability, and

Immunogenicity of Multiple

Production Lots and Dose Levels of

BNT162b2 RNA-Based COVID-19

Vaccines Against COVID-19 in

Healthy Participants

Safety and Immunogenicity of SARS-

CoV-2 mRNA Vaccine (BNT162b2) in

Chinese Healthy Population

Third Dose of mRNA Vaccination to

Boost COVID-19 Immunity

Impact of the Immune System on

Response to Anti-Coronavirus

Disease 19 (COVID-19) Vaccine in

Allogeneic Stem Cell Recipients

(Covid Vaccin Allo)

Study to Evaluate the Safety,

Tolerability, and Immunogenicity of an

RNA Vaccine Candidate Against

COVID-19 in Healthy Japanese

Adults

Booster Dose of COVID-19 Vaccine

for Kidney Transplant Recipients

Without Adequate Humoral

Response (WHO)

Study to Describe the Safety,

Tolerability, Immunogenicity, and

Efficacy of RNA Vaccine Candidates

Against COVID-19 in Healthy

Individuals

Randomized Trial of COVID-19

Booster Vaccinations (Cobovax

Study)

BioNTech SE
The University of Hong
Kong
University of Liege

II BNT162b2

IV BNT162b2

III BNT162b2

BioNTech SE

|/II

BNT162b2

Placebo

N/A

Dafna Yahav

BioNTech SE

II/III

BNT162b2

Placebo

CoronaVac

Placebo

N/A

N/A

Kong
BNT162b2

(V)

$\begin{aligned} & \text { Active, not } \\ & \text { recruiting }\end{aligned}$
NCT04649021
Recruiting NCT05057182
Recruiting NCT04951323

Active, not

NCT04588480 recruiting

Not yet Recruiting

NCT04961229

Recruiting

NCT04368728
Not yet recruiting
NCT05057169 
TABLE 10 | (Continued) Summary of clinical trials of BNT162b2 vaccine (produced by Pfizer-BioNTech) on COVID-19 treatment.

\begin{tabular}{|c|c|c|c|c|c|c|}
\hline Trial title & Sponsor & $\begin{array}{c}\text { Trial } \\
\text { phase }\end{array}$ & Primary intervention & $\begin{array}{l}\text { Secondary } \\
\text { intervention }\end{array}$ & Status & Identifier \\
\hline $\begin{array}{l}\text { Study to Evaluate the Safety, } \\
\text { Tolerability, and Immunogenicity of an } \\
\text { RNA Vaccine Candidate Against } \\
\text { COVID-19 in Healthy Children } \\
<12 \text { Years of Age }\end{array}$ & BioNTech SE & $\|/\| \|$ & BNT162b2 & $\mathrm{N} / \mathrm{A}$ & Recruiting & NCT04816643 \\
\hline $\begin{array}{l}\text { Safety and Immunogenicity of a } \\
\text { SARS CoV } 2 \text { Multivalent RNA Vaccine } \\
\text { in Healthy Participants }\end{array}$ & BioNTech SE & $\|$ & BNT162b2 & $\mathrm{N} / \mathrm{A}$ & Recruiting & NCT05004181 \\
\hline $\begin{array}{l}\text { Third Dose Vaccination with } \\
\text { AstraZeneca or Pfizer COVID-19 } \\
\text { Vaccine Among Adults Received } \\
\text { Sinovac COVID-19 Vaccine }\end{array}$ & Mahidol University & $\|$ & BNT162b2 & ChAdOx1 AZD1222 & $\begin{array}{l}\text { Not yet } \\
\text { recruiting }\end{array}$ & NCT05049226 \\
\hline $\begin{array}{l}\text { Vaccination for Recovered Inpatients } \\
\text { With COVID-19 (VATICO) }\end{array}$ & $\begin{array}{l}\text { International Network } \\
\text { for Strategic Initiatives } \\
\text { in Global HIV Trials } \\
\text { (INSIGHT) }\end{array}$ & IV & BNT162b2 & mRNA-1273 & Recruiting & NCT04969250 \\
\hline $\begin{array}{l}\text { Mix and Match of the Second COVID- } \\
19 \text { Vaccine Dose for Safety and } \\
\text { Immunogenicity (MOSAIC) }\end{array}$ & $\begin{array}{l}\text { Canadian } \\
\text { Immunization } \\
\text { Research Network }\end{array}$ & $\|$ & BNT162b2 & mRNA-1273; ChAdOx1-S & Recruiting & NCT04894435 \\
\hline $\begin{array}{l}\text { COVID-19 Booster Vaccine in } \\
\text { Autoimmune Disease Non- } \\
\text { Responders }\end{array}$ & $\begin{array}{l}\text { National Institute of } \\
\text { Allergy and Infectious } \\
\text { Diseases (NIAID) }\end{array}$ & $\|$ & BNT162b2 & mRNA-1273; Ad26.COV2.S & Recruiting & NCT05000216 \\
\hline
\end{tabular}

(All information in the table are collected from https://clinicaltrials.gov).

\section{TRADITIONAL CHINESE MEDICINE}

Xuebijing injection (XBJ) consists of Carthamus tinctorius L., Paeonia lactiflora Pall., Ligusticum striatum DC., Salvia miltiorrhiza Bunge, and Angelica sinensis (Oliv.) Diels (Shi et al., 2017). XBJ constructs a "drug-ingredient-target-pathway" effector network to exert its therapeutic effects on COVID-19 prevention and treatment (Zheng et al., 2020). Guo et al. (2020) conducted a retrospective case-control study to determine the efficacy of XBJ on SARS-CoV-2 infection with 42 patients who received routine treatment combined with $\mathrm{XBJ}$ (observation group) and 16 patients who received routine treatment alone (control group). The results showed that patients in the observation group had a significant reduction in body temperature, improvement in CT imaging results, and shorter time in a negative nucleic acid test recovery relative to those in the control group. Also, improvement in IL-6 levels was found in the observation group compared with those in the control group, while TNF- $\alpha$ and IL-10 levels did not show significant differences between the two groups. In addition, 284 COVID-19 patients were enrolled in a multicenter, prospective, randomized controlled trial to assess the effectiveness of Lianhuaqingwen (LH) capsule (Hu et al., 2021). Compared with patients in the control group (received usual treatment alone), patients with usual treatment in combination with LH capsule treatment had higher recovery rate, shorter median time to symptom recovery, and higher rate of improvements in chest CT manifestations and clinical cure. Hence, both XBJ and LH capsules could be considered to ameliorate clinical symptoms of COVID-19. Moreover, Ni et al. reported that using Western medicine combined with Chinese traditional patent medicine Shuanghuanglian oral liquid (SHL) has expected therapeutic outcomes to COVID-19 patients, and thereby warrants further clinical trials (Ni et al., 2020b).

\section{CONCLUDING REMARKS}

For antimicrobial drugs, the acquired drug resistance should be considered and explored. The use of CQ and HCQ is controversial due to their toxicity and side effects. Moreover, lopinavir/ritonavir, umifenovir, and azithromycin appear to be promising therapeutic drugs even though some studies do not show ideal and unfavorable clinical outcomes on COVID-19 patients. The IFNs are usually used in addition to other antiviral drugs. Also, the application of IFN- $\lambda$ have more advantages than other types of IFNs in COVID-19 treatment.

TCZ, an antibody, has the ability to improve clinical responses on COVID-19 patients by suppressing inflammatory storm and, thereby, reduces mortality cases. Mepolizumab, as an antibody medication for asthma, may increase the risk of severe COVID-19 and induce a more severe course of COVID-19, particularly for COVID-19 patients with severe asthma receiving mepolizumab therapy. Sarilumab, as an FDA-approved antibody medication for rheumatoid arthritis treatment, shows clinical improvement with decreased CRP level to patients with COVID-19 disease. Furthermore, stem cell-based therapy, especially MSCs, could improve clinical symptoms and repair tissue caused by SARSCoV-2 infection. Of note, the standard protocol of MSCs therapy needs to be determined. Additionally, COVID-19 patients who received convalescent plasma transfusion in addition to standard treatment shows no clinical differences compared with those who 
TABLE 11 | Summary of clinical trials of mRNA-1273 vaccine (produced by Moderna) on COVID-19 treatment.

\begin{tabular}{|c|c|c|c|c|c|c|}
\hline Trial title & Sponsor & $\begin{array}{c}\text { Trial } \\
\text { phase }\end{array}$ & $\begin{array}{l}\text { Primary } \\
\text { intervention }\end{array}$ & $\begin{array}{l}\text { Secondary } \\
\text { intervention }\end{array}$ & Status & Identifier \\
\hline $\begin{array}{l}\text { A Study to Evaluate the Safety, Reactogenicity, } \\
\text { and Effectiveness of mRNA-1273 Vaccine in } \\
\text { Adolescents } 12 \text { to }<18 \text { Years Old to Prevent } \\
\text { COVID-19 (TeenCove) }\end{array}$ & ModernaTX, Inc & $\|/\| \|$ & mRNA-1273 & Placebo & $\begin{array}{l}\text { Active, not } \\
\text { recruiting }\end{array}$ & NCT04649151 \\
\hline $\begin{array}{l}\text { A Study to Evaluate Safety and Effectiveness of } \\
\text { mRNA-1273 COVID-19 Vaccine in Healthy } \\
\text { Children Between } 6 \text { Months of Age and Less } \\
\text { Than } 12 \text { Years of Age }\end{array}$ & ModernaTX, Inc & $\|/\| \|$ & mRNA-1273 & Placebo & Recruiting & NCT04796896 \\
\hline $\begin{array}{l}\text { A Study to Evaluate Safety and Immunogenicity } \\
\text { of mRNA-1273 Vaccine to Prevent COVID-19 in } \\
\text { Adult Organ Transplant Recipients and in Healthy } \\
\text { Adult Participants }\end{array}$ & ModernaTX, Inc & III & mRNA-1273 & $\mathrm{N} / \mathrm{A}$ & Recruiting & NCT04860297 \\
\hline $\begin{array}{l}\text { A Study to Evaluate Efficacy, Safety, and } \\
\text { Immunogenicity of mRNA-1273 Vaccine in } \\
\text { Adults Aged } 18 \text { Years and Older to Prevent } \\
\text { COVID-19 }\end{array}$ & ModernaTX, Inc & III & mRNA-1273 & Placebo & $\begin{array}{l}\text { Active, not } \\
\text { recruiting }\end{array}$ & NCT04470427 \\
\hline $\begin{array}{l}\text { Safety and Immunogenicity Study of 2019-nCoV } \\
\text { Vaccine (mRNA-1273) for Prophylaxis of SARS- } \\
\text { CoV-2 Infection (COVID-19) }\end{array}$ & $\begin{array}{l}\text { National Institute of Allergy } \\
\text { and Infectious Diseases } \\
\text { (NIAID) }\end{array}$ & 1 & mRNA-1273 & $\mathrm{N} / \mathrm{A}$ & $\begin{array}{l}\text { Active, not } \\
\text { recruiting }\end{array}$ & NCT04283461 \\
\hline $\begin{array}{l}\text { Study About the Response to the Administration } \\
\text { of a Third Dose of mRNA-1273 Vaccine (COVID- } \\
19 \text { Vaccine Moderna) in Renal Transplants With } \\
\text { Immunological Failure Initial to Vaccination (VAX- } \\
\text { TRES) }\end{array}$ & Maria Joyera Rodríguez & $\|$ & mRNA-1273 & $\mathrm{N} / \mathrm{A}$ & $\begin{array}{l}\text { Not yet } \\
\text { recruiting }\end{array}$ & NCT04930770 \\
\hline $\begin{array}{l}\text { Third Dose of COVID-19 Vaccine in LTCF } \\
\text { Residents }\end{array}$ & Mark Loeb & IV & mRNA-1273 & Prevnar13 & $\begin{array}{l}\text { Not yet } \\
\text { recruiting }\end{array}$ & NCT04978038 \\
\hline $\begin{array}{l}\text { Dose-Confirmation Study to Evaluate the Safety, } \\
\text { Reactogenicity, and Immunogenicity of mRNA- } \\
1273 \text { COVID-19 Vaccine in Adults Aged } 18 \text { Years } \\
\text { and Older }\end{array}$ & ModernaTX, Inc & $\|$ & mRNA-1273 & Placebo & $\begin{array}{l}\text { Active, not } \\
\text { recruiting }\end{array}$ & NCT04405076 \\
\hline $\begin{array}{l}\text { A Study to Evaluate Safety, Reactogenicity, and } \\
\text { Immunogenicity of mRNA-1283 and mRNA- } \\
1273 \text { Vaccines in Healthy Adults Between } 18 \text { and } \\
55 \text { Years of Age to Prevent COVID-19 }\end{array}$ & ModernaTX, Inc & I & mRNA-1273 & Placebo & $\begin{array}{l}\text { Active, not } \\
\text { recruiting }\end{array}$ & NCT04813796 \\
\hline $\begin{array}{l}\text { Immunogenecity and Safety of VaccinemRNA- } \\
1273 \text { in Elderly Volunteers (Over } 65 \text { years) } \\
\text { Compared to Younger Ones (18-45 years) } \\
\text { (CoviCompareM) }\end{array}$ & $\begin{array}{l}\text { Assistance Publique - } \\
\text { Hôpitaux de Paris }\end{array}$ & $\|$ & mRNA-1273 & $\mathrm{N} / \mathrm{A}$ & $\begin{array}{l}\text { Not yet } \\
\text { recruiting }\end{array}$ & NCT04748471 \\
\hline $\begin{array}{l}\text { A Study to Evaluate the Immunogenicity and } \\
\text { Safety of mRNA-1273.211 Vaccine for COVID- } \\
19 \text { Variants }\end{array}$ & ModernaTX, Inc & $\|/\| \|$ & mRNA-1273 & $\begin{array}{l}\text { mRNA-1273.211; } \\
\text { mRNA-1273.617.2 }\end{array}$ & $\begin{array}{l}\text { Active, not } \\
\text { recruiting }\end{array}$ & NCT04927065 \\
\hline $\begin{array}{l}\text { Safety and Immunogenicity Study of a SARS- } \\
\text { CoV-2 (COVID-19) Variant Vaccine (mRNA- } \\
\text { 1273.351) in Naïve and Previously Vaccinated } \\
\text { Adults }\end{array}$ & $\begin{array}{l}\text { National Institute of Allergy } \\
\text { and Infectious Diseases } \\
\text { (NIAID) }\end{array}$ & I & mRNA-1273 & mRNA-1273.351 & $\begin{array}{l}\text { Active, not } \\
\text { recruiting }\end{array}$ & NCT04785144 \\
\hline RECOVAC Booster Vaccination Study & $\begin{array}{l}\text { University Medical Center } \\
\text { Groningen }\end{array}$ & IV & mRNA-1273 & Ad26.COV2.S vaccine & $\begin{array}{l}\text { Not yet } \\
\text { recruiting }\end{array}$ & NCT05030974 \\
\hline $\begin{array}{l}\text { Third Dose of Moderna COVID-19 Vaccine in } \\
\text { Transplant Recipients }\end{array}$ & $\begin{array}{l}\text { University Health Network, } \\
\text { Toronto }\end{array}$ & IV & mRNA-1273 & Placebo & $\begin{array}{l}\text { Active, not } \\
\text { recruiting }\end{array}$ & NCT04885907 \\
\hline $\begin{array}{l}\text { Delayed Heterologous SARS-CoV-2 Vaccine } \\
\text { Dosing (Boost) After Receipt of EUA Vaccines }\end{array}$ & $\begin{array}{l}\text { National Institute of Allergy } \\
\text { and Infectious Diseases } \\
\text { (NIAID) }\end{array}$ & $\mid / I I$ & mRNA-1273 & $\begin{array}{l}\text { mRNA-1273.211; } \\
\text { Ad26.COV2.S; } \\
\text { BNT162b2 }\end{array}$ & Recruiting & NCT04889209 \\
\hline $\begin{array}{l}\text { SARS-CoV-2 Immune Responses After COVID- } \\
19 \text { Therapy and Subsequent Vaccine }\end{array}$ & $\begin{array}{l}\text { National Institute of Allergy } \\
\text { and Infectious Diseases } \\
\text { (NIAID) }\end{array}$ & IV & mRNA-1273 & $\mathrm{N} / \mathrm{A}$ & Recruiting & NCT04952402 \\
\hline
\end{tabular}

(All information in the table are collected from https://clinicaltrials.gov).

received standard treatment alone. Therefore, it is controversial whether it is worthwhile to assess the safety and efficacy of convalescent plasma intervention against SARS-CoV-2 infection in further randomized clinical trials.
In addition, TCMs play a critical role in ameliorating and alleviating clinical symptoms on COVID-19 patients. Also, it is known that TCMs in combination with Western medicine is a potential therapeutic strategy against SARS-CoV-2 infection. 
TABLE 12 | Summary of clinical trials of JNJ-78436735 vaccine (produced by Johnson and Johnson/Janssen) on COVID-19 treatment.

\begin{tabular}{|c|c|c|c|c|c|c|}
\hline Trial title & Sponsor & Trial phase & Primary intervention & $\begin{array}{l}\text { Secondary } \\
\text { intervention }\end{array}$ & Status & Identifier \\
\hline COVID-19 3rd Dose Vaccine in Transplant Patients & Giselle Guerr & III & BNT162b2 & JNJ-78436735 & Not yet recruiting & NCT05047640 \\
\hline
\end{tabular}

(All information in the table are collected from https://clinicaltrials.gov).

To date, remdesivir is FDA approved specifically for the treatment of COVID-19. Also, several vaccines are authorized and recommended in the United States and other countries. Most treatment regimens against the COVID-19 pandemic are controversial and remain under preclinical and clinical trials. Overall, more comprehensive information regarding each treatment regimen is uncertain and needs to be further explored.

\section{AUTHOR CONTRIBUTIONS}

All authors listed have made a substantial, direct, and intellectual contribution to the work and approved it for publication.

\section{REFERENCES}

Adamson, C. S. (2012). Protease-Mediated Maturation of HIV: Inhibitors of Protease and the Maturation Process. Mol. Biol. Int. 2012, 604261. doi:10.1155/2012/604261

Afra, S., and Matin, M. M. (2020). Potential of Mesenchymal Stem Cells for Bioengineered Blood Vessels in Comparison with Other Eligible Cell Sources. Cell Tissue Res 380 (1), 1-13. doi:10.1007/s00441-019-03161-0

Aksu, K., Yesilkaya, S., Topel, M., Turkyilmaz, S., Ercelebi, D. C., Oncul, A., et al. (2021). COVID-19 in a Patient with Severe Asthma Using Mepolizumab. Allergy Asthma Proc. 42 (2), e55-e57. doi:10.2500/aap.2021.42.200125

Alzghari, S. K., and Acuña, V. S. (2020). Supportive Treatment with Tocilizumab for COVID-19: A Systematic Review. J. Clin. Virol. 127, 104380. doi:10.1016/ j.jcv.2020.104380

Andreakos, E., and Tsiodras, S. (2020). COVID-19: Lambda Interferon against Viral Load and Hyperinflammation. EMBO Mol. Med. 12 (6), e12465. doi:10.15252/emmm.202012465

Arabi, Y. M., Alothman, A., Balkhy, H. H., Al-Dawood, A., AlJohani, S., Al Harbi, S., et al. (2018). Treatment of Middle East Respiratory Syndrome with a Combination of Lopinavir-Ritonavir and Interferon-Blb (MIRACLE Trial): Study Protocol for a Randomized Controlled Trial. Trials 19 (1), 81. doi:10.1186/s13063-017-2427-0

Azim, A., Pini, L., Khakwani, Z., Kumar, S., and Howarth, P. (2021). Severe Acute Respiratory Syndrome Coronavirus 2 Infection in Those on Mepolizumab Therapy. Ann. Allergy Asthma Immunol. 126 (4), 438-440. doi:10.1016/ j.anai.2021.01.00610.1097/COH.0000000000000658

Bakheit, A. H., Al-Hadiya, B. M., and Abd-Elgalil, A. A. (2014). Azithromycin. Profiles Drug Subst. Excip Relat. Methodol. 39, 1-40. doi:10.1016/b978-0-12800173-8.00001-5

Bevova, M. R., Netesov, S. V., and Aulchenko, Y. S. (2020). The New Coronavirus COVID-19 Infection. Mol. Gen. Microbiol. Virol. 35 (2), 53-60. doi:10.3103/ s0891416820020044

Blignaut, M., Espach, Y., van Vuuren, M., Dhanabalan, K., and Huisamen, B. (2019). Revisiting the Cardiotoxic Effect of Chloroquine. Cardiovasc. Drugs Ther. 33 (1), 1-11. doi:10.1007/s10557-018-06847-9

Bousquet, J., Jutel, M., Akdis, C. A., Klimek, L., Pfaar, O., Nadeau, K. C., et al. (2021). ARIA-EAACI Statement on Asthma and COVID-19 (June 2, 2020). Allergy 76 (3), 689-697. doi:10.1111/all.14471

\section{FUNDING}

This work was partially supported by the Second Batch of Outstanding Young Medical Talents in Ganzhou City Health System (Jiangxi, China). The author (YY) thanks the support as a teaching fellow from Department of Pharmaceutical Sciences, St. John's University (New York, United States).

\section{ACKNOWLEDGMENTS}

We thank Yangmin Chen (St. John's University) for editing the article. Thanks to all the peer reviewers and editors for their opinions and suggestions.

Caballero Bermejo, A. F., Ruiz-Antorán, B., Fernández Cruz, A., Diago Sempere, E., Callejas Díaz, A., Múñez Rubio, E., et al. (2020). Sarilumab versus Standard of Care for the Early Treatment of COVID-19 Pneumonia in Hospitalized Patients: SARTRE: a Structured Summary of a Study Protocol for a Randomised Controlled Trial. Trials 21 (1), 794. doi:10.1186/s13063-02004633-3

Cao, B., Wang, Y., Wen, D., Liu, W., Wang, J., Fan, G., et al. (2020). A Trial of Lopinavir-Ritonavir in Adults Hospitalized with Severe Covid-19. N. Engl. J. Med. 382 (19), 1787-1799. doi:10.1056/NEJMoa2001282

Cavalcanti, A. B., Zampieri, F. G., Rosa, R. G., Azevedo, L. C. P., Veiga, V. C., Avezum, A., et al. (2020). Hydroxychloroquine with or without Azithromycin in Mild-To-Moderate Covid-19. N. Engl. J. Med. 383 (21), 2041-2052. doi:10.1056/NEJMoa2019014

Chen, L., Xiong, J., Bao, L., and Shi, Y. (2020a). Convalescent Plasma as a Potential Therapy for COVID-19. Lancet Infect. Dis. 20 (4), 398-400. doi:10.1016/s14733099(20)30141-9

Chen, N., Zhou, M., Dong, X., Qu, J., Gong, F., Han, Y., et al. (2020b). Epidemiological and Clinical Characteristics of 99 Cases of 2019 Novel Coronavirus Pneumonia in Wuhan, China: a Descriptive Study. Lancet 395 (10223), 507-513. doi:10.1016/s0140-6736(20)30211-7

Chen, S., Cui, G., Peng, C., Lavin, M. F., Sun, X., Zhang, E., et al. (2018). Transplantation of Adipose-Derived Mesenchymal Stem Cells Attenuates Pulmonary Fibrosis of Silicosis via Anti-inflammatory and Anti-apoptosis Effects in Rats. Stem Cel Res Ther 9 (1), 110. doi:10.1186/s13287-0180846-9

Cheng, Y., Wong, R., Soo, Y. O., Wong, W. S., Lee, C. K., Ng, M. H., et al. (2005). Use of Convalescent Plasma Therapy in SARS Patients in Hong Kong. Eur. J. Clin. Microbiol. Infect. Dis. 24 (1), 44-46. doi:10.1007/s10096-004-1271-9

Choudhery, M. S., and Harris, D. T. (2020). Stem Cell Therapy for COVID-19: Possibilities and Challenges. Cell Biol Int 44 (11), 2182-2191. doi:10.1002/ cbin. 11440

Chu, C. M., Cheng, V. C., Hung, I. F., Wong, M. M., Chan, K. H., Chan, K. S., et al. (2004). Role of Lopinavir/ritonavir in the Treatment of SARS: Initial Virological and Clinical Findings. Thorax 59 (3), 252-256. doi:10.1136/thorax.2003.012658

Conti, P., Ronconi, G., Caraffa, A., Gallenga, C. E., Ross, R., Frydas, I., et al. (2020). Induction of Pro-inflammatory Cytokines (IL-1 and IL-6) and Lung Inflammation by Coronavirus-19 (COVI-19 or SARS-CoV-2): Antiinflammatory Strategies. J. Biol. Regul. Homeost Agents 34 (2), 327-331. doi:10.23812/conti-e 
Cvetkovic, R. S., and Goa, K. L. (2003). Lopinavir/ritonavir: a Review of its Use in the Management of HIV Infection. Drugs 63 (8), 769-802. doi:10.2165/ 00003495-200363080-00004

Della-Torre, E., Campochiaro, C., Cavalli, G., De Luca, G., Napolitano, A., La Marca, S., et al. (2020). Interleukin-6 Blockade with Sarilumab in Severe COVID-19 Pneumonia with Systemic Hyperinflammation: an Open-Label Cohort Study. Ann. Rheum. Dis. 79 (10), 1277-1285. doi:10.1136/ annrheumdis-2020-218122

Deng, L., Li, C., Zeng, Q., Liu, X., Li, X., Zhang, H., et al. (2020). Arbidol Combined with LPV/r versus LPV/r Alone against Corona Virus Disease 2019: A Retrospective Cohort Study. J. Infect. 81 (1), e1-e5. doi:10.1016/ j.jinf.2020.03.002

Du, Y., Tu, L., Zhu, P., Mu, M., Wang, R., Yang, P., et al. (2020). Clinical Features of 85 Fatal Cases of COVID-19 from Wuhan. A Retrospective Observational Study. Am. J. Respir. Crit. Care Med. 201 (11), 1372-1379. doi:10.1164/ rccm.202003-0543OC

Echeverría-Esnal, D., Martin-Ontiyuelo, C., Navarrete-Rouco, M. E., De-Antonio Cuscó, M., Ferrández, O., Horcajada, J. P., et al. (2021). Azithromycin in the Treatment of COVID-19: a Review. Expert Rev. Anti Infect. Ther. 19 (2), 147-163. doi:10.1080/14787210.2020.1813024

Eger, K., Hashimoto, S., Braunstahl, G. J., Brinke, A. T., Patberg, K. W., Beukert, A., et al. (2020). Poor Outcome of SARS-CoV-2 Infection in Patients with Severe Asthma on Biologic Therapy. Respir. Med. 177, 106287. doi:10.1016/ j.rmed.2020.106287

Ennis, D., Lee, J. K., and Pagnoux, C. (2019). Mepolizumab for the Treatment of Eosinophilic Granulomatosis with Polyangiitis. Expert Opin. Biol. Ther. 19 (7), 617-630. doi:10.1080/14712598.2019.1623875

Fu, B., Xu, X., and Wei, H. (2020). Why Tocilizumab Could Be an Effective Treatment for Severe COVID-19. J. Transl Med. 18 (1), 164. doi:10.1186/ s12967-020-02339-3

Gabay, C., Emery, P., van Vollenhoven, R., Dikranian, A., Alten, R., Pavelka, K., et al. (2013). Tocilizumab Monotherapy versus Adalimumab Monotherapy for Treatment of Rheumatoid Arthritis (ADACTA): a Randomised, Double-Blind, Controlled Phase 4 Trial. Lancet 381 (9877), 1541-1550. doi:10.1016/s01406736(13)60250-0

Gao, J., Tian, Z., and Yang, X. (2020). Breakthrough: Chloroquine Phosphate Has Shown Apparent Efficacy in Treatment of COVID-19 Associated Pneumonia in Clinical Studies. Biosci. Trends 14 (1), 72-73. doi:10.5582/bst.2020.01047

Garcia-Vicuña, R., Abad-Santos, F., González-Alvaro, I., Ramos-Lima, F., and Sanz, J. S. (2020). Subcutaneous Sarilumab in Hospitalised Patients with Moderate-Severe COVID-19 Infection Compared to the Standard of Care (SARCOVID): a Structured Summary of a Study Protocol for a Randomised Controlled Trial. Trials 21 (1), 772. doi:10.1186/s13063-020-04588-5

Gautret, P., Lagier, J. C., Parola, P., Hoang, V. T., Meddeb, L., Mailhe, M., et al. (2020). Hydroxychloroquine and Azithromycin as a Treatment of COVID-19: Results of an Open-Label Non-randomized Clinical Trial. Int. J. Antimicrob. Agents 56 (1), 105949. doi:10.1016/j.ijantimicag.2020.105949

Golchin, A., Seyedjafari, E., and Ardeshirylajimi, A. (2020). Mesenchymal Stem Cell Therapy for COVID-19: Present or Future. Stem Cel Rev Rep 16 (3), 427-433. doi:10.1007/s12015-020-09973-w

Gulati, S., Muddasani, R., Gustavo Bergerot, P., and Pal, S. K. (2021). Systemic Therapy and COVID19: Immunotherapy and Chemotherapy. Urol. Oncol. 39 (4), 213-220. doi:10.1016/j.urolonc.2020.12.022

Guo, H., Zheng, J., Huang, G., Xiang, Y., Lang, C., Li, B., et al. (2020). Xuebijing Injection in the Treatment of COVID-19: a Retrospective Case-Control Study. Ann. Palliat. Med. 9 (5), 3235-3248. doi:10.21037/apm-20-1478

Hodgson, S. H., Mansatta, K., Mallett, G., Harris, V., Emary, K. R. W., and Pollard, A. J. (2021). What Defines an Efficacious COVID-19 Vaccine? A Review of the Challenges Assessing the Clinical Efficacy of Vaccines against SARS-CoV-2. Lancet Infect. Dis. 21 (2), e26-e35. doi:10.1016/s1473-3099(20)30773-8

Holshue, M. L., DeBolt, C., Lindquist, S., Lofy, K. H., Wiesman, J., Bruce, H., et al. (2020). First Case of 2019 Novel Coronavirus in the United States. N. Engl. J. Med. 382 (10), 929-936. doi:10.1056/NEJMoa2001191

Hu, K., Guan, W. J., Bi, Y., Zhang, W., Li, L., Zhang, B., et al. (2021). Efficacy and Safety of Lianhuaqingwen Capsules, a Repurposed Chinese Herb, in Patients with Coronavirus Disease 2019: A Multicenter, Prospective, Randomized Controlled Trial. Phytomedicine 85, 153242. doi:10.1016/ j.phymed.2020.153242
Huang, C., Wang, Y., Li, X., Ren, L., Zhao, J., Hu, Y., et al. (2020a). Clinical Features of Patients Infected with 2019 Novel Coronavirus in Wuhan, China. Lancet 395 (10223), 497-506. doi:10.1016/s0140-6736(20)30183-5

Huang, M., Li, M., Xiao, F., Pang, P., Liang, J., Tang, T., et al. (2020b). Preliminary Evidence from a Multicenter Prospective Observational Study of the Safety and Efficacy of Chloroquine for the Treatment of COVID-19. Natl. Sci. Rev. 7 (9), 1428-1436. doi:10.1101/2020.04.26.20081059

Huang, M., Tang, T., Pang, P., Li, M., Ma, R., Lu, J., et al. (2020c). Treating COVID19 with Chloroquine. J. Mol. Cel Biol 12 (4), 322-325. doi:10.1093/jmcb/ mjaa014

Hung, I. F., Lung, K. C., Tso, E. Y., Liu, R., Chung, T. W., Chu, M. Y., et al. (2020). Triple Combination of Interferon Beta-1b, Lopinavir-Ritonavir, and Ribavirin in the Treatment of Patients Admitted to Hospital with COVID-19: an OpenLabel, Randomised, Phase 2 Trial. Lancet 395 (10238), 1695-1704. doi:10.1016/ s0140-6736(20)31042-4

Ibrahim, Y. F., Moussa, R. A., Bayoumi, A. M. A., and Ahmed, A. F. (2020). Tocilizumab Attenuates Acute Lung and Kidney Injuries and Improves Survival in a Rat Model of Sepsis via Down-Regulation of NF- $\mathrm{kB} / \mathrm{JNK}$ : a Possible Role of P-Glycoprotein. Inflammopharmacology 28 (1), 215-230. doi:10.1007/s10787019-00628-y

Jayaramayya, K., Mahalaxmi, I., Subramaniam, M. D., Raj, N., Dayem, A. A., Lim, K. M., et al. (2020). Immunomodulatory Effect of Mesenchymal Stem Cells and Mesenchymal Stem-Cell-Derived Exosomes for COVID-19 Treatment. BMB Rep. 53 (8), 400-412. doi:10.5483/BMBRep.2020.53.8.121

Jomah, S., Asdaq, S. M. B., and Al-Yamani, M. J. (2020). Clinical Efficacy of Antivirals against Novel Coronavirus (COVID-19): A Review. J. Infect. Public Health 13 (9), 1187-1195. doi:10.1016/j.jiph.2020.07.013

Jorgensen, S. C. J., Kebriaei, R., and Dresser, L. D. (2020). Remdesivir: Review of Pharmacology, Pre-clinical Data, and Emerging Clinical Experience for COVID-19. Pharmacotherapy 40 (7), 659-671. doi:10.1002/phar.2429

Kamidani, S., Rostad, C. A., and Anderson, E. J. (2021). COVID-19 Vaccine Development: a Pediatric Perspective. Curr. Opin. Pediatr. 33 (1), 144-151. doi:10.1097/mop.0000000000000978

Khiali, S., Rezagholizadeh, A., and Entezari-Maleki, T. (2021). A Comprehensive Review on Sarilumab in COVID-19. Expert Opin. Biol. Ther. 21 (5), 615-626. doi:10.1080/14712598.2021.1847269

Klopfenstein, T., Zayet, S., Lohse, A., Balblanc, J. C., Badie, J., Royer, P. Y., et al. (2020). Tocilizumab Therapy Reduced Intensive Care Unit Admissions And/or Mortality in COVID-19 Patients. Med. Mal Infect. 50 (5), 397-400. doi:10.1016/ j.medmal.2020.05.001

Knox, J. M., and Owens, D. W. (1966). The Chloroquine Mystery. Arch. Dermatol. 94 (2), 205-214. doi:10.1001/archderm.1966.01600260097016

Lai, S. T. (2005). Treatment of Severe Acute Respiratory Syndrome. Eur. J. Clin. Microbiol. Infect. Dis. 24 (9), 583-591. doi:10.1007/s10096-005-0004-z

Lamb, Y. N. (2020). Remdesivir: First Approval. Drugs 80 (13), 1355-1363. doi:10.1007/s40265-020-01378-w

Leeman, K. T., Pessina, P., Lee, J. H., and Kim, C. F. (2019). Mesenchymal Stem Cells Increase Alveolar Differentiation in Lung Progenitor Organoid Cultures. Sci. Rep. 9 (1), 6479. doi:10.1038/s41598-019-42819-1

Leneva, I. A., Russell, R. J., Boriskin, Y. S., and Hay, A. J. (2009). Characteristics of Arbidol-Resistant Mutants of Influenza Virus: Implications for the Mechanism of Anti-influenza Action of Arbidol. Antivir. Res 81 (2), 132-140. doi:10.1016/ j.antiviral.2008.10.009

Leng, Z., Zhu, R., Hou, W., Feng, Y., Yang, Y., Han, Q., et al. (2020). Transplantation of ACE2(-) Mesenchymal Stem Cells Improves the Outcome of Patients with COVID-19 Pneumonia. Aging Dis. 11 (2), 216-228. doi:10.14336/ad.2020.0228

Li, H., Yang, L., Liu, F. F., Ma, X. N., He, P. L., Tang, W., et al. (2020a). Overview of Therapeutic Drug Research for COVID-19 in China. Acta Pharmacol. Sin 41 (9), 1133-1140. doi:10.1038/s41401-020-0438-y

Li, L., Zhang, W., Hu, Y., Tong, X., Zheng, S., Yang, J., et al. (2020b). Effect of Convalescent Plasma Therapy on Time to Clinical Improvement in Patients with Severe and Life-Threatening COVID-19: A Randomized Clinical Trial. Jama 324 (5), 460-470. doi:10.1001/jama.2020.10044

Li, Q., Ding, X., Xia, G., Chen, H. G., Chen, F., Geng, Z., et al. (2020c). Eosinopenia and Elevated C-Reactive Protein Facilitate Triage of COVID-19 Patients in Fever Clinic: A Retrospective Case-Control Study. EClinicalMedicine 23, 100375. doi:10.1016/j.eclinm.2020.100375 
Li, Z., Niu, S., Guo, B., Gao, T., Wang, L., Wang, Y., et al. (2020d). Stem Cell Therapy for COVID-19, ARDS and Pulmonary Fibrosis. Cell Prolif 53 (12), e12939. doi:10.1111/cpr.12939

Lian, N., Xie, H., Lin, S., Huang, J., Zhao, J., and Lin, Q. (2020). Umifenovir Treatment Is Not Associated with Improved Outcomes in Patients with Coronavirus Disease 2019: a Retrospective Study. Clin. Microbiol. Infect. 26 (7), 917-921. doi:10.1016/j.cmi.2020.04.026

Lin, F. C., and Young, H. A. (2014). Interferons: Success in Anti-viral Immunotherapy. Cytokine Growth Factor. Rev. 25 (4), 369-376. doi:10.1016/ j.cytogfr.2014.07.015

Liu, X., Chen, H., Shang, Y., Zhu, H., Chen, G., Chen, Y., et al. (2020). Efficacy of Chloroquine versus Lopinavir/ritonavir in Mild/general COVID-19 Infection: a Prospective, Open-Label, Multicenter, Randomized Controlled Clinical Study. Trials 21 (1), 622. doi:10.1186/s13063-020-04478-w

Lopez Bernal, J., Andrews, N., Gower, C., Gallagher, E., Simmons, R., Thelwall, S., et al. (2021). Effectiveness of Covid-19 Vaccines against the B.1.617.2 (Delta) Variant. N. Engl. J. Med. 385 (7), 585-594. doi:10.1056/NEJMoa2108891

Luke, T. C., Kilbane, E. M., Jackson, J. L., and Hoffman, S. L. (2006). Meta-analysis: Convalescent Blood Products for Spanish Influenza Pneumonia: a Future H5N1 Treatment. Ann. Intern. Med. 145 (8), 599-609. doi:10.7326/0003-4819-145-8200610170-00139

Luo, P., Liu, Y., Qiu, L., Liu, X., Liu, D., and Li, J. (2020). Tocilizumab Treatment in COVID-19: A Single center Experience. J. Med. Virol. 92 (7), 814-818. doi:10.1002/jmv.25801

Mair-Jenkins, J., Saavedra-Campos, M., Baillie, J. K., Cleary, P., Khaw, F. M., Lim, W. S., et al. (2015). The Effectiveness of Convalescent Plasma and Hyperimmune Immunoglobulin for the Treatment of Severe Acute Respiratory Infections of Viral Etiology: a Systematic Review and Exploratory Meta-Analysis. J. Infect. Dis. 211 (1), 80-90. doi:10.1093/infdis/ jiu396

Mantlo, E., Bukreyeva, N., Maruyama, J., Paessler, S., and Huang, C. (2020). Antiviral Activities of Type I Interferons to SARS-CoV-2 Infection. Antivir. Res 179, 104811. doi:10.1016/j.antiviral.2020.104811

Meyerowitz, E. A., Vannier, A. G. L., Friesen, M. G. N., Schoenfeld, S., Gelfand, J. A., Callahan, M. V., et al. (2020). Rethinking the Role of Hydroxychloroquine in the Treatment of COVID-19. Faseb $j 34$ (5), 6027-6037. doi:10.1096/ fj.202000919

Mo, P., Xing, Y., Xiao, Y., Deng, L., Zhao, Q., Wang, H., et al. (2020). Clinical Characteristics of Refractory COVID-19 Pneumonia in Wuhan, China. Clin. Infect. Dis.. doi:10.1093/cid/ciaa270

Mo, Y., and Fisher, D. (2016). A Review of Treatment Modalities for Middle East Respiratory Syndrome. J. Antimicrob. Chemother. 71 (12), 3340-3350. doi:10.1093/jac/dkw338

Montesarchio, V., Parrela, R., Iommelli, C., Bianco, A., Manzillo, E., Fraganza, F., et al. (2020). Outcomes and Biomarker Analyses Among Patients with COVID-19 Treated with Interleukin 6 (IL-6) Receptor Antagonist Sarilumab at a Single Institution in Italy. J. Immunother. Cancer 8 (2). doi:10.1136/jitc-2020-001089

Mukherjee, M., Sehmi, R., and Nair, P. (2014). Anti-IL5 Therapy for Asthma and beyond. World Allergy Organ. J. 7 (1), 32. doi:10.1186/1939-4551-7-32

Ni, L., Chen, L., Huang, X., Han, C., Xu, J., Zhang, H., et al. (2020a). Combating COVID-19 with Integrated Traditional Chinese and Western Medicine in China. Acta Pharm. Sin B 10 (7), 1149-1162. doi:10.1016/j.apsb.2020.06.009

Ni, L., Zhou, L., Zhou, M., Zhao, J., and Wang, D. W. (2020b). Combination of Western Medicine and Chinese Traditional Patent Medicine in Treating a Family Case of COVID-19. Front. Med. 14 (2), 210-214. doi:10.1007/s11684020-0757-x

Nojomi, M., Yassin, Z., Keyvani, H., Makiani, M. J., Roham, M., Laali, A., et al. (2020). Effect of Arbidol (Umifenovir) on COVID-19: a Randomized Controlled Trial. BMC Infect. Dis. 20 (1), 954. doi:10.1186/s12879-02005698-w

Ong, S. W. X., Chiew, C. J., Ang, L. W., Mak, T. M., Cui, L., Toh, M., et al. (2021). Clinical and Virological Features of SARS-CoV-2 Variants of Concern: a Retrospective Cohort Study Comparing B.1.1.7 (Alpha), B.1.315 (Beta), and B.1.617.2 (Delta). Clin. Infect. Dis.. doi:10.1093/cid/ciab721

Oren, O., Yang, E. H., Gluckman, T. J., Michos, E. D., Blumenthal, R. S., and Gersh, B. J. (2020). Use of Chloroquine and Hydroxychloroquine in COVID-19 and Cardiovascular Implications: Understanding Safety Discrepancies to Improve
Interpretation and Design of Clinical Trials. Circ. Arrhythm Electrophysiol. 13 (6), e008688. doi:10.1161/circep.120.008688

Peng, H., Gong, T., Huang, X., Sun, X., Luo, H., Wang, W., et al. (2020). A Synergistic Role of Convalescent Plasma and Mesenchymal Stem Cells in the Treatment of Severely Ill COVID-19 Patients: a Clinical Case Report. Stem Cel Res. Ther. 11 (1), 291. doi:10.1186/s13287-020-01802-8

Polack, F. P., Thomas, S. J., Kitchin, N., Absalon, J., Gurtman, A., Lockhart, S., et al. (2020). Safety and Efficacy of the BNT162b2 mRNA Covid-19 Vaccine. N. Engl. J. Med. 383 (27), 2603-2615. doi:10.1056/NEJMoa2034577

Prokunina-Olsson, L., Alphonse, N., Dickenson, R. E., Durbin, J. E., Glenn, J. S., Hartmann, R., et al. (2020). COVID-19 and Emerging Viral Infections: The Case for Interferon Lambda. J. Exp. Med. 217 (5). doi:10.1084/jem.20200653

Pulia, M. S., Wolf, I., Schulz, L. T., Pop-Vicas, A., Schwei, R. J., and Lindenauer, P. K. (2020). COVID-19: An Emerging Threat to Antibiotic Stewardship in the Emergency Department. West. J. Emerg. Med. 21 (5), 1283-1286. doi:10.5811/ westjem.2020.7.48848

Purwati, Budiono., Rachman, B. E., Miatmoko, A., Lardo, S., ,Purnama, Y. S., Laely, M., et al. (2021). A Randomized, Double-Blind, Multicenter Clinical Study Comparing the Efficacy and Safety of a Drug Combination of Lopinavir/ Ritonavir-Azithromycin, Lopinavir/Ritonavir-Doxycycline, and Azithromycin-Hydroxychloroquine for Patients Diagnosed with Mild to Moderate COVID-19 Infections. Biochem. Res. Int. 2021, 6685921. doi:10.1155/2021/6685921

Qin, C., Zhou, L., Hu, Z., Zhang, S., Yang, S., Tao, Y., et al. (2020). Dysregulation of Immune Response in Patients with Coronavirus 2019 (COVID-19) in Wuhan, China. 71(15), 762-768.doi:10.1093/cid/ciaa248

Rawson, T. M., Moore, L. S. P., Zhu, N., Ranganathan, N., Skolimowska, K., Gilchrist, M., et al. (2020). Bacterial and Fungal Coinfection in Individuals with Coronavirus: A Rapid Review to Support COVID-19 Antimicrobial Prescribing. Clin. Infect. Dis. 71 (9), 2459-2468. doi:10.1093/cid/ciaa530

Sadeghi, S., Soudi, S., Shafiee, A., and Hashemi, S. M. (2020). Mesenchymal Stem Cell Therapies for COVID-19: Current Status and Mechanism of Action. Life Sci. 262, 118493. doi:10.1016/j.lfs.2020.118493

Salama, C., Han, J., Yau, L., Reiss, W. G., Kramer, B., Neidhart, J. D., et al. (2021). Tocilizumab in Patients Hospitalized with Covid-19 Pneumonia. N. Engl. J. Med. 384 (1), 20-30. doi:10.1056/NEJMoa2030340

Sanches, P. R. S., Charlie-Silva, I., Braz, H. L. B., Bittar, C., Freitas Calmon, M., Rahal, P., et al. (2021). Recent Advances in SARS-CoV-2 Spike Protein and RBD Mutations Comparison between New Variants Alpha (B.1.1.7, United Kingdom), Beta (B.1.351, South Africa), Gamma (P.1, Brazil) and Delta (B.1.617.2, India). J. Virus. Erad 7 (3), 100054. doi:10.1016/ j.jve.2021.100054

Sarkar, C., Mondal, M., Torequl Islam, M., Martorell, M., Docea, A. O., Maroyi, A., et al. (2020). Potential Therapeutic Options for COVID-19: Current Status, Challenges, and Future Perspectives. 11(1428)572870. doi: doi:10.3389/ fphar.2020.572870

Sheppard, M., Laskou, F., Stapleton, P. P., Hadavi, S., and Dasgupta, B. (2017). Tocilizumab (Actemra). Hum. Vaccin. Immunother. 13 (9), 1972-1988. doi:10.1080/21645515.2017.1316909

Shi, H., Hong, Y., Qian, J., Cai, X., and Chen, S. (2017). Xuebijing in the Treatment of Patients with Sepsis. Am. J. Emerg. Med. 35 (2), 285-291. doi:10.1016/ j.ajem.2016.11.007

Sieswerda, E., de Boer, M. G. J., Bonten, M. M. J., Boersma, W. G., Jonkers, R. E., Aleva, R. M., et al. (2021). Recommendations for Antibacterial Therapy in Adults with COVID-19 - an Evidence Based Guideline. Clin. Microbiol. Infect. 27 (1), 61-66. doi:10.1016/j.cmi.2020.09.041

Simonovich, V. A., Burgos Pratx, L. D., Scibona, P., Beruto, M. V., Vallone, M. G., Vázquez, C., et al. (2021). A Randomized Trial of Convalescent Plasma in Covid-19 Severe Pneumonia. N. Engl. J. Med. 384 (7), 619-629. doi:10.1056/ NEJMoa2031304

Soo, Y. O., Cheng, Y., Wong, R., Hui, D. S., Lee, C. K., Tsang, K. K., et al. (2004). Retrospective Comparison of Convalescent Plasma with Continuing HighDose Methylprednisolone Treatment in SARS Patients. Clin. Microbiol. Infect. 10 (7), 676-678. doi:10.1111/j.1469-0691.2004.00956.x

Stone, J. H., Frigault, M. J., Serling-Boyd, N. J., Fernandes, A. D., Harvey, L., Foulkes, A. S., et al. (2020). Efficacy of Tocilizumab in Patients Hospitalized with Covid-19. N. Engl. J. Med. 383 (24), 2333-2344. doi:10.1056/ NEJMoa2028836 
Stower, H. (2020). Lopinavir-ritonavir in Severe COVID-19. Nat. Med. 26 (4), 465. doi:10.1038/s41591-020-0849-9

Tchesnokov, E. P., Feng, J. Y., Porter, D. P., and Götte, M. (2019). Mechanism of Inhibition of Ebola Virus RNA-dependent RNA Polymerase by Remdesivir. Viruses 11 (4). doi:10.3390/v11040326

Thomas, S. J., Moreira, E. D., Jr., Kitchin, N., Absalon, J., Gurtman, A., Lockhart, S., et al. (2021). Safety and Efficacy of the BNT162b2 mRNA Covid-19 Vaccine through 6 Months. N. Engl. J. Med.. doi:10.1056/NEJMoa2110345

Tiberghien, P., de Lamballerie, X., Morel, P., Gallian, P., Lacombe, K., and Yazdanpanah, Y. (2020). Collecting and Evaluating Convalescent Plasma for COVID-19 Treatment: Why and How. Vox Sang 115 (6), 488-494. doi:10.1111/ vox. 12926

Verdugo-Paiva, F., Izcovich, A., Ragusa, M., and Rada, G. (2020). Lopinavirritonavir for COVID-19: A Living Systematic Review. Medwave 20 (6), e7967. doi:10.5867/medwave.2020.06.7966

Wang, M., Cao, R., Zhang, L., Yang, X., Liu, J., Xu, M., et al. (2020a). Remdesivir and Chloroquine Effectively Inhibit the Recently Emerged Novel Coronavirus (2019-nCoV) In Vitro. Cell Res 30 (3), 269-271. doi:10.1038/s41422-020$0282-0$

Wang, Y., Zhang, D., Du, G., Du, R., Zhao, J., Jin, Y., et al. (2020b). Remdesivir in Adults with Severe COVID-19: a Randomised, Double-Blind, PlaceboControlled, Multicentre Trial. Lancet 395 (10236), 1569-1578. doi:10.1016/ s0140-6736(20)31022-9

Wang, Y., and Zhu, L.-Q. (2020). Pharmaceutical Care Recommendations for Antiviral Treatments in Children with Coronavirus Disease 2019. World J. Pediatr. : WJP 16 (3), 271-274. doi:10.1007/s12519-020-00353-5

Wei, P-F. (2020a). Diagnosis and Treatment Protocol for Novel Coronavirus Pneumonia (Trial Version 7). Chin. Med. J. (Engl) 133 (9), 1087-1095. doi: $10.1097 / \mathrm{cm} 9.0000000000000819$

Wei, P-F. (2020b). Diagnosis and Treatment Protocol for Novel Coronavirus Pneumonia (Trial Version 7). Chin. Med. J. (Engl) 133 (9), 1087-1095. doi:10.1097/cm9.0000000000000819

Woelfel, R., Corman, V. M., Guggemos, W., Seilmaier, M., Zange, S., Mueller, M. A., et al. (2020). Clinical Presentation and Virological Assessment of Hospitalized Cases of Coronavirus Disease 2019 in a Travel-Associated Transmission Cluster.

Xu, X., Han, M., Li, T., Sun, W., Wang, D., Fu, B., et al. (2020). Effective Treatment of Severe COVID-19 Patients with Tocilizumab. Proc. Natl. Acad. Sci. U S A. 117 (20), 10970-10975. doi:10.1073/pnas.2005615117

Zanoni, M., Cortesi, M., Zamagni, A., and Tesei, A. (2019). The Role of Mesenchymal Stem Cells in Radiation-Induced Lung Fibrosis. Int. J. Mol. Sci. 20 (16). doi:10.3390/ijms20163876

Zhang, C., Wu, Z., Li, J. W., Zhao, H., and Wang, G. Q. (2020). Cytokine Release Syndrome in Severe COVID-19: Interleukin-6 Receptor Antagonist
Tocilizumab May Be the Key to Reduce Mortality. Int. J. Antimicrob. Agents 55 (5), 105954. doi:10.1016/j.ijantimicag.2020.105954

Zhao, J.-Y., Yan, J.-Y., and Qu, J.-M. (2020a). Interpretations of "Diagnosis and Treatment Protocol for Novel Coronavirus Pneumonia (Trial Version 7)". 133(11), 1347-1349. doi: doi:10.1097/cm9.0000000000000866

Zhao, J., Yuan, Q., Wang, H., Liu, W., Liao, X., Su, Y., et al. (2020b2019). Antibody Responses to SARS-CoV-2 in Patients with Novel Coronavirus. disease 71 (16), 2027-2034. doi:10.1093/cid/ciaa344

Zheng, W. J., Yan, Q., Ni, Y. S., Zhan, S. F., Yang, L. L., Zhuang, H. F., et al. (2020). Examining the Effector Mechanisms of Xuebijing Injection on COVID-19 Based on Network Pharmacology. BioData Min 13, 17. doi:10.1186/s13040020-00227-6

Zhou, Q., Chen, V., Shannon, C. P., Wei, X. S., Xiang, X., Wang, X., et al. (2020a). Interferon- $\mathrm{a} 2 \mathrm{~b}$ Treatment for COVID-19. Front. Immunol. 11, 1061. doi:10.3389/fimmu.2020.01061

Zhou, W., Wang, H., Yang, Y., Chen, Z. S., Zou, C., and Zhang, J. (1878). Chloroquine against Malaria, Cancers and Viral Diseases, 5832. (Electronic)).

Zhou, W., Wang, H., Yang, Y., Chen, Z. S., Zou, C., and Zhang, J. (2020b). Chloroquine against Malaria, Cancers and Viral Diseases. Drug Discov. Today 25 (11), 2012-2022. doi:10.1016/j.drudis.2020.09.010

Zhu, Z., Lu, Z., Xu, T., Chen, C., Yang, G., Zha, T., et al. (2020). Arbidol Monotherapy Is superior to Lopinavir/ritonavir in Treating COVID-19. J. Infect. 81 (1), e21-e23. doi:10.1016/j.jinf.2020.03.060

Zou, L., Dai, L., Zhang, X., Zhang, Z., and Zhang, Z. (2020). Hydroxychloroquine and Chloroquine: a Potential and Controversial Treatment for COVID-19. Arch. Pharm. Res. 43 (8), 765-772. doi:10.1007/s12272-020-01258-7

Conflict of Interest: The authors declare that the research was conducted in the absence of any commercial or financial relationships that could be construed as a potential conflict of interest.

Publisher's Note: All claims expressed in this article are solely those of the authors and do not necessarily represent those of their affiliated organizations, or those of the publisher, the editors, and the reviewers. Any product that may be evaluated in this article, or claim that may be made by its manufacturer, is not guaranteed or endorsed by the publisher.

Copyright $\odot 2021$ Zou, Yang, Dai, Xiong, Wang, Lin and Chen. This is an openaccess article distributed under the terms of the Creative Commons Attribution License (CC BY). The use, distribution or reproduction in other forums is permitted, provided the original author(s) and the copyright owner(s) are credited and that the original publication in this journal is cited, in accordance with accepted academic practice. No use, distribution or reproduction is permitted which does not comply with these terms. 